\title{
1 Evolutionary origin of sex differentiation system in insects
}

2

3 Yasuhiko Chikami ${ }^{1,2}$, Miki Okuno $^{3}$, Atsushi Toyoda ${ }^{4,5}$, Takehiko Itoh ${ }^{6}$, Teruyuki

$4 \quad \mathrm{Niimi}^{1,2 *}$

5

$6 \quad{ }^{1}$ Division of Evolutionary Developmental Biology, National Institute for Basic

7 Biology, 38 Nishigonaka, Myodaiji, Okazaki, Aichi, 444-8585, Japan

$8 \quad{ }^{2}$ Department of Basic Biology, School of Life Science, The Graduate University for

9 Advanced Studies, SOKENDAI, 38 Nishigonaka, Myodaiji, Okazaki, Aichi, 4448585, Japan

${ }^{3}$ Division of Microbiology, Department of Infectious Medicine, Kurume University

School of Medicine, 67 Asahi-machi, Kurume, Fukuoka, 830-0011, Japan

${ }^{4}$ Comparative Genomics Laboratory, National Institute of Genetics, 1111 Yata,

Mishima, Shizuoka 411-8540, Japan

${ }^{5}$ Advanced Genomics Center, National Institute of Genetics, 1111 Yata, Mishima, Shizuoka 411-8540, Japan

${ }^{6}$ School of Life Science and Technology, Tokyo Institute of Technology, 2-12-1

Ookayama, Meguro, Tokyo, 152-8550, Japan

\section{*Corresponding author:}

Teruyuki Niimi

E-mail: niimi@nibb.ac.jp

\section{This PDF file includes:}

Main Text

Figures 1 to 6 


\section{Abstract}

27 The evolution of the functionality of genes and genetic systems is a major source of animal diversity. Its best example is insect sex differentiation systems: promoting male and female differentiation (dual-functionality) or only male differentiation (single-functionality). However, the evolutionary origin of such functional diversity is largely unknown. Here, we investigate the ancestral functions of doublesex, a key factor of insect sex differentiation system, using the apterygote insect, Thermobia domestica, and reveal that its doublesex is essential for only males at the phenotypic level, but contributes to promoting female-specific vitellogenin expression in females. This functional discordance between the phenotypic and transcription-regulatory levels in $T$. domestica shows a new type of functionality of animal sex differentiation systems. Then, we examine how the sex differentiation system transited from the single-functionality to the dual-functionality in phenotypes and uncover that a conserved female-specific motif of doublesex is detected in taxa with the dualfunctional doublesex. It is estimated that the role of the sex differentiation system for

41 female phenotypes may have evolved through accumulating mutations in the protein motif structures that led to the enhancement of its transcription-regulatory function. 
44

45

46

47

\section{Introduction}

Sex is a fundamental principle in animal reproduction and is shared among almost all animals. The differences between males and females are a large source of diversity in mating systems, species, traits, and ecological dynamics in Metazoa (Darwin, 1871; Fryzell et al., 2019; Geddes and Thomson, 1889). The universality of sex suggests that sex is an ancient feature of metazoans. On the other hand, recent studies in various animals have revealed that regulatory systems for producing sex change rapidly during animal evolution (Bachtrog et al., 2014; Beukeboom and Perrin, 2014; Herpin and Schartl, 2015). For example, genes in the sex determination/sex differentiation systems are more likely to change upstream in the gene cascade than downstream (Bopp et al., 2014; Wilkins, 1995). In eutherian mammals such as mice and humans, a transcription factor called Sex-determining region $Y($ Sry) acts as a 'master regulator' of sex determination pathway, in which Sry induces expression of a transcriptional factor doublesex and mab-3 related transcriptional factor 1 (dmrtl) in males through chain reactions of transcription factors during embryogenesis (Gubbay et al., 1990; Koopman et al., 1991; Miyawaki et al., 2020; Sinclair et al., 1991). In contrast, in medaka fish, Oryzias latipes, a paralog of dmrtl, dmy (DM-domain gene on the Y chromosome) instead of Sry promotes male differentiation via a gene cascade inducing dmrtl (Matsuda et al., 2002; Nanda et al., 2002). The diversity in gene repertoires composing sex differentiation systems has also been found in arthropods (e.g., Sharma et al., 2017; Suzuki et al., 2008; Xu et al., 2017).

Diversity of sex differentiation systems has referred to differences in gene repertoires among species or populations. At present, many evolutionary scenarios 
have been proposed to explain the evolutionary transition of gene repertoires in sex differentiation systems: e.g., neo-functionalization or sub-functionalization via gene duplication (e.g., Chandler et al., 2017; Hattori et al., 2012; Hasselmann et al., 2008; Matsuda et al., 2002; Sharma et al., 2017; Yoshimoto et al., 2008), positional exchange within the cascade via feedback loops (e.g., Myosho et al. 2012; Myosho et al, 2015; Smith et al., 2009; Takehana et al., 2014), and functional shifts via accumulation of mutations in cis- or trans-elements (e.g., Kamiya et al., 2012; Sato et al., 2010) (reviewed in Beukeboom and Perrin, 2014). Currently, most of the diversity of sex differentiation systems is explained by these well-understood scenarios for changes in gene repertoires. However, recently, a difference in sex differentiation systems without swapping gene repertoires has been discovered from pterygote insects.

Pterygote insects exhibit tremendous sexual dimorphisms in the head, abdomen, wings, and so on, realizing a complex mating strategy. Most of the sexual differences are produced by a sex differentiation system that uses a transcription factor doublesex (dsx, a homolog of dmrt1) as a bottom factor (Kopp, 2012; Verhulst and van de Zande, 2015). Studies on Aparaglossata (holometabolan insects excluding Hymenoptera) have shown that $d s x$ promotes both male and female differentiation via the sex-specific splicing (Burtis and Baker1989; Gotoh et al., 2016; Hildreth, 1964; Ito et al., 2013; Kijimoto et al., 2012; Ohbayashi et al., 2001; Shukla and Palli, 2012; $X u$ et al., 2017). Recent studies showed that $d s x$ promotes only male differentiation in several hemimetabolan and hymenopteran insects, even though $d s x$ has sex-specific isoforms (Mine et al., 2017; Takahashi et al., 2021; Wexler et al., 2015; Zhuo et al., 2018). Thus, there is a difference in outputs in the sex differentiation systems in 
92 insects: promoting only male differentiation (single-functionality) or both male and

93 female differentiation (dual-functionality). It is suggested that the output of the insect

94 sex differentiation systems transited from the single-functionality to the dual-

95 functionality (Wexler et al., 2019). However, it remains largely unclear how the

96 difference in the output evolved independently of changes in gene repertoires and

97 what drove such a transition (Hopkins and Kopp, 2021). Also, it is unidentified the

98 ancestral roles of $d s x$ isoforms in insects.

The evolutionary origin of the sex differentiation system in insects is

ambiguous by the inability to estimate the status of the common ancestor of Insecta.

101 All of the previous studies examining the $d s x$ functionality have been limited to

pterygote insects or crustaceans and chelicerates. In chelicerates and crustaceans, $d s x$

Pomerantz et al., 2015). We are currently forced to compare the status of crustaceans with that of pterygote insects, resulting in a large gap in phylogenetic mapping.

Furthermore, previous reports of the single-functionality have been based mainly on the sexual differences acquired or complicated by each taxon in hemimetabolan insects. Therefore, it remains possible that the single-functionality reported so far results in a secondary loss of roles in female differentiation. that retain the sexual traits of the common ancestor of Insecta and that emerged between the crustaceans and Pterygota. To this end, we focused on the firebrat

113 Thermobia domestica (Zygentoma) belonging to Zygentoma, the sister group of

114 Pterygota (Misof et al., 2014). The sexual traits of T. domestica are restricted to the 
mirror the ancestral state of insects (Beutel et al., 2017; Boudinot, 2018; Emeljanov,

117 2014; Kristensen, 1975; Matsuda, 1976). Here, to examine the exon-intron structure

118 of $d s x$, we decoded the genome of $T$. domestica. Then, we developed the technology

119 to effectively inhibit gene function during postembryonic development and regulation, and compared them with other insects.

\section{Results}

\section{Molecular evolution of Doublesex in Pancrustacea}

First, we examined the relationship among $d s x$ homologs in animals (Figure1-

figure supplement 1 , Table 1) and revealed that the pancrustacean transcription factor melanogaster. We thus named the gene in Insect Dsx clade $2 d s x$-like to distinguish it repeatedly in pterygote taxa. This fact supports that $T$. domestica retains the ancestral 

expression and function of $d s x$-like.

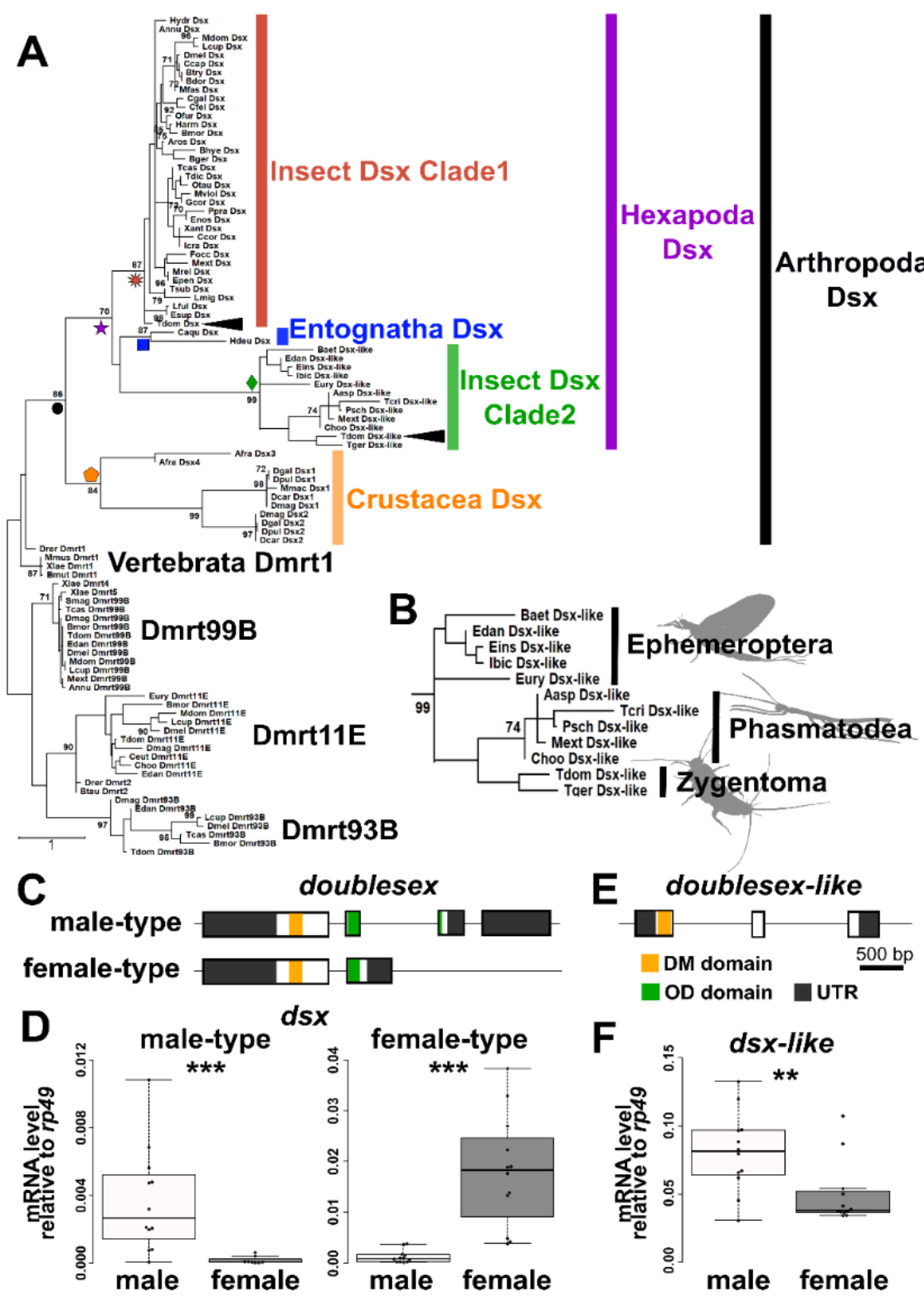

Figure 1. Molecular evolution and features of Doublesex in Thermobia domestica. (A to B) Molecular phylogeny of Doublesex and Mab-3 related transcriptional factors (DMRT) (A) and enlarged view of insect Dsx Clade2 (dsx-like clade) (B). The numerical value on each node is the bootstrap supporting value. Bootstrap values $<70$ are not shown. The node of each clade is indicated by colored shapes: black circle, Arthropoda Dsx; orange pentagon, Crustacea Dsx; purple star, Hexapoda Dsx; red sunburst, Insect Dsx Clade1; green diamond, Insect Dsx Clade2; blue square, Entognatha Dsx. (C to F) Molecular features of $d s x$ (C and D) and $d s x$-like (E and F). $(\mathrm{C}$ and $\mathrm{E})$ indicate exon-intron structures of $d s x$ and $d s x$-like, respectively. (D and F) show mRNA expression levels of $d s x$ and $d s x$-like, respectively. Each plot is a value of an individual. Sample size is listed in Table 2. Results of Brunner-Munzel tests are indicated by asterisks: $* * P<0.01$; $* * * P<0.001$ and are described in Table 2 . 


\section{Sex-specific splicing regulation of doublesex in Thermobia domestica}

We detected two major isoforms of $d s x$ of $T$. domestica (Figure 1C). Mapping these sequences to our genome data showed that the longer (951 bp) and shorter (756 bp) isoforms. Both isoforms shared a Doublesex and Mab-3 (DM) domain-containing exon, but differed in the 3'-terminus. The longer isoform was expressed at 40 -fold higher levels in males than in females in the fat body. The shorter isoform was expressed in the fat body 18 times higher in females than in males (Figure 1D). We named thus the longer and shorter isoforms $d s x$ male-type and $d s x$ female-type, respectively. $d s x$-like was expressed two-fold more highly in males than in females (Figure 1F) but had no isoform (Figure 1E). Thus, $d s x$ was regulated by a sex-specific splicing, whereas $d s x$-like was not under splicing control.

Before RNA interference (RNAi) analyses, we confirmed that expression levels of $d s x$ and $d s x$-like mRNA were significantly reduced in $d s x$ and $d s x$-like RNAi males and females. (Figure 1-figure supplement 3A and Table 2; see Materials and Methods section).

\section{Single-functionality of doublesex for phenotypic sex differentiation in $T$.}

\section{domestica}

The sexual traits in $T$. domestica are the male penis and the female ovipositor (Figure 2A-D).

In T. domestica males, the penis is an unpaired appendix on the abdomen segment IX (Matsuda, 1976). The penis was sub-segmented into two parts. There were many setae on the left and the right side of the distal tips (Figure 2E, Figure2figure supplement 1E). The surface of the penis had a reticulated pattern (Figure 2E, Figure2-figure supplement 1C, E). This simple penial structure was presumably gained at the last common ancestor of Ectognatha (Boudinot, 2018). 

(gonapophysis) and is derived from the retracted vesicles on the abdomen VIII and IX (Emeljanov, 2014; Matsuda, 1976). This ovipositor is an autapomorphy of Ectognatha

were the ventral part of the ovipositor and a paired structure. The gonapophyses on the abdomen IX (valvula II) were the dorsal side of the ovipositor and were united to form an unpaired structure (Figure 2-figure supplement 2B). The distal tip of the valvula II remained a paired structure and possessed dense setae (Figure 2-figure supplement 2A). The valvula I was shorter than the valvula II (Figure 2-figure

The valvula I and II were connected through a tongue-and-groove structure

(olistheter). The olistheter consisted of an aulax ("groove") on the valvula I and a rhachis ("tongue") on the valvula II (Figure 2-figure supplement 2B). Within the inner surface (i.e., the side of the egg cavity) of the ovipositor had a thin and singlelayered cuticle. the penis (Figure 2C, Figure2-figure supplement 1A). This tubular organ consisted of and the ejaculatory duct. The outer one had a lot of setae on its tip (Figure 2E,

199 Figure2-figure supplement 1C, E). Thus, the inner pair was similar to the valvula I of the female ovipositor and the outer one was similar to the valvula II. These features indicated that the tubular organ in the $d s x$ RNAi males was parallel to the female 
males. In contrast, the $d s x$-like males possessed a penis the same as that of the control insects. genes, the external genital organ was the same as the ovipositor of the control females that described in the above section (Figure 2D, F, Figure 2-figure supplement 1B, D,

210 from the ovipositor of the control ones.
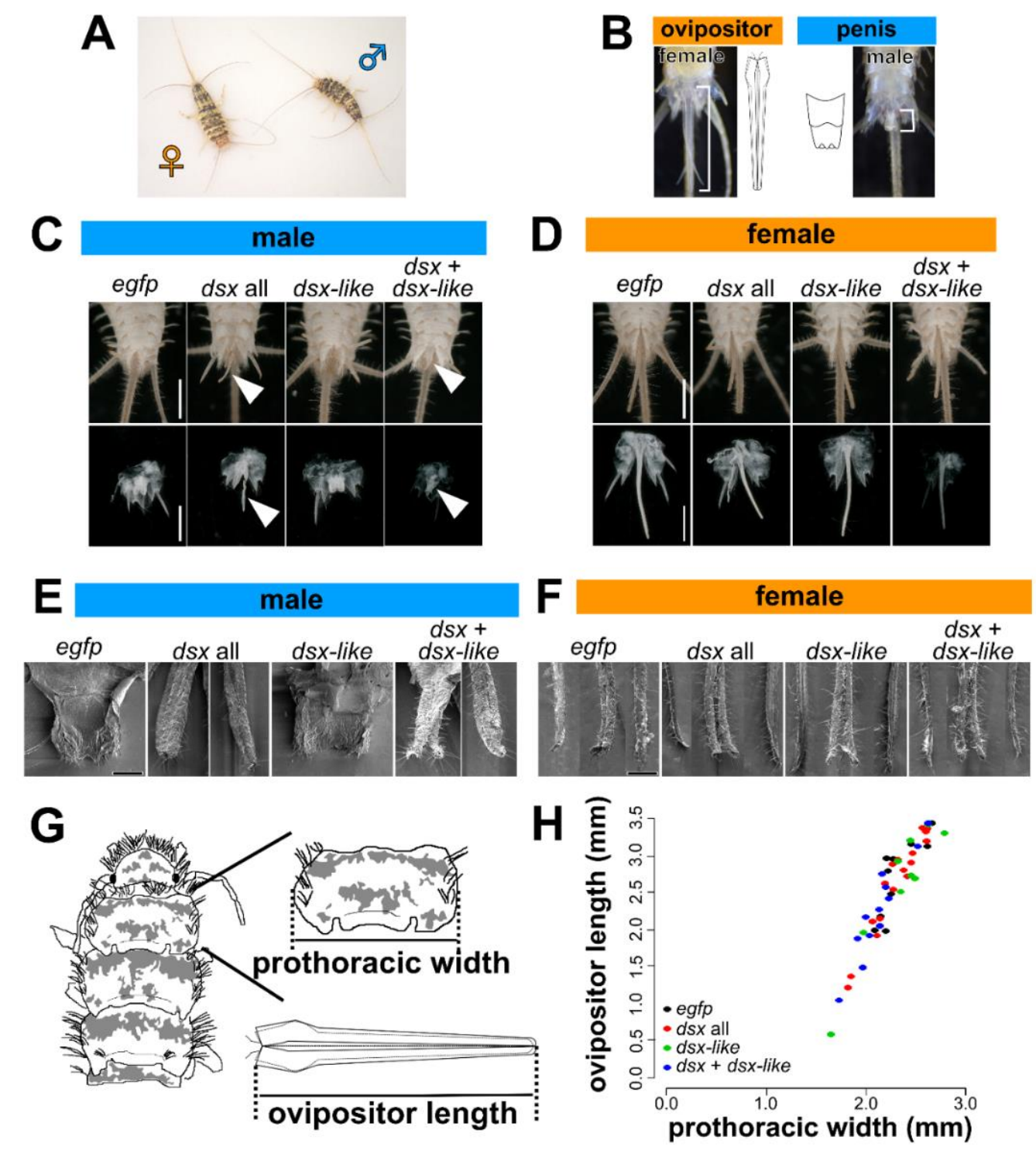

Figure 2. Function of Doublesex in sexually dimorphic traits in Thermobia domestica. (A) A pair of T. domestica. The female looks much the same as the male. 
(B) Sexually dimorphic traits of T. domestica. Females possess an ovipositor and males have a penis. (C to F) Phenotypes of $d s x$ and $d s x$-like RNA interference (RNAi) individuals. Light microscopic image (C and $\mathrm{D})$ and scanning electron microscopic image (E and F). Scales: $1 \mathrm{~cm}$ (C and D); $50 \mu \mathrm{m}$ (E and F). (G to H) Effect of $d s x$ and dsx-like RNAi on the growth of the ovipositor. The ovipositor length was measured and is plotted with prothoracic width, an indicator of body size. The measurement scheme $(\mathrm{G})$ and scatter plots $(\mathrm{H})$. Each plot in $(\mathrm{H})$ indicates a value of each individual. Sample size of $(\mathrm{H})$ is listed in Table 4. Results of the generalized linear model analysis are listed in Table 4.

\section{No evidence for the effects of doublesex on female phenotypes in T. domestica}

To investigate whether $d s x$ in $T$. domestica females has functions other than female differentiation for phenotypes, we examined its role in the growth and maintenance of female organs (Figure 2G). We did not detect a significant difference in ovipositor length and prothoracic width, an indicator of body size, between the controls and the $d s x$ and $d s x$-like RNA females (Figures 2H, Figure 2-figure supplement 3, Figure2-figure supplement 4 and Table 4).

We then examined the effects of $d s x$ on gonads, reproductive systems, and gametogenesis in $T$. domestica.

In males of T. domestica, a pair of testes was consisted of some testicular follicles (Figure 3A). Each testicular follicle was connected to the vas deferens via the vas efferens (Figure 3-figure supplement 1B). The seminal vesicle lay between the vas deferens and the ejaculatory duct. A pair of the ejaculatory ducts was associated with each other in the front of the gonopore in the penis (Figure 3C). The testicular follicles were a bean-like shape and the seminal vesicles were a bean pod-like shape. In the testicular follicle, the spermatogonia was in the antero-most part (Figures 3A). The primary and secondary spermatocytes lay in the middle part (Figures 3A). In the posterior part of the testicular follicle, there were some sperm bundles (Figures 3A). The wall of the testicular follicle consisted of a single flattened epithelial layer. 
RNAi males (Figure 3A and C). In $d s x$ and both genes RNAi males, the seminal vesicles were round in shape. The vas efferens was filled with the sperm (Figure 3-

of the testicular follicles or spermatogenesis between the RNAi and control males.

247 The male reproductive system and spermatogenesis showed no visible difference

248 between $d s x$ female-type and $d s x$-like RNAi females and the control ones.

In females of $T$. domestica, each ovary consists of five ovarioles and was

The lateral oviduct was connected to the common oviduct and subsequently opened at the gonopore in the valvula I. There was no vagina between the gonopore and the oviduct. The spermatheca was located on the branch point of the common oviduct along the midline (Figure 3-figure supplement 1A). The spermatheca was divided into two parts: anterior and posterior (Figure 3-figure supplement 2). The anterior part consisted of a pseudostratified layer of the columnar epithelial cells that were secretory. The posterior part was surrounded by a single layer of epithelial cells. The ovariole was panoistic-type and was composed of two parts: the germarium and the vitellarium (Figure 3A, B). The germarium contained many oogonia and young oocytes. The vitellarium had previtellogenic and vitellogenic oocytes. The oocytes in the vitellarium were surrounded by a single layer of follicle cells. There were pedicel cells in the terminal of the ovariole. The previtellogenic oocyte had a large germinal vesicle and basophilic cytoplasm. The vitellogenic oocyte was elongated along the anterior-posterior axis of the ovariole and had eosinophilic cytoplasm. Many 
267 oocytes. The follicle cells were flattened and columnar in shape in the

268 previtellogenesis and the vitellogenesis.

We observed the above features of the reproductive system in $d s x$ or $d s x$-like

270 RNAi females (Figures 3A, Figure 3-figure supplement 1, Figure 3-figure

271 supplement 2). We could not detect differences in the female reproductive system or

272 oogenesis between the RNAi females and the controls. This result suggests that the

$273 d s x$ and $d s x$-like have no function in the formation of female traits and gametogenesis

274 at the tissue and cellular level.

Also, we were not able to detect any differences in the oocyte number and size between the controls and RNAi females (Figures 3B, Figure3-figure supplement 3

277 and Table 4). However, the seminal vesicle in males became round in shape in the $d s x$

278 RNAi males in contrast to the bean pod-like shape observed in the control males

279 (Figures 3C, Figure3-figure supplement 1). We detected a significant reduction of the number of sperms within the seminal vesicle in $d s x$ RNAi males (Figure 3D and Table 5). $d s x$ thus contributed to the development of the reproductive system and gametes in males, but not in females, of T. domestica. 

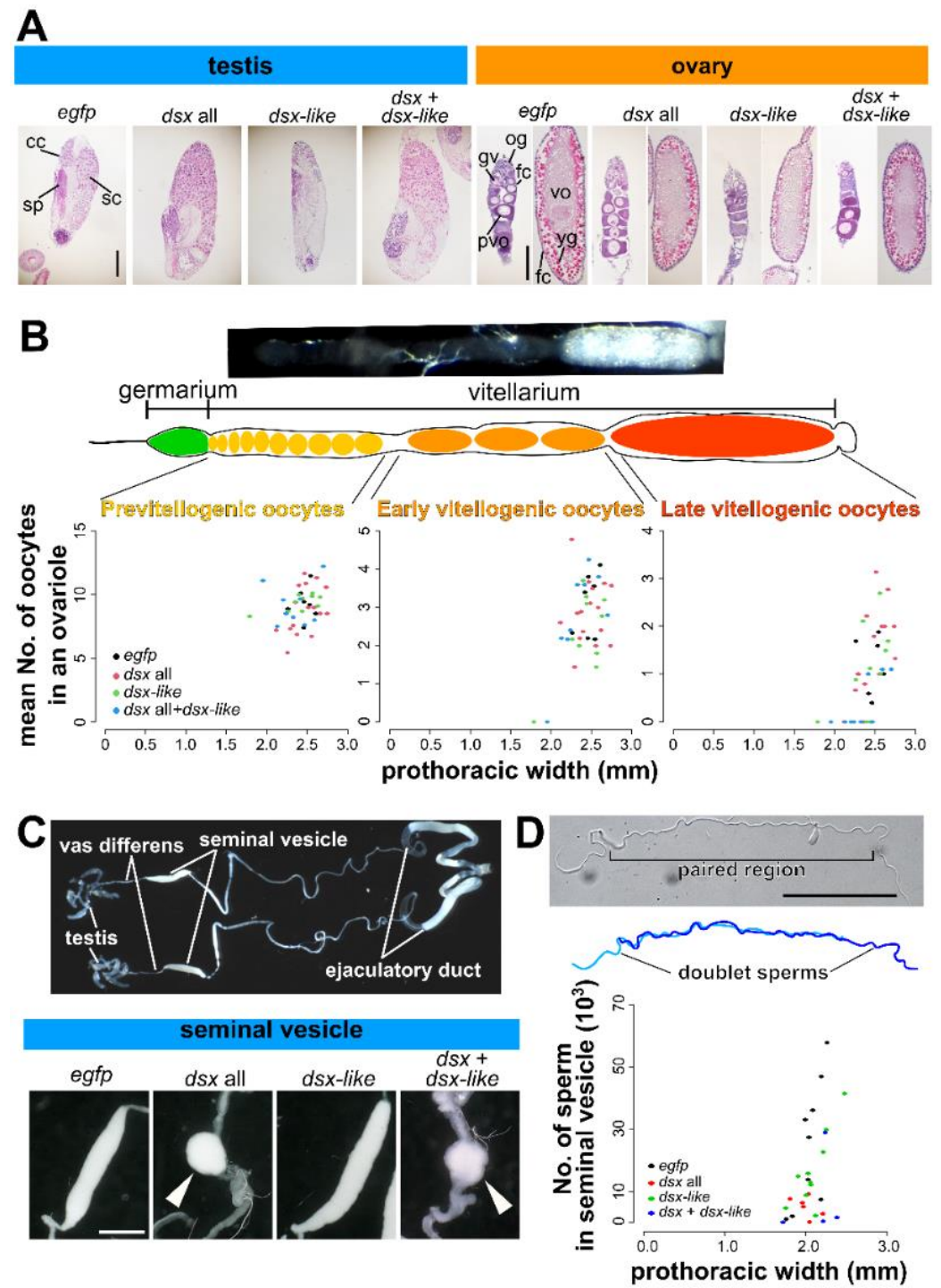

Figure 3. Function of doublesex in reproductive systems and fecundity. (A) Effects of $d s x$ and $d s x$-like RNAi on gonad morphology and gametogenesis. In images of the ovary, the left and right panel in each treatment show germarium/previtellogenesis and vitellogenesis, respectively. cc, cystocyte; fc, follicle cell; gv, germinal vesicle; og, oogonia; pvo, previtellogenic oocyte; sc, spermatocyte; sp, sperm; yg, yolk granule; vo, vitellogenic oocyte. (B) The effect of $d s x$ and $d s x$-like RNAi on oocyte number in each oogenetic stage. The upper panels are images of an ovariole in $T$. domestica. The lower panel shows scatter plots of oocyte numbers and prothoracic width. Results of the generalized linear model analysis are in Tables 4 (female) and 5 (male). (C) The effect of $d s x$ and $d s x$-like RNAi on the seminal vesicle. The upper panel is a gross image of the male reproductive system. The lower one shows the phenotype of each treatment. (D) The effect of $d s x$ and $d s x$-like RNAi on sperm number in seminal vesicles. The upper panels are images of sperm in T. domestica. The sperm of $T$. domestica is usually paired with other sperm. The lower panel shows a scatter plot of sperm numbers by prothoracic width. Scales: $50 \mu \mathrm{m}$ (A and C); 10 $\mu \mathrm{m}$ (D). Sample size are also listed in Tables 4 (D) and 5 (C). 


\section{Cryptic role of doublesex for female-specific transcripts in T. domestica}

Previous studies in Hemimetabola (Takahashi et al., 2021; Wexler et al., 2015; Zhuo et al., 2018), and our results in Zygentoma show that $d s x$ is not essential for the formation of female phenotypes in non-Holometabola. In contrast, considering the fact that the $d s x$ female-specific isoform retains ORFs in non-Holometabola, there is a still possibility that $d s x$ may have some function in non-holometabolan females. To investigate this functionality, we focused on the effect of $d s x$ on female-specific gene expression.

We focused on the vitellogenin ( $v t g$ ) gene, one of the major egg yolk proteins, which is specifically expressed in females of Bilateria (Byrne et al., 1989; Hayward et al., 2010). In the Holometabola, $d s x$ promotes $v t g$ mRNA expression in females and represses it in males (Shukla and Palli, 2012; Suzuki et al., 2003; Thongsaiklaing et al., 2018). Our RNA-seq analysis showed that levels of the three vtg mRNAs in $T$. domestica were more than 10000-fold higher in females than in males (Figure 4A-C). We found that the $v \operatorname{tg}$ mRNAs were expressed at 40-100-fold higher levels in $d s x$ RNAi males than in the control males (Figure 4D and Table 2). Notably, the $d s x$ RNAi females produced around half the amount of $v$ tg mRNA as the controls. The $d s x$-like RNAi and a double-knockdown of $d s x$ and $d s x$-like also significantly reduced the expression of $v t g$ in females (Figure 4E and Table 2).

This result is the first case that $d s x$ can promote female-specific vitellogenin expression in non-holometabolan species, even though it does not affect female phenotypes such as the oocyte size and number. This finding suggests that it has opposite functionality between males and females in T. domestica at the generegulatory level. 

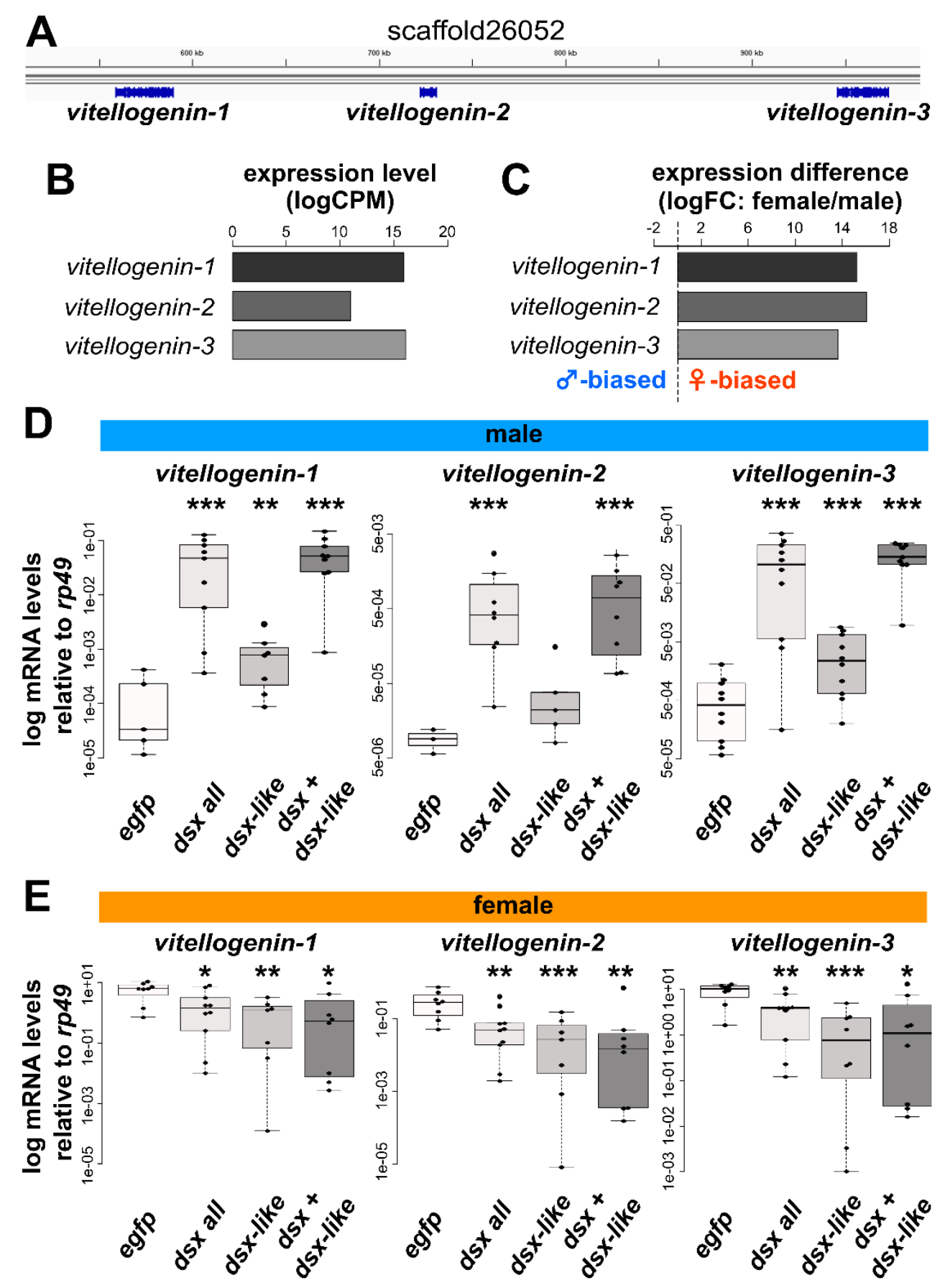

Figure 4. Function of doublesex in vitellogenin gene expression. (A to C) Features of vitellogenin (vtg) genes of Thermobia domestica. An image of the vtg gene locus in an Integrated Genome Viewer (A). The $v t g$ genes are highly expressed in females (B and C). The source data of B and C are provided as Figure4-source data 1. (D and E) Effect of $d s x$ and $d s x$-like RNAi on $v t g$ genes' expression in males (D) and females (E). The decreases were about $2 / 5-1 / 5,1 / 10-3 / 50$, and 1/9-1/20 in $d s x$, dsx-like, and both the genes RNAi females. The mRNA expression levels are shown as logarithmic scales. Each plot represents an individual. Sample sizes are listed in Table 2 (C and D). Results of Brunner-Munzel tests are indicated by asterisks: $* P<0.05$; $* * P<$ 0.01 ; *** $P<0.001$ and is also described in Table $2 . P>0.05$ is not shown. 


\section{Differences of doublesex sequences between single- and dual-functional species}

Genes can gain new functions due to gene duplication, co-factor function, changes in cis- or trans-region (Carroll, 2005; Ganfornina and Sánchez, 1999; Mann and Carroll, 2002), or acquiring new exons. $d s x$ paralog (dsx-like) found in this study did not contribute to female phenotypes (Figure 2 and 3). The female and male isoforms of $d s x$ share the same DNA-binding domain, and intersex, a co-factor gene of $d s x$, contributes to the formation of female traits in Nilaparvata lugens (Zhang et $a l ., 2021)$, which has the single-functional $d s x$. These facts indicate that the gene duplication, neo-functionalization of co-factors, and changes in cis-regulatory elements are not likely to contribute to the evolution of the dual-functionality. Thus, we explored the remaining possibilities: novel exons or trans-regions.

We found that there are alternative splice types in $T$. domestica, which has an alternative 5' splice site, and in Pterygote insects, which have a mutually exclusive exon, but did not find any differences of exon structure between species with singlefunctionality of $d s x$, and those with dual-functionality (Figure 5A).

We finally discovered amino acid sequences in the female-specific region that differed between taxa with single- and dual-functionality of $d s x . d s x$ isoforms are sexually different in the OD domain. This domain was divided into common, femalespecific, and male-specific regions. Our multiple alignment analysis revealed that the female-specific region was highly conserved among the taxa with dual-functionality of $d s x$, but not among those with single functionality (Figures 5B, Figure 5-figure supplement 1). In contrast, the male-specific region was not highly conserved among the taxa with dual-functional $d s x$ (Figure 5-figure supplement 2). 

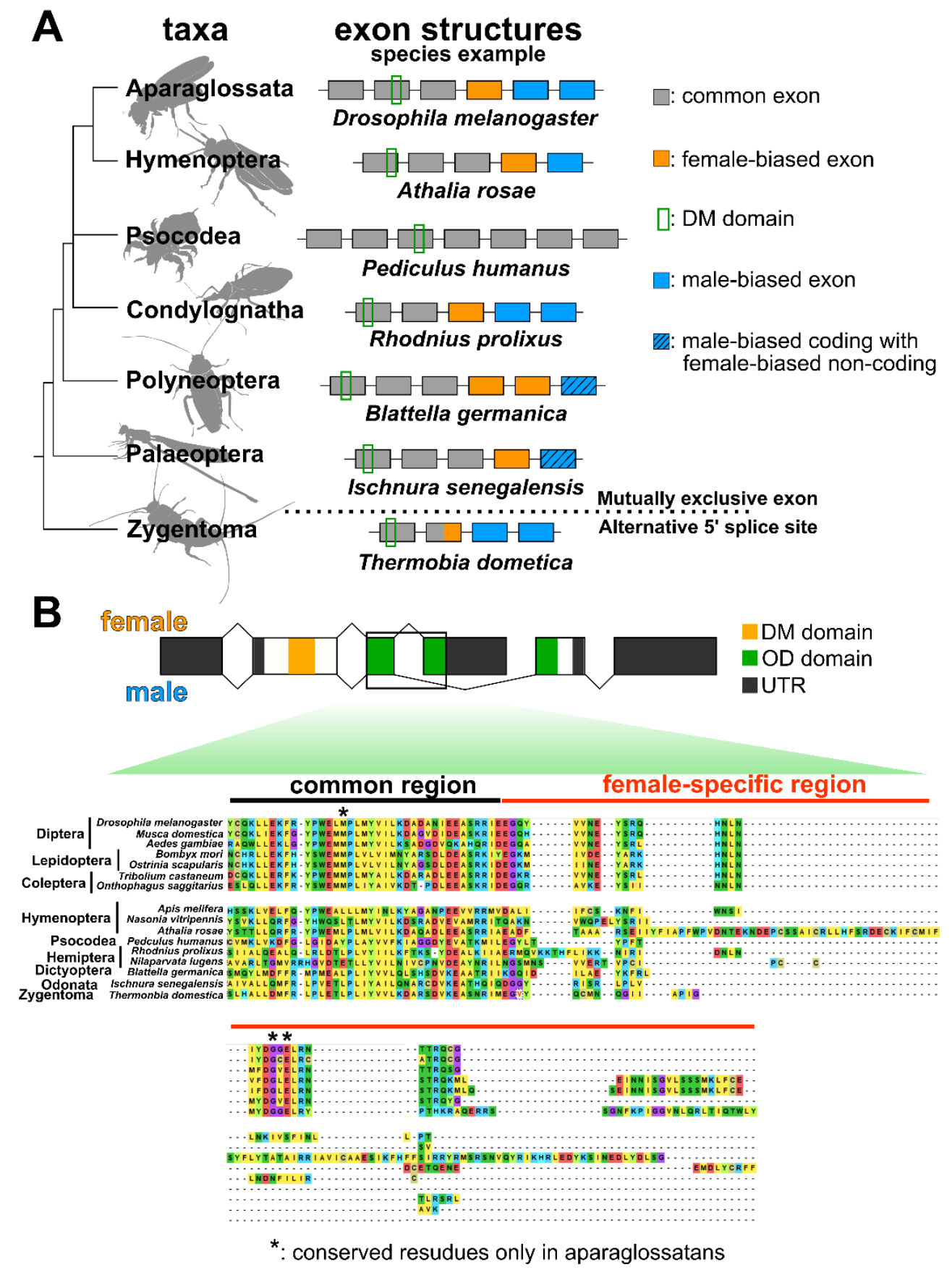

Figure 5. Comparisons of molecular features in doublesex among insect taxa. (A) Exon structure of $d s x$ among insect taxa. The coding region of $d s x$ is shown. The phylogenetic relationship is that of Misof et al. (2014) (B) amino acid sequence of Dsx among insect taxa. The upper image shows the $d s x$ structure of Drosophila melanogaster. Asterisks indicate conserved residues in Aparaglossata. 


\section{Discussion}

\section{A novel type of the output in the sex differentiation system}

We show that the $d s x$ of Thermobia domestica is essential for producing male phenotypes, but does not contribute to female phenotypes. In contrast to the phenotypes, this study showed that the female-specific vitellogenin genes are slightly promoted by $d s x$ in $T$. domestica females. These facts indicate that $d s x$ in $T$. domestica has an opposite transcription-regulatory function in males and females. Therefore, in T. domestica, $d s x$ contributes only to male differentiation at the phenotypic level, but affects both sexes at the transcription-regulatory level (seemingly useless nature). There have been two known types of outputs of the insect sex differentiation system: one that can regulate feminization via both transcription-regulation and phenotypes, and one that cannot. The former is found in Diptera, Lepidoptera, and Coleoptera (e.g., Luo and Baker, 2015; Suzuki et al., 2003; Shukla and Palli, 2012), the latter in Dictyoptera and Hemimetabola (Wexler et al., 2019; Zhuo et al., 2018). In some species, such as the dung beetle Onthophagus taurus, $d s x$ contributes only to male trait formation in some tissues (Ledón-Rettig et al., 2017). In these species, $d s x$ is also responsible for producing traits of both sexes in other tissues. Therefore, it is likely that the former type is the primary capability of the sex differentiation systems in these species and that the function for promoting female differentiation may tissuespecifically become silent. In contrast, the seemingly useless nature of $d s x$ for females in T. domestica is a third type of the insect sex differentiation system (Figure 6A). This third type indicates that phenotypic and transcription-regulatory levels do not necessarily coincide in the output of sex differentiation systems. 

have DMRT family transcription factors as bottom factors that are responsible for promoting male differentiation (Kato et al., 2011; Kopp, 2012; Raymond et al., 1998; capable of contributing to 1) only masculinization (crustaceans, nematodes, vertebrates, Hemiptera, and Dictyoptera), 2) both masculinization and feminization domestica).

On the origin of the sex-specific splicing of doublesex common ancestor of Dicondylia (Zygentoma + Pterygota) (Figure 6A).

\section{On the origin of the role of the insect sex differentiation system for females}


414 been proposed to map the characteristics of each hierarchical level separately on a

415 phylogenetic tree (c.f., Abouheif, 1999).

\section{A}

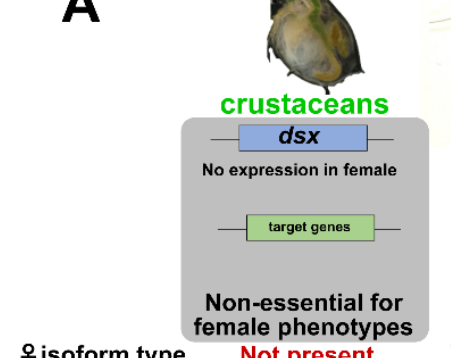

우 isoform type male phenotypes

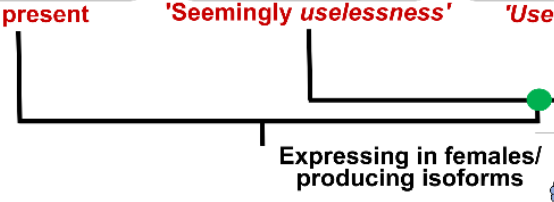

\section{B 'Parallel foundation' model}

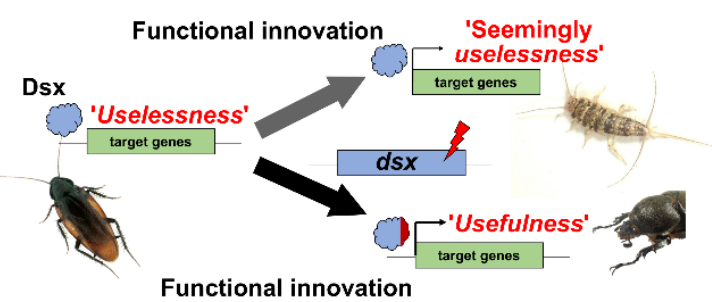

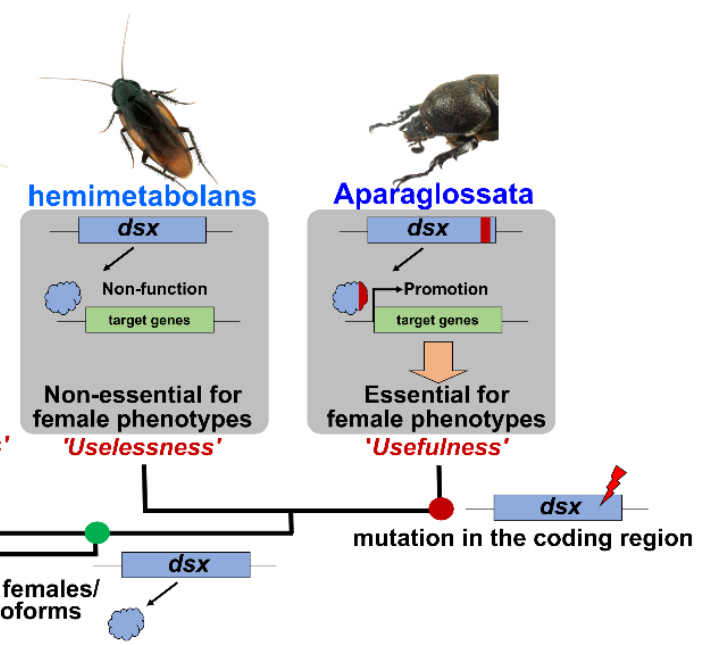

\section{C'Usefulness of uselessness' model}

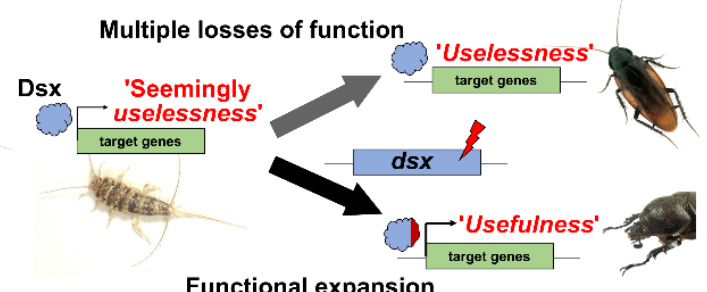

Figure 6. Evolutionary transition of outputs of the insect sex differentiation system. (A) phylogenetic mapping of functionality of $d s x$ for females. crustaceans: Kato et al. (2011); Zygentoma: this study; hemimetabolans: Wexler et al. (2019), Zhuo et al. (2018); Aparaglossata: e.g., Shukla and Palli (2012), Suzuki et al. (2003). (B) 'Parallel foundation' model. (C) 'Usefulness of useless' model.

At the phenotypic level, previous studies have focused on taxon-specific or highly complex sex differences, leaving open the possibility of a secondary loss of function of $d s x$ for females. However, the single-functionality of $d s x$ even in $T$. domestica, which has an ancestral, simple sex difference, supports a single origin for $d s x$ single-functionality. Based on a recent phylogenetic hypothesis (Beutel et al., 2017; Misof et al., 2014), the transition from the single- to dual-functionality is estimated to have occurred in the common ancestor of Aparaglossata (holometabolan 
431 insects excluding Hymenoptera) (Figure 6A). At the phenotypic level, our findings

432 ensure the evolutionary model by Wexler et al. (2019) that $d s x$ initially acquired sex-

433 specific isoforms and later became essential for female differentiation. ancestor of Dicondylia already possessed the sexual dimorphic transcriptional control of $d s x$. In this case, it is inferred that the transcription-promoting function of femalespecific genes was secondarily lost in hemimetabolan insects. Alternatively, it is possible that the common ancestor of the Dicondylia had also the single-functionality at the level of transcriptional regulation and that Zygentoma and Aparaglossata independently acquired the ability to promote transcription in females. have found differences in the sequence of the female-specific region of $d s x$ between phenotypically single-functional and dual-functional taxa. This region is located in the oligomerization (OD) domain, interacts with transcription factors (An et al., 1995;

447 transcriptional mediators such as intersex which is essential for female differentiation 448 (Gotoh et al., 2016; Morita et al., 2019; Xu et al., 2019; Yang et al., 2008). Studies in Blattella germanica described low conservation of the OD domain (Wexler et al., 2019). Baral et al. (2019) also reported that the rate of non-synonymous substitutions

451 in the female-specific region is low in Aparaglossata and high in Hymenoptera.

452 However, the evolutionary significance of this region has been unclear. Our result 453 suggests that the accumulation of mutations in female-specific regions has led to the 454 female-differentiating functions at the phenotypic level (Figure 6). It was theoretically 
in coding regions (Keren et al., 2010). The functional evolution of $d s x$ in insects may

457 fit this prediction.

\section{Evolutionary scenarios for the transition of the output of the sex differentiation} system

In conclusion, we propose two alternative scenarios for the transition of the outputs of the insect sex differentiation system.

"Parallel foundation" hypothesis (Figure 6B): $d s x$ has independently acquired the function for promoting female transcription in Zygentoma and Aparaglossata, and also gained the entirely novel role in phenotypic differentiation in females through the accumulation of coding mutations in Aparaglossata. This is the hypothesis that a useful functionality has arisen from a completely useless functionality.

"Usefulness of uselessness" hypothesis (Figure 6C): $d s x$, through the accumulation of mutations in its coding region, enhanced its weak transcription-promoting ability in females and became essential for producing the female phenotypes. This is the hypothesis that a useful functionality arose from a seemingly useless functionality. Both these hypotheses can explain the diversity in outputs of the sex differentiation system via the accumulation of coding mutations in existing genes. Thus, a heterotypic evolution may drive the evolution of outputs of the sex differentiation systems. Textbook examples of the heterotypic evolution include a mutation of human hemoglobin $\beta$ leading to sickle cells and coding mutations of Ultrabithorax that resulted in suppressed leg development in insects (reviewed in Arthur, 2010; Gilbert, 2013; Futuyma and Kirkpatrick, 2017). So far, heterotypy at the molecular level is considered as the change in the molecular function leading to entirely novel or no functions from existing functions of the molecule in phenotypes. On the other hand, the female isoform of $d s x$ shows no function in female phenotypes. 
481 Our hypotheses are models that a non-functional isoform gains functionality at the

482 phenotypic level. The heterotypic evolution may need to be divided into modification

483 from existing functions and innovation from non-functionality at phenotypic level.

$d s x$ in females by examining the expression of vitellogenin. In hemimetabolan insects.

the transcription-promoting function in females has not been found in vitellogenin

(Wexler et al., 2019; Zhuo et al., 2018), but might be detected in other female-specific

genes. Future comprehensive examination of the effects of $d s x$ by transcriptome and

comparisons at the mega-evolutionary level, i.e., higher taxa than families (Arthur,

2003), using broad insect taxa will test these hypotheses.

\section{Materials and Methods}

\section{Animals}

A firebrat, Thermobia domestica (Packard, 1873), was used as an emerging model apterygote. T. domestica is one of the species belonging to the Zygentoma

(Lepismatidae). The insects were kept at $37^{\circ} \mathrm{C}$ in total darkness condition and fed with

Stock colonies were reared in plastic cases of $30 \mathrm{~cm} \times 40 \mathrm{~cm}$ or $18 \mathrm{~cm} \times 25 \mathrm{~cm}$ in length. Eggs were collected from tissue paper in the case and incubated at $37^{\circ} \mathrm{C}$. For nymphal RNAi analysis, colonies of hatched nymphs were reared up to the fourth instar in a six-well plate and then transferred into 24-well plates to be kept individually. For adult RNAi analysis, adult insects were collected from the stock 
December, 2020. For adult RNAi, adult firebrats were manipulated from June to July,

506

507

508

509

510

511

512

513

514

515

516

517

518

519

520

521

522

523

524

525

526

527

528

529 2020.

\section{Estimation of molt timing}

Estimating the molt timing of insects is essential for the analysis of developmental processes and the functions of developmental regulatory genes. The timing of Hemi- or holometabolan insects can be estimated using morphological changes such as a wing growth. However, timing is hard to estimate in apterygote insects since they have little change in their morphology during postembryonic development. T. domestica forms scales in the fourth instar, and changes the number and length of its styli during the fourth to ninth instar under our breeding conditions. These features can be used to estimate molt timing, but it is difficult to apply these criteria to experiments using adults or a large number of nymphs. To resolve this problem, we used leg regeneration after autotomy and time-lapse imaging to estimate the molt timing of $T$. domestica. Autotomy occurs at the joint between the trochanter and femur in T. domestica. An autotomized leg regenerates after one molt (Buck and Edwards, 1990). For nymphal RNAi analysis, we amputated a right hindleg at the autotomic rift, using tweezers, and observed whether the leg had regenerated. This test enabled us to rapidly estimate the molt timing. For adult RNAi, time-lapse imaging was used to determine the precise time of molt. We build a time-lapse imaging system with a network camera system (SANYO, Tokyo, Japan) set in an incubator at $37^{\circ} \mathrm{C}$ (Figure 4-figure supplement 1A). Photos of insects in the 24-well plate were taken every five minutes. We created a time-lapse movie from the photos every 12 hours using ImageJ 1.52a (https://imagej.nih.gov/ij/) and observed whether the insects molted (Figure 4-figure supplement 1B, Video 1).

\section{De novo genome assembly}


A whole genome of $T$. domestica was sequenced to analyze the exon-intron structure of $d s x$. We selected an adult female of $T$. domestica from our stock colony and removed its alimentary canal. Genomic DNA was extracted from the sample using DNeasy Blood and Tissue Kit (QIAGEN K.K., Tokyo, Japan). A paired-end library was constructed from $1 \mu \mathrm{g}$ of the DNA using TruSeq DNA PCR-Free LT Sample Prep kits (Illumina K.K., Tokyo, Japan) following the manufacturer's instructions. The library was run on a sequencer (HiSeq 2500; Illumina K.K., Tokyo, Japan). We obtained $417 \mathrm{~Gb}$ of raw reads and assembled them using Platanus v1.2.4 assembler (Kajitani et al., 2014) after removal of the adapter sequences.

\section{Transcriptome analysis}

To search for doublesex (dsx) and vitellogenin (vtg) homologs, we performed RNA-seq analysis. Adults of $15 \stackrel{+}{\circ}$ and $15 \hat{\partial} \widehat{\partial}$ of T. domestica were sampled 1440 minutes after a molt in December, 2019. The fat bodies of the individuals were removed using tweezers in a phosphated buffered saline (PBS; $\mathrm{pH}=7.2$ ). Three adults were used per sample. Total RNA was extracted from 10 samples $(5 q q, 5 \overbrace{}^{\Uparrow})$ using RNeasy Micro kits (QIAGEN K.K., Tokyo, Japan) following the manufacturer's instructions. The concentration of purified RNA was measured using a Qubit 4 fluorometer (QIAGEN K.K., Tokyo, Japan) with Qubit RNA BR Assay kits (QIAGEN K.K., Tokyo, Japan). Paired-end libraries were constructed from 100 ng of the total RNAs using TruSeq RNA Library Prep kits v2 (Illumina K.K., Tokyo, Japan) following the manufacturer's instructions. The libraries were run on a sequence (Hiseq, Illumina, Tokyo, Japan). The library preparation and sequencing were performed by Genewiz Strand-Specific RNA-seq service. We mapped the reads obtained to the assembled genome using the HISAT2 program (Kim et al., 2019) with a default option and counted the mapped reads using the STRINGTie program 
555 (Pertea, 2015) with default parameter settings. Differential expression gene analysis

556 was performed based on the count matrix using the "edgeR" package (Robinson et al.,

557 2010) in R-v4.0.3 ( $R$ Core Team, 2020). Information about the samples can be

558 obtained from the National Center for Biotechnology Information (NCBI) BioSample

559 database (Accession number: SAMN18175012-SAMN18175021).

560 Molecular phylogenetic analysis

Dsx is a member of the Doublesex and Mab-3 Related transcriptional factors

(DMRT) family, and has a DNA binding domain, Doublesex and Mab-3 (DM)

572 figure supplement 1). Molecular phylogenetic analysis of the aligned sequences was

573 performed using a maximum likelihood method after selecting a substitution model calculated after 1000 replications.

576 Full-length cDNA and exon-intron structures 
We extracted total RNA from eggs, whole bodies, fat body, and gonads of nymphs and adult females and males of T. domestica using TRI Reagent (Molecular Research Center Inc., Ohio, USA) following the manufacturer's instructions. The total RNAs were treated with RNase-Free DNase I (New England BioLabs Japan Inc., Tokyo, Japan) to exclude remaining genomic DNA and purified by phenol/chloroform extraction and ethanol precipitation. For 5' -RACE analysis, mRNAs were purified from $75 \mu \mathrm{g}$ of the total RNAs using Dynabeads mRNA Purification kit (Thermo Fisher Scientific K.K., Tokyo, Japan) following the manufacturer's instruction. We then ligated an RNA oligo at the 5'-end of the mRNA using GeneRacer Advanced RACE kits (Thermo Fisher Scientific K.K., Tokyo, Japan). For 3'-RACE analysis, we ligated an RNA oligo of the SMART RACE cDNA Amplification Kit (Takara Bio Inc., Shiga, Japan) at $3^{\prime}$-end of the total RNA during reverse transcription. First stranded (fs-) cDNA was generated from the RNAs using SuperScript III Reverse Transcriptase (Thermo Fisher Scientific K.K., Tokyo, Japan). We used primers specific to the RNA oligos and performed RACE analysis by nested RT-PCR using Q5 High-Fidelity DNA polymerase (New England BioLabs Japan Inc., Tokyo, Japan). The primers specific to $d s x$ and $d s x$-like were made from sequences of the relevant genomic regions and are listed in Table 6. The amplicons were separated using the agarose gel-electrophoresis and cloned using TOPO TA Cloning Kit for Sequencing (Thermo Fisher Scientific K.K., Tokyo, Japan) following the manufacture's protocol. We used a DH5 $\alpha$ Escherichia coli strain (TOYOBO CO., LTD., Osaka, Japan) as the host cell. Plasmids were extracted using the alkaline lysis and purified by phenol-chloroform and ethanol precipitation. The nucleotide sequences of the cloned amplicons were determined from the purified plasmids by the Sanger Sequencing service of FASMAC Co. Ltd. (Kanagawa, Japan). We then 
searched the genomic region of the full-length cDNA sequences of $d s x$ and $d s x$-like via local blastn analysis.

\section{Reverse transcription-quantitative PCR (RT-qPCR)}

To quantitative mRNA expression levels, we performed RT-qPCR analysis.

For investigating the sex-specific expression profile of $d s x$ and $d s x$-like, we used the

fat body of adults of $T$. domestica since the sexes can be distinguishable by the

external morphology at this stage. Fat bodies also exhibit sex-specific physiological

functions in adults. Thirteenth instar individuals and adults after molting were

sampled for nymphal and adult RNAi analyses, respectively. The sample sizes are

reported in the Table 2. We dissected the individuals in PBS and collected their fat

body in $2 \mathrm{ml}$ tubes containing TRI Reagent (Molecular Research Center Inc., Ohio,

USA). The fat bodies then were disrupted using a TissueLyser LT small beads mill

(QIAGEN K.K., Tokyo, Japan). These disrupted samples were preserved at $-80^{\circ} \mathrm{C}$

until used. Total RNA was extracted from the samples according to the manufacture's protocol for the TRI Reagent. Extracted RNA was treated with 2\% RNase-free DNase I (New England BioLabs Japan Inc., Tokyo, Japan) at $37^{\circ} \mathrm{C}$ for 40 minutes and purified by phenol/chloroform extraction and ethanol precipitation. We measured the concentration of the total RNA using a spectrophotometer (DS-11+, Denovix Inc., Wilmington, USA). fs-cDNA was synthesized from $350 \mathrm{ng}$ of the total RNA using SuperScript III Reverse Transcriptase (Thermo Fisher Scientific K.K., Tokyo, Japan). We diluted the fs-cDNA to 1:2 with MilliQ water and preserved it at $-30^{\circ} \mathrm{C}$ until it was used in RT-qPCR assay. The RT-qPCR assays were performed using a LightCycler 96 instrument (Roche, Basel, Switzerland) according to the manufacture's protocol with the THUNDERBIRD SYBR qPCR Mix (TOYOBO Co. 
templates. The preparation of the RT-qPCR solution proceeded on ice. The protocol of the RT-qPCR was as follows: preincubation at $95^{\circ} \mathrm{C}$ for 600 seconds and 45 cycles of three-step reactions, such as denaturation at $95^{\circ} \mathrm{C}$ for 15 seconds, annealing at $60^{\circ} \mathrm{C}$ for 15 seconds and extension at $72^{\circ} \mathrm{C}$ for 45 seconds. We used ribosomal protein 49 (rp49) as a reference gene, as described by Ohde et al. (2011). We designed primer sets of the target genes by the Primer3Web version 4.1.0 (Untergasser et al., 2012) following the manufacture's recommended condition of the THUNDERBIRD SYBR qPCR Mix. We confirmed the primers' specificity using melting curves ranging from $65^{\circ} \mathrm{C}$ to $95^{\circ} \mathrm{C}$. We selected primer sets exhibiting a single peak. The primers are listed in Table 6. Each RT-qPCR was technically replicated three times. Some samples were excluded before analyzing the data when the $\mathrm{Ct}$ value of any genes was not detected (ND) in one or more replicates or when the $\mathrm{Ct}$ value of the reference gene deviated from that of other samples. In these removed data, a technical error was suspected. We calculated the expression level of target genes by the $2^{-\Delta \Delta \mathrm{Ct}}$ method (Livak and Schmittgen, 2001) and performed the Brunner-Munzel (BM) test for $\Delta \mathrm{Ct}$ value. The BM test was carried out using R-v4.0.3. with the brunnermuzel.test function of the "brunnermuzel” package (https://cran.rproject.org/web/packages/brunnermunzel/index.html). Holm's method was used for multiple comparison analyses between the control and treatments. The data are listed in Table 2. Also, its source data can be found in Table2-Source Data 1. In the $d s x$ expression of the RNAi male, we performed the Smirnov-Grubbs (SG) test for $\Delta \mathrm{Ct}$ value using the grubbs.test function of the "outliers" package in R (https://cran.rproject.org/web/packages/outliers/index.html) (Table 3). An outlier was detected in the $d s x$ RNAi male. We repeatedly performed the SG test using the data excluding the 
outlier. No further outliers were detected. Lastly, we re-analyzed the data, excluding the outlier, using the BM test (Table 2).

\section{RNAi analysis}

$$
\text { Nymphal RNAi can be used to analyze the roles of genes during }
$$

postembryonic development. The sexual differentiation of insects is generally assumed to be a cell-autonomous mechanism that is independent of systemic hormonal- control (Verhulst and van de Zande, 2015) as discussed in De Loof and Huybrechts (1998) and Bear and Monteiro (2013) and progresses during postembryonic development. Therefore, nymphal RNAi is the most effective tool to investigate the roles of genes on sexual trait formation. To reduce the possibility of off-target effects, the dsRNA was designed to avoid the region of the DM domain. We also confirmed that the dsRA had no contiguous matches of more than 20 bases with other regions of the genome. To produce templates for the dsRNA, we cloned the regions of $d s x$ and $d s x$-like from the fs-cDNA using the same method as the RACE analysis. We amplified the template DNAs from purified plasmids with PCR using Q5 High-Fidelity DNA Polymerase and purified the amplified DNA with the phenol/chloroform extraction and the ethanol precipitation. dsRNA was synthesized from the purified DNA using Ampliscribe T7-Flash Transcription kits (Epicentre Technologies, Co., Wisconsin, USA). We designed the PCR primers using the Primer3Web version 4.1.0 (Untergasser et al., 2012). The PCR primers are listed in Table 6. In nymphal RNAi analysis, we injected the dsRNAs repeatedly into the abdomen of the nymphs of $T$. domestica with each molt from the fourth or fifth instar to thirteenth instar to sustain the RNAi effect during postembryonic development. The initial stage was the same within a single experiment. This repeated nymphal RNAi was effective in some insects such as Blattella germanica (Wexler et al., 2014). We 
sampled the individuals one, three, and five days after molting, using phenotypic observations, analysis of $d s x$ knockdown effects, and the oocyte size and number. To determine the sex of individuals, we initially observed the gonads: testis and ovary. In our nymphal RNAi analysis, the gonad s completely formed and there was no difference between the control and $d s x$ RNAi individuals in external morphology (Figures 1-figure supplement 3, Figure2-figure supplement 1A). Therefore, at least in this assay, the gonad morphology was effective for the identification of the sex of $d s x$ RNAi individuals. Individuals with testis were males and those with ovaries were females. For the analysis of $v t g$ genes, we used the adult RNAi assay. T. domestica molts throughout its life, even after sexual maturation, and produces $v t g$ during each adult instar (Rouset and Bitsch, 1993). In the adult RNAi analysis, we injected dsRNA repeatedly into the adults every three days. The dsRNA was initially injected into adults 12 hours after molting. We sampled the adults at $720 \pm 20$ minutes after subsequently molts, to analyze the $v t g$ mRNA levels.

\section{Phenotype observation}

We dissected thirteenth instar individuals in PBS using tweezers and removed the thoraxes, reproductive systems, and external genital organs. We took images using the digital microscope system (VHX-5000, KEYENCE, Tokyo, Japan). The thoraxes and external genital organs were fixed with FAA fixative (formaldehyde: ethanol: acetic acid $=15: 5: 1)$ at $25^{\circ} \mathrm{C}$ overnight and then preserved in 90\% ethanol. We used the length of the prothorax as an indicator of body size. To measure the prothoracic width, the prothoracic notum was removed from the fixed thorax after treatment with $10 \% \mathrm{NaOH}$ solution at $60^{\circ} \mathrm{C}$ for 30 minutes to dissolve the soft tissues. The notum was mounted in Lemosol on a microscope slide. The prepared specimens were imaged using a KEYENCE VHX-5000. With the microscope at 50×, the length of the notum 
was measured. The ovipositor length and oocyte size were also measured using the microscope at $20 \times$ and $50 \times$. The oocyte size was taken to be the major length of the late vitellogenic oocyte at the posterior most part of the ovariole. To count the sperm number, sperm was collected from seminal vesicles and diluted with $5 \mathrm{ml}$ MilliQ water. $50 \mu \mathrm{l}$ of the diluted sperm was spotted on a microscope slide and dried overnight. We technically replicated the measurement three times for ovipositor length and six times in sperm number and calculated these means. Measurement was performed by blinding the treatment. We counted the number of oocytes in ovarioles using an optical microscope at 50× (Olympus, Tokyo, Japan). A generalized linear model (GLM) was used to analyze differences in ovipositor length and oocyte size (length data) and sperm and oocyte number (count data) among RNAi treatments. The body size, target genes, and interactions between the target genes were used as explanatory variables. The length was assumed to follow a Gaussian distribution, and the count data to have a negative binomial distribution. We used R-v4.0.3 in these analyses and the $g l m$ and the $g \operatorname{lm} . n b$ (MASS package) functions for the length and count data, respectively. To analyze the contribution of the explanatory variables, a likelihood ratio test for the result of GLM was performed using the Anova function of the car package. The statistical results are listed in Tables 4 (female) and 5 (male). Also, the source data are reported in Table 4-source data 1 and Table 5-source data 1.

\section{Scanning Electron Microscopy (SEM)}

The NanoSuit method (Takaku et al., 2013) was used for the SEM analysis. Male penises and female ovipositors preserved in $90 \%$ ethanol were washed with distilled water and immersed in $1 \%$ Tween 20 at $25^{\circ} \mathrm{C}$ for 10 minutes. The samples were mounted on stubs and imaged using a low-vacuum SEM (DX-500; KEYENCE, Tokyo, Japan). 


\section{Histology}

730 The gonads of RNAi individuals were fixed with Bouin's fixative (saturated picric

731 acid: formaldehyde: glacial acetic acid $=15: 5: 1)$ at $25^{\circ} \mathrm{C}$ overnight and washed with 90\% ethanol plus Lithium Carbonate $\left(\mathrm{Li}_{2} \mathrm{CO}_{3}\right)$. The ovipositors of RNAi individuals were fixed with FAA fixative at $25^{\circ} \mathrm{C}$ overnight and then were transferred into $90 \%$ ethanol. The samples were dehydrated and cleared with an ethanol-butanol series. The cleared samples were immersed and embedded in paraffin at $60^{\circ} \mathrm{C}$. The paraffin blocks were polymerized at $4{ }^{\circ} \mathrm{C}$ and cut into $5 \mu \mathrm{m}$ thick sections using a microtome (RM2155: Leica, Wetzlar, Germany). The sections were mounted on microscope slides coated with egg white-glycerin and stained using Delafield's Hematoxylin and Eosin staining. The stained slides were enclosed with Canada balsam. We observed the slides on an optical microscope (Olympus, Tokyo, Japan) and took photos using a digital single-lens reflex camera (Nikon, Tokyo, Japan).

\section{Comparison of exon-intron structure and amino acid sequences}

We obtained exon-intron structures of $d s x$ in seven insect species from NCBI. The

female- and male-specific regions were visualized as red and blue colors, respectively.

The exon-intron structures were mapped on a phylogenetic hypothesis based on Misof et al. (2014). We obtained amino acid sequences of Dsx isoforms of 10 species from the NCBI database. Wexler et al. (2014) showed that $d s x$ of Pediculus humanus (Psocodea) has isoforms without sex-specificity. In this study, based on the blast search and exon structure, we determined that PhDsx 1 in Wexler et al. (2019) corresponded to the $d s x$ female-type and PhDsx 2 to $d s x$ male-type. The sequences were aligned using MAFFT version 7 with a -linsi option.

\section{Data availability}


753 The draft genome data was deposited in the DNA Data Bank of Japan (Accession

754 number: DRA005797; Bioproject: PRJDB5781). The raw read data of the

755 transcriptome was in the NCBI Sequence Read Archive (Accession numbers:

756 SRR13870115-SRR13870124; Bioproject: PRJNA707122). The sequences of $d s x$

757 male-type, $d s x$ female-type, and $d s x$-like are also in GenBank (Accession numbers:

758 MW711323, MW711324, and MW711325, respectively).

759

760 Acknowledgments

761 We would like to thank Dr. Takahiro Ohde (National Institute for Basic Biology;

762 Kyoto University) for his help to extract genomic DNA of T. domestica and for a

763 great advice to the discussion. We are also grateful to Dr. Toshiya Ando, Dr. Taro

764 Nakamura, Dr. Shinichi Morita, Dr. Hiroki Sakai, and Dr. Tatsuro Konagaya

765 (National Institute for Basic Biology) for technical advice and discussion on this

766 manuscript. We also express our gratitude to Dr. Morita for providing a photo of

767 Daphnia magna. Computations were performed on the NIG supercomputer at ROIS,

768 National Institute of Genetics and the Data Integration and Analysis Facility, National

769 Institute for Basic Biology. We thank the Model Plant Research Facility, NIBB

770 Bioresource Center for providing the network camera system. This work was

771 supported by the JSPS KAKENHI Grant numbers JP25660265, JP16H02596, and

772 JP16H06279 (PAGS) for TN and the Sasakawa Scientific Research Grant from The

773 Japan Science Society for YC.

774

775 Author Contributions: 
YC and TN conceived this study. YC performed the cloning of $d s x$ and $d s x$-like, the RNAi, the RNA-seq, and the molecular phylogenetic analysis. AT sequenced the genome. MO and TI performed the de novo genome assembly. YC and T. wrote this manuscript; all authors commented on the manuscript.

\section{Competing Interest Statement}

The authors declare that have no competing interests.

\section{References}

Abouheif E. 1999. A method for testing the assumption of phylogenetic independence in comparative data. Evolutionary Ecology Research 1: 895-909.

An W, Wensink PC. 1995. Integrating sex-and tissue-specific regulation within a single Drosophila enhancer. Genes \& Development 9: 256-266.

Arthur W. 2003. Micro-, Macro-, and Megaevolution In: Hall BK, Olson WM (Eds). Keywords and Concepts in Evolutionary Developmental Biology. Cambridge: Harvard University Press. p. 249-260.

Arthur W. 2010. Evolution: A Developmental Approach. New York: John Wiley \& Sons.

Bachtrog D, Mank JE, Peichel CL, Kirkpatrick M, Otto SP, Ashman TL, Hahn MW, Kitano J, Mayrose I, Ming R, Perrin N, Ross L, Valenzuela N, Vamosi JC, Tree of Sex Consortium. 2014. Sex determination: why so many ways of doing it? PLoS Biol 12: e1001899. 
Baral S, Arumugam G, Deshmukh R, Kunte K. 2019. Genetic architecture and sexspecific selection govern modular, male-biased evolution of doublesex. Science Advances 5: eaau3753.

Bear A, Monteiro A. 2013. Both cell-autonomous mechanisms and hormones contribute to sexual development in vertebrates and insects. Bioessays 35: 725732.

Beukeboom LW, Perrin N. 2014. The evolution of sex determination. Oxford: Oxford University Press.

Beutel RG, Yavorskaya MI, Mashimo Y, Fukui M, Meusemann K. 2017. The phylogeny of Hexapoda (Arthropoda) and the evolution of megadiversity. Proceedings of the Arthropodan Embryological Society of Japan 51: 1-15.

Bopp D, Saccone G, Beye M. 2014. Sex determination in insects: variations on a common theme. Sexual Devevelopment 8: 20-28.

Boudinot BE. 2018. A general theory of genital homologies for the Hexapoda (Pancrustacea) derived from skeletomuscular correspondences, with emphasis on the Endopterygota. Arthropod Structure \& Development 47: 563-613.

Buck C, Edwards JS. 1990. The effect of appendage and scale loss on instar duration in adult firebrats, Thermobia domestica (Thysanura). Journal of Experimental Biology 151: 341-347.

Burtis KC, Baker BS. 1989. Drosophila doublesex gene controls somatic sexual differentiation by producing alternatively spliced mRNAs encoding related sexspecific polypeptides. Cell 56: 997-1010.

Byrne BM, Gruber MABG, Ab G. 1989. The evolution of egg yolk proteins. Progress in Biophysics \&Molecular Biology 53: 33-69. 
822 Caroll SB. 2005. Evolution at Two Levels: On Genes and Form. PLoS Biol. 3,:e245.

823 Chandler JC, Fitzgibbon QP, Smith G, Elizur A, Ventura T. 2017. Y-linked iDmrt1

824 paralogue (iDMY) in the Eastern spiny lobster, Sagmariasus verreauxi: The first

825 invertebrate sex-linked Dmrt. Developmental Biology 430: 337-345.

826 Darwin C. 1871. The Descent of Man, and Selection in Relation to Sex vol. 1 London:

827 John Murray.

828 De Loof A, Huybrechts R. 1998. "Insects do not have sex hormones": a myth?

829 General and Comparative Endocrinology 111: 245-260.

830 Emeljanov AF. 2014. The evolutionary role and fate of the primary ovipositor in

831 insects. Entomological Review 94: 367-396.

832 Erdman SE, Chen HJ, Burtis KC. 1996. Functional and genetic characterization of the 833 oligomerization and DNA binding properties of the Drosophila doublesex proteins.

$834 \quad$ Genetics 144: 1639-1652.

835 Fryxell DC, Weiler DE, Kinnison MT, Palkovacs EP. 2019. Eco-evolutionary

836 dynamics of sexual dimorphism. Trends in Ecology and Evolution 34: 591-594.

837 Futuyma D, Kirkpatrick M. 2017. Evolution 4th edition Sunderland: Sinauer

$838 \quad$ Associates.

839 Ganfornina MD, Sánchez D. 1999. Generation of evolutionary novelty by functional

$840 \quad$ shift. Bioessays 21: 432-439.

841 Geddes P, Thomson JA. 1889. The evolution of sex. London: Walter Scott.

842 Gempe T, Hasselmann M, Schiøtt M, Hause G, Otte M, Beye M. 2009. Sex

843 determination in honeybees: two separate mechanisms induce and maintain the

$844 \quad$ female pathway. PLoS Biol. 7: e1000222. 
845 Ghosh N, Bakshi A, Khandelwal R, Rajan SG, Joshi R. 2019. The Hox gene

846 Abdominal-B uses Doublesex ${ }^{\mathrm{F}}$ as a cofactor to promote neuroblast apoptosis in the

847 Drosophila central nervous system. Development 146: dev175158.

848 Gilbert SF. 2013. Developmental Biology 10th edition. Sunderland: Sinauer

$849 \quad$ Associates.

850 Gotoh H, Zinna RA, Warren I, DeNieu M, Niimi T, Dworkin I, Emlen DJ, Miura T,

851 Lavine LC. 2016. Identification and functional analyses of sex determination genes

852 in the sexually dimorphic stag beetle Cyclommatus metallifer. BMC Genomics 17:

853250.

854 Gubbay J, Collignon J, Koopman P, Capel B, Economou A, Münsterberg A, Vivian

855 N, Goodfellow P, Lovell-Badge R. 1990. A gene mapping to the sex-determining

856 region of the mouse $\mathrm{Y}$ chromosome is a member of a novel family of

857 embryonically expressed genes. Nature 346: 245-250.

858 Hasselmann M, Gempe T, Schiøtt M, Nunes-Silva CG, Otte M, Beye M. 2008.

859 Evidence for the evolutionary nascence of a novel sex determination pathway in

$860 \quad$ honeybees. Nature 454: 519-522.

861 Hattori, Y. Murai, M. Oura, S. Masuda, S. K. Majhi, T. Sakamoto, J. I. Hattori RS,

862 Murai Y, Oura M, Masuda S, Majhi SK, Sakamoto T, Fernandino JI, Somoza GM,

863 Yokota M, Strüssmann CA. 2012. A Y-linked anti-Müllerian hormone duplication

864 takes over a critical role in sex determination. PNAS 109: 2955-2959.

865 Hayward A, Takahashi T, Bendena WG, Tobe SS, Hui JH. 2010. Comparative

866 genomic and phylogenetic analysis of vitellogenin and other large lipid transfer

867 proteins in metazoans. FEBS Letters 584: 1273-1278. 
868 Herpin A, Schartl M. 2015. Plasticity of gene-regulatory networks controlling sex

869 determination: of masters, slaves, usual suspects, newcomers, and usurpators.

$870 \quad$ EMBO Reports 16: 1260-1274.

871 Hildreth PE. 1965. Doublesex, a recessive gene that transforms both males and

872 females of Drosophila into intersexes. Genetics 51: 659-678.

873 Hopkins BR, Kopp A. 2021. Evolution of sexual development and sexual dimorphism

874 in insects. Current Opinion in Genetics \& Development 69: 129-139.

875 Ito Y, Harigai A, Nakata M, Hosoya T, Araya K, Oba Y, Ito A, Ohde T, Yaginuma T,

876 Niimi T. 2013. The role of doublesex in the evolution of exaggerated horns in the

877 Japanese rhinoceros beetle. EMBO Reports 14: 561-567.

878 Luo SD, Baker BS. 2015. Constraints on the evolution of a doublesex target gene

879 arising from doublesex's pleiotropic deployment. PNAS 112: 852-861.

880 Kamiya T, Kai W, Tasumi S, Oka A, Matsunaga T, Mizuno N, Fujita M, Suetake H,

881 Suzuki S, Hosoya S, Tohari S, Brenner S, Miyadai T, Venkatesh B, Suzuki Y,

882 Kikuchi K. 2012. A trans-species missense SNP in Amhr2 is associated with sex

883 determination in the tiger pufferfish, Takifugu rubripes (fugu). PLoS Genetics 8:

$884 \quad$ e1002798.

885 Kajitani R, Toshimoto K, Noguchi H, Toyoda A, Ogura Y, Okuno M, Yabana M,

886 Harada M, Nagayasu E, Maruyama H, Kohara Y, Fujiyama A, Hayashi T, Itoh T.

887 2014. Efficient de novo assembly of highly heterozygous genomes from whole-

888 genome shotgun short reads. Genome Reserach 24:1384-95.

889 Kato Y, Kobayashi K, Watanabe H, Iguchi T. 2011. Environmental sex determination

890 in the branchiopod crustacean Daphnia magna: deep conservation of a Doublesex

891 gene in the sex-determining pathway. PLOS Genet. 7: e1001345. 
Katoh K, Standley DM. 2013. MAFFT multiple sequence alignment software version 7: improvements in performance and usability. Molecular Biology and Evolution 30: $772-780$.

Keren H, Lev-Maor G, Ast G. 2010. Alternative splicing and evolution: diversification, exon definition and function. Nature Review Genetics 11: 345-355.

Kijimoto T, Moczek AP, Andrews J. 2012. Diversification of doublesex function underlies morph-, sex-, and species-specific development of beetle horns. PNAS 109: 20526-20531.

Kim D, Paggi JM, Park C, Bennett C, Salzberg SL. 2019. Graph-based genome alignment and genotyping with HISAT2 and HISAT-genotype. Nature Biotechnology 37: 907-915.

Koopman P, Gubbay J, Vivian N, Goodfellow P, Lovell-Badge R. 1991. Male development of chromosomally female mice transgenic for Sry. Nature 351: 117121.

Kopp A. 2012. Dmrt genes in the development and evolution of sexual dimorphism. Trends in Genetics 28: 175-184.

Kristensen NP. 1975. The phylogeny of hexapod "orders". A critical review of recent accounts. Journal of Zoological Systematics and Evolutionary Research 13: 1-44.

Kumar S, Stecher G, Li M, Knyaz C, Tamura K. 2018. MEGA X: molecular evolutionary genetics analysis across computing platforms. Molecular Biology and Evolution 35: 1547-1549.

Ledón-Rettig C, Zattara E, Moczek A. 2017. Asymmetric interactions between doublesex and tissue- and sex-specific target genes mediate sexual dimorphism in beetles. Nature Communications 8: 14593. 
Li S, Li F, Yu K, Xiang J. 2018. Identification and characterization of a doublesex gene which regulates the expression of insulin-like androgenic gland hormone in Fenneropenaeus chinensis. Gene 649: 1-7.

Livak KJ, Schmittgen TD. 2001. Analysis of relative gene expression data using realtime quantitative PCR and the $2^{-\Delta \Delta \mathrm{CT}}$ method. Methods 25: 402-408.

Mann RM, Caroll SB. 2002. Molecular mechanisms of selector gene function and evolution. Current Opinion in Genetics \& Development 5: 592-600.

Matsuda M, Nagahama Y, Shinomiya A, Sato T, Matsuda C, Kobayashi T, Morrey CE, Shibata N, Asakawa S, Shimizu N, Hori H, Hamaguchi S, Sakaizumi M. 2002. DMY is a Y-specific DM-domain gene required for male development in the medaka fish. Nature 417: 559-563.

Matsuda R.1976. Morphology and Evolution of the Insect Abdomen: With Special Reference to Developmental Patterns and their Bearings upon Systematics. Oxford: Pergamon Press.

Mawaribuchi S, Ito Y, Ito M. 2019. Independent evolution for sex determination and differentiation in the DMRT family in animals. Biology Open 8: bio041962.

McQueen E, Rebeiz M. 2020. On the specificity of gene regulatory networks: How does network co-option affect subsequent evolution? Current Topics in Developmental Biology 139: 375-405.

Mine S, Sumitani M, Aoki F, Hatakeyama M, Suzuki MG. 2017. Identification and functional characterization of the sex-determining gene doublesex in the sawfly, Athalia rosae (Hymenoptera: Tenthredinidae). Applied Entomology and Zoology 52: 497-509.

Misof B, Liu S, Meusemann K, Peters RS, Donath A, Mayer C, Frandsen PB, Ware J, Flouri T, Beutel RG, Niehuis O, Petersen M, Izquierdo-Carrasco F, Wappler T, 

of insect evolution. Science 346: 763-767. Science 370, 121-124.

Miyazaki S, Fujiwara K, Kai K, Masuoka Y, Gotoh H, Niimi T, Hayashi Y, Shigenobu S, Maekawa K. 2021. Evolutionary transition of doublesex regulation in termites and cockroaches: from sex-specific splicing to male-specific transcription. bioRxiv. Precise staging of beetle horn formation in Trypoxylus dichotomus reveals the pleiotropic roles of doublesex depending on the spatiotemporal developmental contexts. PLOS Genetics 15: e1008063. 
Myosho T, Takehana Y, Hamaguchi S, Sakaizumi M. 2015. Turnover of sex

$$
\text { chromosomes in celebensis group medaka fishes. G3: Genes, Genomes, Genetics }
$$
5: $2685-2691$.

Myosho T, Otake H, Masuyama H, Matsuda M, Kuroki Y, Fujiyama A, Naruse K, Hamaguchi S, Sakaizumi M. 2012. Tracing the emergence of a novel sexdetermining gene in medaka, Oryzias luzonensis. Genetics 191: 163-170.

Nanda I, Kondo M, Hornung U, Asakawa S, Winkler C, Shimizu A, Shan Z, Haaf T, Shimizu N, Shima A, Schmid M, Schartl M. 2002. A duplicated copy of DMRT1 in the sex-determining region of the Y chromosome of the medaka, Oryzias latipes. PNAS 99: 11778-11783.

Ohbayashi F, Suzuki MG, Mita K, Okano K, Shimada T. 2001. A homologue of the Drosophila doublesex gene is transcribed into sex-specific mRNA isoforms in the silkworm, Bombyx mori. Comparative Biochemistry and Physiology - Part B: Biochemistry \& Molecular Biology 128: 145-158.

Ohde T, Yaginuma T, Niimi T. 2011. Nymphal RNAi analysis reveals novel function of scalloped in antenna, cercus and caudal filament formation in the firebrat, Thermobia domestica. Journal of Insect Biotechnology and Sericology 80: 101108.

Panara V, Budd GE, Janssen R. 2019. Phylogenetic analysis and embryonic expression of panarthropod Dmrt genes. Frontiers in Zoology 16: 1-18.

Pertea M, Pertea GM, Antonescu CM, Chang TC, Mendell JT, Salzberg SL. 2015. StringTie enables improved reconstruction of a transcriptome from RNA-seq reads. Nature Biotechnology 33: 290-295.

Pomerantz AF, Hoy MA, Kawahara AY. 2015. Molecular characterization and evolutionary insights into potential sex-determination genes in the western orchard 
predatory mite Metaseiulus occidentalis (Chelicerata: Arachnida: Acari:

Phytoseiidae). Journal of Biomolecular Structure and Dynamics 33: 1239-1253.

Raymond CS, Murphy MW, O'Sullivan MG, Bardwell VJ, Zarkower D. 2000. Dmrt1, a gene related to worm and fly sexual regulators, is required for mammalian testis differentiation. Genes \& Development 14: 2587-2595.

Raymond CS, Shamu CE, Shen MM, Seifert KJ, Hirsch B, Hodgkin J, Zarkower D. 1998. Evidence for evolutionary conservation of sex-determining genes. Nature, 391, 691-695.

R Core Team. 2020. R: A language and environment for statistical computing. $\mathrm{R}$ Foundation for Statistical Computing.

Robinson MD, McCarthy DJ, Smyth GK. 2010. edgeR: a Bioconductor package for differential expression analysis of digital gene expression data. Bioinformatics 26: Herrero E. 2019. Cooperation of axial and sex specific information controls Drosophila female genitalia growth by regulating the Decapentaplegic pathway. Developmental Biology 454: 145-155.

Rousset A., Bitsch C. 1993. Comparison between endogenous and exogenous yolk proteins along an ovarian cycle in the firebat Thermobia domestica (Insecta, Thysanura). Comparative Biochemistry and Physiology Part B: Biochemistry and Molecular Biology104: 33-44.

Sato Y, Shinka T, Sakamoto K, Ewis AA, Nakahori Y. 2010. The male-determining gene $S R Y$ is a hybrid of $D G C R 8$ and $S O X 3$, and is regulated by the transcription factor CP2. Molecular and Cellular Biochemistry 337: 267-275. 
Sharma A, Heinze SD, Wu Y, Kohlbrenner T, Morilla I, Brunner C, Wimmer EA, van

$$
\text { de Zande L, Robinson MD, Beukeboom LW, Bopp D. 2017. Male sex in }
$$

$$
\text { houseflies is determined by } M d m d \text {, a paralog of the generic splice factor gene }
$$
CWC22. Science 356: 642-645.

Shukla JN, Palli SR. 2012. Doublesex target genes in the red flour beetle, Tribolium castaneum. Scientific Reports 2: 948.

Sinclair AH, Berta P, Palmer MS, Hawkins JR, Griffiths BL, Smith MJ, Foster JW, Frischauf AM, Lovell-Badge R, Goodfellow PN. 1990. A gene from the human sex-determining region encodes a protein with homology to a conserved DNAbinding motif. Nature 346: 240-244.

Smith CA, Roeszler KN, Ohnesorg T, Cummins DM, Farlie PG, Doran TJ, Sinclair AH. 2009. The avian Z-linked gene DMRT1 is required for male sex determination in the chicken. Nature 461: 267-271.

Suzuki MG, Funaguma S, Kanda T, Tamura T, Shimada T. 2003. Analysis of the biological functions of a doublesex homologue in Bombyx mori. Developmental Genes and Evolution 213: 345-354.

Suzuki MG, Imanishi S, Dohmae N, Nishimura T, Shimada T, Matsumoto S. 2008. Establishment of a novel in vivo sex-specific splicing assay system to identify a trans-acting factor that negatively regulates splicing of Bombyx mori dsx female exons. Molecular and Cellular Biology 28: 333-343.

Takaku Y, Suzuki H, Ohta I, Ishii D, Muranaka Y, Shimomura M, Hariyama T. 2013. A thin polymer membrane, nano-suit, enhancing survival across the continuum between air and high vacuum. PNAS 110:7631-7635. 
Takahashi M, Okude G, Futahashi R, Takahashi Y, Kawata M. 2021. The effect of the doublesex gene in body colour masculinization of the damselfly Ischnura senegalensis. Biology Lettters 17: 20200761.

Takahashi M, Takahashi Y, Kawata M. 2019. Candidate genes associated with color morphs of female-limited polymorphisms of the damselfly Ischnura senegalensis. Heredity 122: 81-92.

Takehana Y, Matsuda M, Myosho T, Suster ML, Kawakami K, Shin-I T, Kohara Y, Kuroki Y, Toyoda A, Fujiyama A, Hamaguchi S, Sakaizumi M, Naruse K. 2014. Co-option of Sox3 as the male-determining factor on the Y chromosome in the fish Oryzias dancena. Nature Communications 5: 4157.

Thongsaiklaing T, Passara H, Nipitwathanaphon M, Ngernsiri L. 2018. Identification and characterization of doublesex from the pumpkin fruit fly, Bactrocera tau (Diptera: Tephritidae). European Journal of Entomology 115: 602-613.

True JR, Carroll SB. 2002. Gene co-option in physiological and morphological evolution. Annual Review of Cell and Developmental Biology 18: 53-80.

Untergasser A, Cutcutache I, Koressaar T, Ye J, Faircloth BC, Remm M, Rozen SG. 2012. Primer3--new capabilities and interfaces. Nucleic Acids Research 40: e115.

Verhulst EC, van de Zande L. 2015. Double nexus-Doublesex is the connecting element in sex determination. Briefings in Functional Genomics 14: 396-406.

Verhulst EC, van de Zande L, Beukeboom LW. 2010. Insect sex determination: it all evolves around transformer. Current Opinion in Genetics \& Development 20: $376-383$.

Wexler J, Delaney EK, Belles X, Schal C, Wada-Katsumata A, Amicucci MJ, Kopp A. 2019. Hemimetabolous insects elucidate the origin of sexual development via alternative splicing. eLife 8: e47490. 
1062

1063

1064

1065

1066

1067

1068

1069

1070

1071

1072

1073

1074

1075

1076

1077

1078

1079

1080

1081

1082

1083

Wexler JR, Plachetzki DC, Kopp A. 2014. Pan-metazoan phylogeny of the DMRT gene family: a framework for functional studies. Developmental Genes and Evolution 224: 175-181.

Wilkins AS. 1995. Moving up the hierarchy: a hypothesis on the evolution of a genetic sex determination pathway. Bioessays 17: 71-77.

Xu J, Chen S, Zeng B, James AA, Tan A, Huang Y. 2017. Bombyx mori P-element Somatic Inhibitor (BmPSI) is a key auxiliary factor for silkworm male sex determination. PLoS Genetics 13: e1006576.

Xu J, Yu Y, Chen K, Huang Y. 2019. Intersex regulates female external genital and imaginal disc development in the silkworm. Insect Biochemistry and Molecular Biology 108: 1-8.

Xu J, Zhan S, Chen S, Zeng B, Li Z, James AA, Tan A, Huang Y. Sexually dimorphic traits in the silkworm, Bombyx mori, are regulated by doublesex. 2017. Insect Biochemistry and Molecular Biology 80: 42-51.

Yang Y, Zhang W, Bayrer JR, Weiss MA. 2008. Doublesex and the regulation of sexual dimorphism in Drosophila melanogaster: structure, function, and mutagenesis of a female-specific domain. Journal of Biological Chemistry 283: $7280-7292$.

Yoshimoto S, Okada E, Umemoto H, Tamura K, Uno Y, Nishida-Umehara C, Matsuda Y, Takamatsu N, Shiba T, Ito M. 2008. A W-linked DM-domain gene, $D M-W$, participates in primary ovary development in Xenopus laevis. PNAS 105: 2469-2474. 
1084 Zhang HH, Xie YC, Li HJ, Zhuo JC, Zhang CX. 2021. Pleiotropic roles of the

1085 orthologue of the Drosophila melanogaster Intersex gene in the brown

$1086 \quad$ planthopper. Genes 12: 379.

1087 Zhuo JC, Hu QL, Zhang HH, Zhang MQ, Jo SB, Zhang CX. 2018. Identification and

1088 functional analysis of the doublesex gene in the sexual development of a

1089 hemimetabolous insect, the brown planthopper. Insect Biochemistry and Molecular

1090 Biology 102: 31-42.

1091 
bioRxiv preprint doi: https://doi.ora/10.1101/2021.08.02.454784: this version posted Auqust 5.2021 . The copvriaht holder for this preprint (which was not certified by peer review) is the author/funder, who has granted bioRxiv a license to display the preprint in perpetuity. It is made available under aCC-BY 4.0 International license.

\section{Video}

1093 Video 1. Time-lapse imaging of molting of Thermobia domestica.

1094 
bioRxiv preprint doi: https://doi.org/10.1101/2021.08.02.454784; this version posted August 5, 2021. The copyright holder for this preprint (which was not certified by peer review) is the author/funder, who has granted bioRxiv a license to display the preprint in perpetuity. It is made available under aCC-BY 4.0 International license.

\section{Tables}

\section{Table 1. Taxa and proteins used for molecular phylogenetic analysis of DMRT}

\section{7 family.}

\begin{tabular}{|c|c|c|c|c|c|c|c|}
\hline $\begin{array}{c}\text { OTU } \\
\text { name }\end{array}$ & $\begin{array}{l}\text { ge } \\
\text { ne }\end{array}$ & accession number & species & Order & $\begin{array}{c}\text { Class/Subp } \\
\text { hylum }\end{array}$ & genome region & $\begin{array}{c}\text { genome } \\
\text { resource }\end{array}$ \\
\hline $\begin{array}{l}\text { Aasp_D } \\
\text { sx-like }\end{array}$ & $\begin{array}{l}\text { ds } x \\
- \\
\text { like }\end{array}$ & GAZQ02010078.1 & $\begin{array}{c}\text { Aretaon } \\
\text { asperrimus }\end{array}$ & $\begin{array}{l}\text { Phasmat } \\
\text { odea }\end{array}$ & $\begin{array}{c}\text { Ectognatha/ } \\
\text { Hexapoda }\end{array}$ & & \\
\hline$\underset{s \times 3}{\text { Afra_D }}$ & $\begin{array}{c}d s x \\
3\end{array}$ & AWC26109.1 & $\begin{array}{c}\text { Artemia } \\
\text { franciscana }\end{array}$ & $\begin{array}{c}\text { Anostrac } \\
a\end{array}$ & $\begin{array}{l}\text { Brachiopoda } \\
\text { /Crustacea }\end{array}$ & & \\
\hline$\underset{s \times 4}{\text { Afra_D }}$ & $\begin{array}{c}d s x \\
4\end{array}$ & AWC26111.1 & $\begin{array}{c}\text { Artemia } \\
\text { franciscana }\end{array}$ & $\begin{array}{c}\text { Anostrac } \\
a\end{array}$ & $\begin{array}{l}\text { Brachiopoda } \\
\text { /Crustacea }\end{array}$ & & \\
\hline $\begin{array}{l}\text { Annu_ } \\
\text { Dmrt99 } \\
\text { B }\end{array}$ & $\begin{array}{l}d m \\
r t 9 \\
9 B\end{array}$ & GATX01081132.1 & $\begin{array}{c}\text { Annulipalpia } \\
\text { sp. }\end{array}$ & $\begin{array}{l}\text { Trichopt } \\
\text { era }\end{array}$ & $\begin{array}{l}\text { Ectognatha/ } \\
\text { Hexapoda }\end{array}$ & & \\
\hline $\begin{array}{l}\text { Annu_- } \\
\text { Dsx }\end{array}$ & $d s x$ & GATX01084595.1 & $\begin{array}{c}\text { Annulipalpia } \\
\text { sp. }\end{array}$ & $\begin{array}{l}\text { Trichopt } \\
\text { era }\end{array}$ & $\begin{array}{l}\text { Ectognatha/ } \\
\text { Hexapoda }\end{array}$ & & \\
\hline $\begin{array}{c}\text { Aros_D } \\
\text { sx }\end{array}$ & $d s x$ & XP_012262263.1 & Athalia rosae & $\begin{array}{l}\text { Hymeno } \\
\text { ptera }\end{array}$ & $\begin{array}{c}\text { Ectognatha/ } \\
\text { Hexapoda }\end{array}$ & & \\
\hline $\begin{array}{l}\text { Baet_D } \\
\text { sx-like }\end{array}$ & $\begin{array}{l}d s x \\
- \\
\text { like }\end{array}$ & GATU02014641.1 & Baetis sp. & $\begin{array}{l}\text { Ephemer } \\
\text { optera }\end{array}$ & $\begin{array}{l}\text { Ectognatha/ } \\
\text { Hexapoda }\end{array}$ & & \\
\hline $\begin{array}{c}\text { Bdor_D } \\
\text { sx }\end{array}$ & $d s x$ & AАB99948.1 & $\begin{array}{c}\text { Bactrocera } \\
\text { dorsalis }\end{array}$ & Diptera & $\begin{array}{c}\text { Ectognatha/ } \\
\text { Hexapoda }\end{array}$ & & \\
\hline $\begin{array}{c}\text { Bger_D } \\
\text { sx }\end{array}$ & $d s x$ & PSN43312.1 & $\begin{array}{c}\text { Blattella } \\
\text { germanica }\end{array}$ & $\begin{array}{c}\text { Dictyopt } \\
\text { era }\end{array}$ & $\begin{array}{c}\text { Ectognatha/ } \\
\text { Hexapoda }\end{array}$ & & \\
\hline $\begin{array}{l}\text { Bhye_D } \\
\text { sx }\end{array}$ & $d s x$ & GAYK02032082.1 & $\begin{array}{c}\text { Boreus } \\
\text { hyemalis }\end{array}$ & $\begin{array}{l}\text { Mecopte } \\
\text { ra }\end{array}$ & $\begin{array}{l}\text { Ectognatha/ } \\
\text { Hexapoda }\end{array}$ & & \\
\hline $\begin{array}{l}\text { Bmor } \\
\text { Dmrt11 } \\
E\end{array}$ & $\begin{array}{l}d m \\
r t 1 \\
1 E\end{array}$ & XP_004930266.1 & Bombyx mori & $\begin{array}{l}\text { Lepidopt } \\
\text { era }\end{array}$ & $\begin{array}{l}\text { Ectognatha/ } \\
\text { Hexapoda }\end{array}$ & & \\
\hline $\begin{array}{l}\text { Bmor_ } \\
\text { Dmrt93 } \\
\text { B }\end{array}$ & $\begin{array}{l}d m \\
r t 9 \\
3 B\end{array}$ & XP_004932028.3 & Bombyx mori & $\begin{array}{l}\text { Lepidopt } \\
\text { era }\end{array}$ & $\begin{array}{c}\text { Ectognatha/ } \\
\text { Hexapoda }\end{array}$ & & \\
\hline $\begin{array}{l}\text { Bmor } \\
\text { Dmrt99 } \\
\text { B }\end{array}$ & $\begin{array}{l}d m \\
r t 9 \\
9 B\end{array}$ & XP_004924389.2 & Bombyx mori & $\begin{array}{l}\text { Lepidopt } \\
\text { era }\end{array}$ & $\begin{array}{l}\text { Ectognatha/ } \\
\text { Hexapoda }\end{array}$ & & \\
\hline $\begin{array}{l}\text { Bmor_- } \\
\text { Dsx }\end{array}$ & $d s x$ & XP_012544211.1 & Bombyx mori & $\begin{array}{l}\text { Lepidopt } \\
\text { era }\end{array}$ & $\begin{array}{l}\text { Ectognatha/ } \\
\text { Hexapoda }\end{array}$ & & \\
\hline $\begin{array}{l}\text { Bmut } \\
\text { Dmrt } 1\end{array}$ & $\begin{array}{l}d m \\
r t 1\end{array}$ & ELR53308.1 & Bos mutus & $\begin{array}{c}\text { Cetartiod } \\
\text { actyla }\end{array}$ & $\begin{array}{c}\text { Mammalia/V } \\
\text { ertebrata }\end{array}$ & & \\
\hline $\begin{array}{c}\text { Btau_D } \\
\text { mrt2 }\end{array}$ & $\begin{array}{l}d m \\
r t 2\end{array}$ & XP_005210039.1 & Bos taurus & $\begin{array}{c}\text { Cetartiod } \\
\text { actyla }\end{array}$ & $\begin{array}{c}\text { Mammalia/V } \\
\text { ertebrata }\end{array}$ & & \\
\hline$\underset{x}{\text { Btry_Ds }}$ & $d s x$ & AAV85890.1 & $\begin{array}{c}\text { Bactrocera } \\
\text { tryoni }\end{array}$ & Diptera & $\begin{array}{l}\text { Ectognatha/ } \\
\text { Hexapoda }\end{array}$ & & \\
\hline $\begin{array}{l}\text { Caqu_- } \\
\text { Dsx }\end{array}$ & $d s x$ & CAQU003748-RA & $\begin{array}{l}\text { Catajapyx } \\
\text { aquilonaris }\end{array}$ & Diplura & $\begin{array}{c}\text { Entognatha/ } \\
\text { Hexapoda }\end{array}$ & & \\
\hline $\begin{array}{l}\text { Ccap_- } \\
\text { Dsx }\end{array}$ & $d s x$ & XP_012158607.1 & $\begin{array}{l}\text { Ceratitis } \\
\text { capitata }\end{array}$ & Diptera & $\begin{array}{l}\text { Entognatha/ } \\
\text { Hexapoda }\end{array}$ & & \\
\hline $\begin{array}{c}\text { Ccor_D } \\
\text { sx }\end{array}$ & $d s x$ & GATG02018436.1 & $\begin{array}{l}\text { Corydalus } \\
\text { cornutus }\end{array}$ & $\begin{array}{l}\text { Megalopt } \\
\text { era }\end{array}$ & $\begin{array}{c}\text { Ectognatha/ } \\
\text { Hexapoda }\end{array}$ & & \\
\hline $\begin{array}{l}\text { Ceut_D } \\
\text { mrt11E }\end{array}$ & $\begin{array}{l}d m \\
r t 1 \\
1 E\end{array}$ & GAUX02031275.1 & $\begin{array}{c}\text { Ceuthophilus } \\
\text { sp. }\end{array}$ & $\begin{array}{c}\text { Orthopte } \\
\text { ra }\end{array}$ & $\begin{array}{l}\text { Ectognatha/ } \\
\text { Hexapoda }\end{array}$ & & \\
\hline$\underset{x}{\text { Cfel_Ds }}$ & $d s x$ & GAYP02016500.1 & $\begin{array}{c}\text { Ctenocephali } \\
\text { des felis }\end{array}$ & $\begin{array}{l}\text { Siphona } \\
\text { ptera }\end{array}$ & $\begin{array}{l}\text { Ectognatha/ } \\
\text { Hexapoda }\end{array}$ & & \\
\hline $\begin{array}{c}\text { Cgal_D } \\
\text { sx }\end{array}$ & $d s x$ & GAWK02011923.1 & $\begin{array}{l}\text { Ceratophyllu } \\
\text { s gallinae }\end{array}$ & $\begin{array}{l}\text { Siphona } \\
\text { ptera }\end{array}$ & $\begin{array}{l}\text { Ectognatha/ } \\
\text { Hexapoda }\end{array}$ & & \\
\hline $\begin{array}{l}\text { Choo_ } \\
\text { Dmrt11 } \\
\text { E }\end{array}$ & $\begin{array}{l}d m \\
r t 1 \\
1 E\end{array}$ & NQII01002646.1 & $\begin{array}{c}\text { Clitarchus } \\
\text { hookeri }\end{array}$ & $\begin{array}{c}\text { Phasmat } \\
\text { odea }\end{array}$ & $\begin{array}{c}\text { Ectognatha/ } \\
\text { Hexapoda }\end{array}$ & & \\
\hline $\begin{array}{l}\text { Choo- } \\
\text { Dsx-like }\end{array}$ & $\begin{array}{l}d s x \\
- \\
\text { like }\end{array}$ & NQII01000109.1 & $\begin{array}{c}\text { Clitarchus } \\
\text { hookeri }\end{array}$ & $\begin{array}{c}\text { Phasmat } \\
\text { odea }\end{array}$ & $\begin{array}{c}\text { Ectognatha/ } \\
\text { Hexapoda }\end{array}$ & & \\
\hline $\begin{array}{c}\text { Dcar_D } \\
\text { sx1 }\end{array}$ & $d s x$ & AIL 86779.1 & $\begin{array}{c}\text { Daphnia } \\
\text { carina }\end{array}$ & $\begin{array}{l}\text { Diplostra } \\
\text { ca }\end{array}$ & $\begin{array}{l}\text { Brachiopoda } \\
\text { /Crustacea }\end{array}$ & & \\
\hline$\underset{s \times 2}{\text { Dcar_D }}$ & $\begin{array}{c}d s x \\
2\end{array}$ & AIL86780.1 & $\begin{array}{c}\text { Daphnia } \\
\text { carina }\end{array}$ & $\begin{array}{c}\text { Diplostra } \\
\text { ca }\end{array}$ & $\begin{array}{l}\text { Brachiopoda } \\
\text { /Crustacea }\end{array}$ & & \\
\hline$\underset{\mathrm{sx1}}{\text { Dgal_D }}$ & $\begin{array}{c}d s x \\
1\end{array}$ & BAM33609.1 & $\begin{array}{l}\text { Daphnia } \\
\text { galeata }\end{array}$ & $\begin{array}{l}\text { Diplostra } \\
\text { ca }\end{array}$ & $\begin{array}{l}\text { Brachiopoda } \\
\text { /Crustacea }\end{array}$ & & \\
\hline$\underset{s \times 2}{\text { Dgal_D }}$ & $\begin{array}{c}d s x \\
2\end{array}$ & BAM33610.1 & $\begin{array}{l}\text { Daphnia } \\
\text { galeata }\end{array}$ & $\begin{array}{c}\text { Diplostra } \\
\text { ca }\end{array}$ & $\begin{array}{l}\text { Brachiopoda } \\
\text { /Crustacea }\end{array}$ & & \\
\hline $\begin{array}{l}\text { Dmag_ } \\
\text { Dmrt11 } \\
\mathrm{E}\end{array}$ & $\begin{array}{c}d m \\
r t 1 \\
1 e\end{array}$ & BAG12871.1 & $\begin{array}{c}\text { Daphnia } \\
\text { magna }\end{array}$ & $\begin{array}{l}\text { Diplostra } \\
\text { ca }\end{array}$ & $\begin{array}{l}\text { Brachiopoda } \\
\text { /Crustacea }\end{array}$ & & \\
\hline
\end{tabular}


bioRxiv preprint doi: https://doi.org/10.1101/2021.08.02.454784; this version posted August 5, 2021. The copyright holder for this preprint (which was not certified by peer review) is the author/funder, who has granted bioRxiv a license to display the preprint in perpetuity. It is made available under aCC-BY 4.0 International license.

\begin{tabular}{|c|c|c|c|c|c|c|c|}
\hline $\begin{array}{l}\text { Dmag }_{1} \\
\text { Dmrt93 } \\
\quad \text { B }\end{array}$ & $\begin{array}{l}d m \\
r t 9 \\
3 b\end{array}$ & BAG12872.1 & $\begin{array}{c}\text { Daphnia } \\
\text { magna }\end{array}$ & $\begin{array}{c}\text { Diplostra } \\
\text { ca }\end{array}$ & $\begin{array}{l}\text { Brachiopoda } \\
\text { /Crustacea }\end{array}$ & & \\
\hline $\begin{array}{l}\text { Dmag }_{-} \\
\text {Dmrt99 } \\
\text { B }\end{array}$ & $\begin{array}{l}d m \\
r t 9 \\
9 b\end{array}$ & BAG12873.1 & $\begin{array}{c}\text { Daphnia } \\
\text { magna }\end{array}$ & $\begin{array}{l}\text { Diplostra } \\
\text { ca }\end{array}$ & $\begin{array}{l}\text { Brachiopoda } \\
\text { /Crustacea }\end{array}$ & & \\
\hline $\begin{array}{c}\text { Dmag_ }_{\text {Dsx1 }} \\
\text { Den }\end{array}$ & $\begin{array}{c}d s x \\
1\end{array}$ & BAJ78307.1 & $\begin{array}{c}\text { Daphnia } \\
\text { magna }\end{array}$ & $\begin{array}{c}\text { Diplostra } \\
\text { ca }\end{array}$ & $\begin{array}{l}\text { Brachiopoda } \\
\text { /Crustacea }\end{array}$ & & \\
\hline $\begin{array}{l}\text { Dmag_ }_{\text {Dsx2 }}\end{array}$ & $\begin{array}{c}d s x \\
2\end{array}$ & BAJ78309.1 & $\begin{array}{c}\text { Daphnia } \\
\text { magna }\end{array}$ & $\begin{array}{l}\text { Diplostra } \\
\text { ca }\end{array}$ & $\begin{array}{l}\text { Brachiopoda } \\
\text { /Crustacea }\end{array}$ & & \\
\hline $\begin{array}{l}\text { Dmel__ } \\
\text { Dmrt11 } \\
\text { E }\end{array}$ & $\begin{array}{l}d m \\
r t 1 \\
1 e\end{array}$ & NP_511146.2 & $\begin{array}{l}\text { Drosophila } \\
\text { melanogaster }\end{array}$ & Diptera & $\begin{array}{l}\text { Ectognatha/ } \\
\text { Hexapoda }\end{array}$ & & \\
\hline $\begin{array}{l}\text { Dmel__ } \\
\text { Dmrt93 } \\
\text { B }\end{array}$ & $\begin{array}{l}d m \\
r t 9 \\
3 b\end{array}$ & NP_524428.1 & $\begin{array}{l}\text { Drosophila } \\
\text { melanogaster }\end{array}$ & Diptera & $\begin{array}{c}\text { Ectognatha/ } \\
\text { Hexapoda }\end{array}$ & & \\
\hline $\begin{array}{l}\text { Dmel_ } \\
\text { Dmrt99 } \\
\text { B }\end{array}$ & $\begin{array}{l}d m \\
r t 9 \\
9 b\end{array}$ & NP_524549.1 & $\begin{array}{l}\text { Drosophila } \\
\text { melanogaster }\end{array}$ & Diptera & $\begin{array}{l}\text { Ectognatha/ } \\
\text { Hexapoda }\end{array}$ & & \\
\hline $\begin{array}{c}\text { Dmel_ } \\
\text { Dsx }\end{array}$ & $d s x$ & NP_731197.1 & $\begin{array}{l}\text { Drosophila } \\
\text { melanogaster }\end{array}$ & Diptera & $\begin{array}{l}\text { Ectognatha/ } \\
\text { Hexapoda }\end{array}$ & & \\
\hline$\underset{\text { sxi } 1}{\text { Dpul_D }}$ & $\begin{array}{c}d s x \\
1\end{array}$ & AGJ52190.1 & $\begin{array}{c}\text { Daphnia } \\
\text { pulex }\end{array}$ & $\begin{array}{l}\text { Diplostra } \\
\text { ca }\end{array}$ & $\begin{array}{l}\text { Brachiopoda } \\
\text { /Crustacea }\end{array}$ & & \\
\hline $\begin{array}{l}\text { Dpul_D } \\
\text { sx2 }\end{array}$ & $\begin{array}{c}d s x \\
2\end{array}$ & BAM33608.1 & $\begin{array}{l}\text { Daphnia } \\
\text { pulex }\end{array}$ & $\begin{array}{c}\text { Diplostra } \\
\text { ca }\end{array}$ & $\begin{array}{l}\text { Brachiopoda } \\
\text { /Crustacea }\end{array}$ & & \\
\hline$\underset{\text { mrt-1 }}{\text { Drer_D }}$ & $\begin{array}{l}d m \\
r t 1\end{array}$ & AAQ04555.1 & Danio rerio & $\begin{array}{l}\text { Cyprinifo } \\
\text { rmes }\end{array}$ & $\begin{array}{l}\text { Actinopteryg } \\
\text { ii/Vertebrata }\end{array}$ & & \\
\hline $\begin{array}{l}\text { Drer_D } \\
\text { mrt2 }\end{array}$ & $\begin{array}{l}d m \\
r t 2\end{array}$ & NP_571027.1 & Danio rerio & $\begin{array}{l}\text { Cyprinifo } \\
\text { rmes }\end{array}$ & $\begin{array}{l}\text { Actinopteryg } \\
\text { ii/Vertebrata }\end{array}$ & & \\
\hline $\begin{array}{l}\text { Edan_d } \\
\text { mrt11E }\end{array}$ & $\begin{array}{l}d m \\
r t 1 \\
1 E\end{array}$ & EDAN008414-RA & $\begin{array}{l}\text { Ephemera } \\
\text { danica }\end{array}$ & $\begin{array}{l}\text { Ephemer } \\
\text { optera }\end{array}$ & $\begin{array}{l}\text { Ectognatha/ } \\
\text { Hexapoda }\end{array}$ & & \\
\hline $\begin{array}{l}\text { Edan_d } \\
\text { mrt93B }\end{array}$ & $\begin{array}{l}d m \\
r t 9 \\
3 B\end{array}$ & EDAN004527-RA & $\begin{array}{l}\text { Ephemera } \\
\text { danica }\end{array}$ & $\begin{array}{l}\text { Ephemer } \\
\text { optera }\end{array}$ & $\begin{array}{l}\text { Ectognatha/ } \\
\text { Hexapoda }\end{array}$ & & \\
\hline $\begin{array}{l}\text { Edan_d } \\
\text { mrt99B }\end{array}$ & $\begin{array}{l}d m \\
r t 9 \\
9 B\end{array}$ & EDAN010669-RA & $\begin{array}{l}\text { Ephemera } \\
\text { danica }\end{array}$ & $\begin{array}{c}\text { Ephemer } \\
\text { optera }\end{array}$ & $\begin{array}{c}\text { Ectognatha/ } \\
\text { Hexapoda }\end{array}$ & & \\
\hline $\begin{array}{l}\text { Edan } \\
\text { Dsx-like }\end{array}$ & $\begin{array}{l}d s x \\
- \\
\text { like }\end{array}$ & & $\begin{array}{c}\text { Ephemera } \\
\text { danica }\end{array}$ & $\begin{array}{l}\text { Ephemer } \\
\text { optera }\end{array}$ & $\begin{array}{c}\text { Ectognatha/ } \\
\text { Hexapoda }\end{array}$ & $\underset{3}{\text { ephdan_Scaffold2 }}$ & i5k \\
\hline $\begin{array}{l}\text { Eins_D } \\
\text { sx-like }\end{array}$ & $\begin{array}{l}d s x \\
- \\
\text { like }\end{array}$ & GCCL01024227.1 & $\begin{array}{l}\text { Ecdyonurus } \\
\text { insignis }\end{array}$ & $\begin{array}{l}\text { Ephemer } \\
\text { optera }\end{array}$ & $\begin{array}{l}\text { Ectognatha/ } \\
\text { Hexapoda }\end{array}$ & & \\
\hline $\begin{array}{c}\text { Enos_D } \\
\text { sx }\end{array}$ & $d s x$ & GAXW02019001.1 & $\begin{array}{c}\text { Euroleon } \\
\text { nostras }\end{array}$ & $\begin{array}{l}\text { Neuropte } \\
\text { ra }\end{array}$ & $\begin{array}{l}\text { Ectognatha/ } \\
\text { Hexapoda }\end{array}$ & & \\
\hline $\begin{array}{l}\text { Epen_- } \\
\text { Dsx }\end{array}$ & $d s x$ & GAWT02033840.1 & $\begin{array}{l}\text { Empusa } \\
\text { pennata }\end{array}$ & $\begin{array}{c}\text { Mantode } \\
\text { a }\end{array}$ & $\begin{array}{l}\text { Ectognatha/ } \\
\text { Hexapoda }\end{array}$ & & \\
\hline$\underset{\text { sx }}{\text { Esup_D }}$ & $d s x$ & GAVW02000373.1 & $\begin{array}{l}\text { Epiophlebia } \\
\text { superstes }\end{array}$ & Odonata & $\begin{array}{c}\text { Ectognatha/ } \\
\text { Hexapoda }\end{array}$ & & \\
\hline $\begin{array}{l}\text { Eury_D } \\
\text { mrt11E }\end{array}$ & $\begin{array}{l}d m \\
r t 1 \\
1 E\end{array}$ & GAZG02011227.1 & $\begin{array}{l}\text { Eurylophella } \\
\text { sp. }\end{array}$ & $\begin{array}{l}\text { Ephemer } \\
\text { optera }\end{array}$ & $\begin{array}{l}\text { Ectognatha/ } \\
\text { Hexapoda }\end{array}$ & & \\
\hline $\begin{array}{l}\text { Eury_D } \\
\text { sx-like }\end{array}$ & $\begin{array}{l}d s x \\
- \\
\text { like }\end{array}$ & GAZG02000044.1 & $\begin{array}{l}\text { Eurylophella } \\
\text { sp. }\end{array}$ & $\begin{array}{c}\text { Ephemer } \\
\text { optera }\end{array}$ & $\begin{array}{c}\text { Ectognatha/ } \\
\text { Hexapoda }\end{array}$ & & \\
\hline $\begin{array}{c}\text { Focc_D } \\
\text { sx }\end{array}$ & $d s x$ & FOCC007514-RA & $\begin{array}{l}\text { Frankliniella } \\
\text { occidentalis }\end{array}$ & $\begin{array}{c}\text { Thysano } \\
\text { ptera }\end{array}$ & $\begin{array}{c}\text { Ectognatha/ } \\
\text { Hexapoda }\end{array}$ & & \\
\hline $\begin{array}{c}\text { Gcor_D } \\
\text { sx }\end{array}$ & $d s x$ & BAW32683.1 & $\begin{array}{c}\text { Gnatocerus } \\
\text { cornutus }\end{array}$ & $\begin{array}{c}\text { Coleopte } \\
\text { ra }\end{array}$ & $\begin{array}{l}\text { Ectognatha/ } \\
\text { Hexapoda }\end{array}$ & & \\
\hline $\begin{array}{l}\text { Harm_- } \\
\text { Dsx }\end{array}$ & $d s x$ & XP_021192052.1 & $\begin{array}{c}\text { Helicoverpa } \\
\text { armigera }\end{array}$ & $\begin{array}{l}\text { Lepidopt } \\
\text { era }\end{array}$ & $\begin{array}{l}\text { Ectognatha/ } \\
\text { Hexapoda }\end{array}$ & & \\
\hline $\begin{array}{l}\text { Hdeu_- } \\
\text { Dsx }\end{array}$ & $d s x$ & $\begin{array}{l}\text { maker-scaffold37size976698- } \\
\text { augustus-gene-4.5-mRNA-1 }\end{array}$ & $\begin{array}{l}\text { Holacanthella } \\
\text { duospinosa }\end{array}$ & $\begin{array}{l}\text { Collemb } \\
\text { ola }\end{array}$ & $\begin{array}{l}\text { Entognatha/ } \\
\text { Hexapoda }\end{array}$ & & i5k \\
\hline $\begin{array}{l}\text { Hydr_D } \\
\text { sx }\end{array}$ & $d s x$ & GAVM02014074.1 & $\begin{array}{l}\text { Hydroptila } \\
\text { sp. }\end{array}$ & $\begin{array}{l}\text { Trichopt } \\
\text { era }\end{array}$ & $\begin{array}{l}\text { Ectognatha/ } \\
\text { Hexapoda }\end{array}$ & & \\
\hline $\begin{array}{l}\text { Ibic_Ds } \\
\text { x-like }\end{array}$ & $\begin{array}{l}d s x \\
- \\
\text { like }\end{array}$ & GAXA02007870.1 & $\begin{array}{l}\text { Isonychia } \\
\text { bicolor }\end{array}$ & $\begin{array}{l}\text { Ephemer } \\
\text { optera }\end{array}$ & $\begin{array}{l}\text { Ectognatha/ } \\
\text { Hexapoda }\end{array}$ & & \\
\hline$\underset{x}{\text { Icra_Ds }}$ & $d s x$ & GAZH02011000.1 & $\begin{array}{l}\text { Inocellia } \\
\text { crassicornis }\end{array}$ & $\begin{array}{l}\text { Raphidio } \\
\text { ptera }\end{array}$ & $\begin{array}{l}\text { Ectognatha/ } \\
\text { Hexapoda }\end{array}$ & & \\
\hline $\begin{array}{l}\text { Lcup_D } \\
\text { mrt11E }\end{array}$ & $\begin{array}{l}d m \\
r t 1 \\
1 E\end{array}$ & XP_023291847.1 & $\begin{array}{l}\text { Lucilia } \\
\text { cuprina }\end{array}$ & Diptera & $\begin{array}{c}\text { Ectognatha/ } \\
\text { Hexapoda }\end{array}$ & & i5k \\
\hline $\begin{array}{l}\text { Lcup_D } \\
\text { mrt93B }\end{array}$ & $\begin{array}{l}d m \\
r t 9 \\
3 B\end{array}$ & XP_023302612.1 & $\begin{array}{l}\text { Lucilia } \\
\text { cuprina }\end{array}$ & Diptera & $\begin{array}{l}\text { Ectognatha/ } \\
\text { Hexapoda }\end{array}$ & & \\
\hline $\begin{array}{l}\text { Lcup_D } \\
\text { mrt99B }\end{array}$ & $\begin{array}{l}d m \\
r t 9 \\
9 B\end{array}$ & XP_023308885.1 & $\begin{array}{l}\text { Lucilia } \\
\text { cuprina }\end{array}$ & Diptera & $\begin{array}{c}\text { Ectognatha/ } \\
\text { Hexapoda }\end{array}$ & & \\
\hline$\underset{\text { sx }}{\text { Lcup_D }}$ & $d s x$ & ADG37648.1 & $\begin{array}{l}\text { Lucilia } \\
\text { cuprina }\end{array}$ & Diptera & $\begin{array}{l}\text { Ectognatha/ } \\
\text { Hexapoda }\end{array}$ & & \\
\hline$\underset{x}{\text { Lful_Ds }}$ & $d s x$ & LFUL018497-RA & Ladona fulva & Odonata & $\begin{array}{l}\text { Ectognatha/ } \\
\text { Hexapoda }\end{array}$ & & \\
\hline
\end{tabular}


bioRxiv preprint doi: https://doi.org/10.1101/2021.08.02.454784; this version posted August 5, 2021. The copyright holder for this preprint (which was not certified by peer review) is the author/funder, who has granted bioRxiv a license to display the preprint in perpetuity. It is made available under aCC-BY 4.0 International license.

\begin{tabular}{|c|c|c|c|c|c|c|c|}
\hline$\underset{\text { sx }}{\text { Lmig_D }}$ & $d s x$ & & $\begin{array}{l}\text { Locusta } \\
\text { migratoria }\end{array}$ & $\begin{array}{l}\text { Orthopte } \\
\text { ra }\end{array}$ & $\begin{array}{l}\text { Ectognatha/ } \\
\text { Hexapoda }\end{array}$ & scaffold3427 & $\mathrm{NCBI}$ \\
\hline $\begin{array}{l}\text { Mdom } \\
\text { Dmrt11 } \\
\text { E }\end{array}$ & $\begin{array}{l}d m \\
r t 1 \\
1 E\end{array}$ & XP_019890834.1 & $\begin{array}{c}\text { Musca } \\
\text { domestica }\end{array}$ & Diptera & $\begin{array}{c}\text { Ectognatha/ } \\
\text { Hexapoda }\end{array}$ & & \\
\hline $\begin{array}{l}\text { Mdom } \\
\text { Dmrt99 } \\
\text { B }\end{array}$ & $\begin{array}{l}d m \\
r t 9 \\
9 B\end{array}$ & XP_005186857.1 & $\begin{array}{c}\text { Musca } \\
\text { domestica }\end{array}$ & Diptera & $\begin{array}{l}\text { Ectognatha/ } \\
\text { Hexapoda }\end{array}$ & & \\
\hline $\begin{array}{c}\text { Mdom }_{\text {Dsx }} \\
\text { D }\end{array}$ & $d s x$ & AAR23813.1 & $\begin{array}{c}\text { Musca } \\
\text { domestica }\end{array}$ & Diptera & $\begin{array}{l}\text { Ectognatha/ } \\
\text { Hexapoda }\end{array}$ & & \\
\hline $\begin{array}{l}\text { Mext_D } \\
\text { mrt99B }\end{array}$ & $\begin{array}{l}d m \\
r t 9 \\
9 B\end{array}$ & Medex_00095964-RA & $\begin{array}{l}\text { Medauroidea } \\
\text { extradentata }\end{array}$ & $\begin{array}{c}\text { Phasmat } \\
\text { odea }\end{array}$ & $\begin{array}{l}\text { Ectognatha/ } \\
\text { Hexapoda }\end{array}$ & & \\
\hline $\begin{array}{c}\text { Mext_D } \\
\text { sx }\end{array}$ & $d s x$ & & $\begin{array}{l}\text { Medauroidea } \\
\text { extradentata }\end{array}$ & $\begin{array}{l}\text { Phasmat } \\
\text { odea }\end{array}$ & $\begin{array}{l}\text { Ectognatha/ } \\
\text { Hexapoda }\end{array}$ & $\begin{array}{c}\text { PNEQ01023967.1 } \\
\text { [32614-32324] }\end{array}$ & i5k \\
\hline $\begin{array}{l}\text { Mext_D } \\
\text { sx-like }\end{array}$ & $\begin{array}{l}d s x \\
- \\
\text { like }\end{array}$ & Medex_00099178-RA & $\begin{array}{l}\text { Medauroidea } \\
\text { extradentata }\end{array}$ & $\begin{array}{l}\text { Phasmat } \\
\text { odea }\end{array}$ & $\begin{array}{l}\text { Ectognatha/ } \\
\text { Hexapoda }\end{array}$ & $\begin{array}{c}\text { PNEQ01097711.1 } \\
\text { [2988-3275] }\end{array}$ & i5k \\
\hline $\begin{array}{c}\text { Mfas_D } \\
\text { sx }\end{array}$ & $d s x$ & GCNI01018035.1 & $\begin{array}{c}\text { Meroplius } \\
\text { fasciculatus }\end{array}$ & Diptera & $\begin{array}{l}\text { Ectognatha/ } \\
\text { Hexapoda }\end{array}$ & & \\
\hline$\underset{\mathrm{Dsx}}{\mathrm{Mmac}}$ & $d s x$ & ВАМ 33613.1 & $\begin{array}{c}\text { Moina } \\
\text { macropaene } \\
\text { us }\end{array}$ & $\begin{array}{l}\text { Diplostra } \\
\text { ca }\end{array}$ & $\begin{array}{l}\text { Brachiopoda } \\
\text { /Crustacea }\end{array}$ & & \\
\hline $\begin{array}{l}\text { Mmus_- } \\
\text { Dmrt1 }\end{array}$ & $\begin{array}{l}d m \\
r t 1\end{array}$ & AAO41736.1 & $\begin{array}{c}\text { Mus } \\
\text { musculus }\end{array}$ & Rodentia & $\begin{array}{c}\text { Mammalia/V } \\
\text { ertebrata }\end{array}$ & & \\
\hline $\begin{array}{c}\text { Mrel_D } \\
\text { sx }\end{array}$ & $d s x$ & GASW02021994.1 & $\begin{array}{l}\text { Mantis } \\
\text { religiosa }\end{array}$ & $\begin{array}{c}\text { Mantode } \\
\text { a }\end{array}$ & $\begin{array}{l}\text { Ectognatha/ } \\
\text { Hexapoda }\end{array}$ & & \\
\hline $\begin{array}{c}\text { Mviol_- } \\
\text { Dsx }\end{array}$ & $d s x$ & GATA02010186.1 & $\begin{array}{c}\text { Meloe } \\
\text { violaceus }\end{array}$ & $\begin{array}{c}\text { Coleopte } \\
\text { ra }\end{array}$ & $\begin{array}{l}\text { Ectognatha/ } \\
\text { Hexapoda }\end{array}$ & & \\
\hline $\begin{array}{c}\text { Ofur_D } \\
\text { sx }\end{array}$ & $d s x$ & AHF81635.1 & $\begin{array}{l}\text { Ostrinia } \\
\text { furnacalis }\end{array}$ & $\begin{array}{l}\text { Lepidopt } \\
\text { era }\end{array}$ & $\begin{array}{l}\text { Ectognatha/ } \\
\text { Hexapoda }\end{array}$ & & i5k \\
\hline$\underset{\text { sx }}{\text { Otau_D }}$ & $d s x$ & AEX92938.1 & $\begin{array}{c}\text { Onthophagus } \\
\text { taurus }\end{array}$ & $\begin{array}{c}\text { Coleopte } \\
\text { ra }\end{array}$ & $\begin{array}{l}\text { Ectognatha/ } \\
\text { Hexapoda }\end{array}$ & & \\
\hline $\begin{array}{c}\text { Ppra_D } \\
\text { sx }\end{array}$ & $d s x$ & GAVV02027199.1 & $\begin{array}{l}\text { Pseudomalla } \\
\text { da prasinus }\end{array}$ & $\begin{array}{l}\text { Neuropte } \\
\text { ra }\end{array}$ & $\begin{array}{l}\text { Ectognatha/ } \\
\text { Hexapoda }\end{array}$ & & \\
\hline $\begin{array}{l}\text { Psch_D } \\
\text { sx-like }\end{array}$ & $\begin{array}{l}d s x \\
- \\
\text { like }\end{array}$ & GAWJ02028457.1 & $\begin{array}{c}\text { Peruphasma } \\
\text { schultei }\end{array}$ & $\begin{array}{c}\text { Phasmat } \\
\text { odea }\end{array}$ & $\begin{array}{l}\text { Ectognatha/ } \\
\text { Hexapoda }\end{array}$ & & i5k \\
\hline $\begin{array}{l}\text { Smag }_{\text {D }} \\
\text { Dmrt99 } \\
\text { B }\end{array}$ & $\begin{array}{l}d m \\
r t 9 \\
9 b\end{array}$ & GEYQ01032489.1 & $\begin{array}{l}\text { Steganacaru } \\
\text { s magnus }\end{array}$ & Oribatida & $\begin{array}{l}\text { Arachnida/C } \\
\text { helicerata }\end{array}$ & & \\
\hline $\begin{array}{l}\text { Tcas_D } \\
\text { mrt93B }\end{array}$ & $\begin{array}{l}d m \\
r t 9 \\
3 B\end{array}$ & XP_008199135.1 & $\begin{array}{l}\text { Tribolium } \\
\text { castaneum }\end{array}$ & $\begin{array}{l}\text { Coleopte } \\
\text { ra }\end{array}$ & $\begin{array}{l}\text { Ectognatha/ } \\
\text { Hexapoda }\end{array}$ & & \\
\hline $\begin{array}{l}\text { Tcas_D } \\
\text { mrt99B }\end{array}$ & $\begin{array}{l}d m \\
r t 9 \\
9 B\end{array}$ & XP_975675.1 & $\begin{array}{l}\text { Tribolium } \\
\text { castaneum }\end{array}$ & $\begin{array}{l}\text { Coleopte } \\
\text { ra }\end{array}$ & $\begin{array}{l}\text { Ectognatha/ } \\
\text { Hexapoda }\end{array}$ & & \\
\hline $\begin{array}{c}\text { Tcas_D } \\
\text { sx }\end{array}$ & $d s x$ & NP_001345539.1 & $\begin{array}{l}\text { Tribolium } \\
\text { castaneum }\end{array}$ & $\begin{array}{c}\text { Coleopte } \\
\text { ra }\end{array}$ & $\begin{array}{l}\text { Ectognatha/ } \\
\text { Hexapoda }\end{array}$ & & \\
\hline $\begin{array}{c}\text { Tcri_Ds } \\
\text { x-like }\end{array}$ & $\begin{array}{l}d s x \\
- \\
\text { like }\end{array}$ & GAVX02010884.1 & $\begin{array}{l}\text { Timema } \\
\text { cristinae }\end{array}$ & $\begin{array}{c}\text { Phasmat } \\
\text { odea }\end{array}$ & $\begin{array}{l}\text { Ectognatha/ } \\
\text { Hexapoda }\end{array}$ & & \\
\hline$\underset{s x}{\text { Tdic_D }}$ & $d s x$ & BАМ 93340.1 & $\begin{array}{l}\text { Trypoxylus } \\
\text { dichotomus }\end{array}$ & $\begin{array}{l}\text { Coleopte } \\
\text { ra }\end{array}$ & $\begin{array}{l}\text { Ectognatha/ } \\
\text { Hexapoda }\end{array}$ & & \\
\hline $\begin{array}{l}\text { Tdom } \\
\text { Dmrt11 } \\
\text { E }\end{array}$ & $\begin{array}{l}d m \\
r t 1 \\
1 E\end{array}$ & this study & $\begin{array}{l}\text { Thermobia } \\
\text { domestica }\end{array}$ & $\begin{array}{l}\text { Zygento } \\
\text { ma }\end{array}$ & $\begin{array}{c}\text { Ectognatha/ } \\
\text { Hexapoda }\end{array}$ & $\begin{array}{c}\text { scaffold42162_cov } \\
39[159031- \\
158906]\end{array}$ & \\
\hline $\begin{array}{l}\text { Tdom } \\
\text { Dmrt93 } \\
\text { B }\end{array}$ & $\begin{array}{l}d m \\
r t 9 \\
3 B\end{array}$ & this study & $\begin{array}{l}\text { Thermobia } \\
\text { domestica }\end{array}$ & $\begin{array}{l}\text { Zygento } \\
\text { ma }\end{array}$ & $\begin{array}{l}\text { Ectognatha/ } \\
\text { Hexapoda }\end{array}$ & $\begin{array}{c}\text { scaffold1624327_c } \\
\text { ov47 [121390- } \\
121265]\end{array}$ & \\
\hline $\begin{array}{l}\text { Tdom } \\
\text { Dmrt99 } \\
\text { B }\end{array}$ & $\begin{array}{l}d m \\
r t 9 \\
9 B\end{array}$ & this study & $\begin{array}{l}\text { Thermobia } \\
\text { domestica }\end{array}$ & $\begin{array}{l}\text { Zygento } \\
\text { ma }\end{array}$ & $\begin{array}{l}\text { Ectognatha/ } \\
\text { Hexapoda }\end{array}$ & $\begin{array}{c}\text { scaffold21840_cov } \\
24 \text { [214972- } \\
214787]\end{array}$ & \\
\hline $\begin{array}{c}\text { Tdom } \\
\text { Dsx }\end{array}$ & $d s x$ & this study & $\begin{array}{l}\text { Thermobia } \\
\text { domestica }\end{array}$ & $\underset{\text { ma }}{\text { Zygento }}$ & $\begin{array}{l}\text { Ectognatha/ } \\
\text { Hexapoda }\end{array}$ & & \\
\hline $\begin{array}{l}\text { Tdom } \\
\text { Dsx-like }\end{array}$ & $\begin{array}{c}d s x \\
- \\
\text { like }\end{array}$ & this study & $\begin{array}{l}\text { Thermobia } \\
\text { domestica }\end{array}$ & $\begin{array}{l}\text { Zygento } \\
\text { ma }\end{array}$ & $\begin{array}{c}\text { Ectognatha/ } \\
\text { Hexapoda }\end{array}$ & $\begin{array}{c}\text { scaffold27567_cov } \\
49 \text { [365805- } \\
281362]\end{array}$ & \\
\hline $\begin{array}{l}\text { Tger_D } \\
\text { sx-like }\end{array}$ & $\begin{array}{l}d s x \\
- \\
\text { like }\end{array}$ & GASO02037568.1 & $\begin{array}{l}\text { Tricholepidio } \\
\text { n gertschi }\end{array}$ & $\begin{array}{l}\text { Zygento } \\
\text { ma }\end{array}$ & $\begin{array}{l}\text { Ectognatha/ } \\
\text { Hexapoda }\end{array}$ & & \\
\hline $\begin{array}{c}\text { Tsub_D } \\
\text { sx }\end{array}$ & $d s x$ & GASQ02027559.1 & $\begin{array}{l}\text { Tetrix } \\
\text { subulata }\end{array}$ & $\begin{array}{c}\text { Orthopte } \\
\text { ra }\end{array}$ & $\begin{array}{l}\text { Ectognatha/ } \\
\text { Hexapoda }\end{array}$ & & \\
\hline $\begin{array}{c}\text { Xant_D } \\
\text { sx }\end{array}$ & $d s x$ & GAUI02048130.1 & $\begin{array}{c}\text { Xanthostigm } \\
\text { a sp. }\end{array}$ & $\begin{array}{l}\text { Raphidio } \\
\text { ptera }\end{array}$ & $\begin{array}{c}\text { Ectognatha/ } \\
\text { Hexapoda }\end{array}$ & & \\
\hline$\underset{\text { mrt } 1}{\text { Xlae_D }}$ & $\begin{array}{l}d m \\
r t 1\end{array}$ & NP_001089969.1 & $\begin{array}{c}\text { Xenopus } \\
\text { laevis }\end{array}$ & Anura & $\begin{array}{c}\text { Amphibia/V } \\
\text { ertebrata }\end{array}$ & & \\
\hline$\underset{\text { mrt4 }}{\text { Xlae_D }}$ & $\begin{array}{l}d m \\
r t 4\end{array}$ & AAH70678.2 & $\begin{array}{l}\text { Xenopus } \\
\text { laevis }\end{array}$ & Anura & $\begin{array}{c}\text { Amphibia/V } \\
\text { ertebrata }\end{array}$ & & \\
\hline $\begin{array}{c}\text { Xlae_D } \\
\text { mrt5 }\end{array}$ & $\begin{array}{l}d m \\
r t 5\end{array}$ & AAI70166.1 & $\begin{array}{l}\text { Xenopus } \\
\text { laevis }\end{array}$ & Anura & $\begin{array}{l}\text { Amphibia/V } \\
\text { ertebrata }\end{array}$ & & \\
\hline
\end{tabular}


1099 Table 2. Results of RT-qPCR assay and Brunner-Munzel test. Significant levels are indicated by asterisks in significance column: $* P<0.05$,

$1100 * * P<0.01, * * * P<0.001$. n.s. means non-significance.

\begin{tabular}{|c|c|c|c|c|c|c|c|c|c|c|c|c|c|}
\hline \multirow{2}{*}{ experiment } & \multirow{2}{*}{ treatment } & \multirow{2}{*}{$\begin{array}{l}\text { sample } \\
\text { size }(N)\end{array}$} & \multicolumn{2}{|c|}{ median } & \multirow{2}{*}{$\begin{array}{c}\text { proportion of } \\
2^{-\Delta C t}\end{array}$} & \multirow{2}{*}{\multicolumn{2}{|c|}{$\begin{array}{l}95 \% \text { confidence } \\
\text { interval }\end{array}$}} & \multicolumn{3}{|c|}{ Brunner-Munzel test } & \multirow{2}{*}{$\begin{array}{l}P \text {-value adjusted } \\
\text { by Holm's method }\end{array}$} & \multirow{2}{*}{ significance } & \multirow{2}{*}{ graph \# } \\
\hline & & & $\Delta \mathrm{Ct}$ & $2^{-\Delta \mathrm{Ct}}$ & & & & statistics & df & $P$-value & & & \\
\hline \multirow{2}{*}{$\begin{array}{l}d s x \text { male-type } \\
\text { expression level }\end{array}$} & male & 12 & 8.59 & 2.66. E-03 & 1.00 & \multirow{2}{*}{0.83} & \multirow{2}{*}{1.07} & \multirow{2}{*}{8.25} & \multirow{2}{*}{12.82} & \multirow{2}{*}{ 1.75.E-06 } & \multirow{2}{*}{-} & \multirow{2}{*}{ *** } & \multirow{2}{*}{ Figure 1D } \\
\hline & female & 8 & 13.89 & 6.64.E-05 & 0.02 & & & & & & & & \\
\hline \multirow{2}{*}{$\begin{array}{l}d s x \text { female-type } \\
\text { expression level }\end{array}$} & male & 11 & 9.98 & 9.90.E-04 & 1.00 & \multirow{2}{*}{-0.01} & \multirow{2}{*}{0.01} & \multirow{2}{*}{-92.63} & \multirow{2}{*}{20.95} & \multirow{2}{*}{ 2.20.E-16 } & \multirow{2}{*}{-} & \multirow{2}{*}{ *** } & \multirow{2}{*}{ Figure 1D } \\
\hline & female & 12 & 5.77 & 1.83.E-02 & 18.47 & & & & & & & & \\
\hline \multirow{2}{*}{$\begin{array}{l}d s x \text {-like expression } \\
\text { level }\end{array}$} & male & 12 & 3.62 & 8.13.E-02 & 1.00 & \multirow{2}{*}{0.58} & \multirow{2}{*}{1.02} & & & & & & \\
\hline & female & 12 & 4.71 & 3.83.E-02 & 0.47 & & & 2.80 & 21.84 & $9.24 . E-03$ & - & $\ldots$ & Figure $1 \mathrm{E}$ \\
\hline & egfp & 12 & 7.50 & 5.52.E-03 & 1.00 & & & & & & & & \\
\hline $\begin{array}{l}d s x \text { expression } \\
\text { level in males }\end{array}$ & $d s \times$ all & 8 & 9.24 & 1.66.E-03 & 0.30 & 0.45 & 1.03 & 1.78 & 13.61 & 9.68.E-02 & 1.94.E-01 & n.s. & $\begin{array}{l}\text { Figure 1-figure } \\
\text { supplement } 3 \mathrm{~B}\end{array}$ \\
\hline & $d s x$-like & 10 & 7.14 & 7.10.E-03 & 1.29 & 0.07 & 0.57 & -1.54 & 17.40 & 1.43.E-01 & 1.43.E-01 & n.s. & \\
\hline & egfp & 12 & 7.50 & 5.52.E-03 & 1.00 & & & & & & & & \\
\hline $\begin{array}{l}\text { dsx expression } \\
\text { level in males } \\
\text { excluding outliers }\end{array}$ & $d s \times$ all & 7 & 9.32 & 1.57.E-03 & 0.28 & 0.64 & 1.05 & 3.64 & 13.87 & 2.73.E-03 & 5.45.E-03 & ** & $\begin{array}{l}\text { Figure 1-figure } \\
\text { supplement } 3 A\end{array}$ \\
\hline & $d s x$-like & 10 & 7.14 & 7.10.E-03 & 1.29 & 0.07 & 0.57 & -1.54 & 17.40 & 1.43.E-01 & 1.43.E-01 & n.s. & \\
\hline & egfp & 10 & 5.18 & 2.76.E-02 & 1.00 & & & & & & & & \\
\hline $\begin{array}{l}d s x \text { expression } \\
\text { level in females }\end{array}$ & $d s \times$ all & 17 & 6.23 & 1.33.E-02 & 0.48 & 0.57 & 0.99 & 2.78 & 16.21 & 1.33.E-02 & 2.65.E-02 & * & $\begin{array}{l}\text { Figure 1-figure } \\
\text { supplement } 3 \mathrm{~A}\end{array}$ \\
\hline & $d s x$-like & 9 & 5.17 & 2.78.E-02 & 1.01 & 0.20 & 0.82 & 0.08 & 15.38 & 9.40.E-01 & 9.40.E-01 & n.s. & \\
\hline & egfp & 12 & 5.72 & 1.95.E-02 & 1.00 & & & & & & & & \\
\hline $\begin{array}{l}d s x \text {-like expression } \\
\text { level in males }\end{array}$ & $d s \times$ all & 8 & 6.17 & 1.39.E-02 & 0.72 & 0.50 & 0.98 & 2.08 & 17.99 & 5.19.E-02 & 5.19.E-02 & n.s. & $\begin{array}{l}\text { Figure 1-figure } \\
\text { supplement } 3 \mathrm{~A}\end{array}$ \\
\hline & $d s x$-like & 10 & 10.17 & 8.68.E-04 & 0.04 & 1.00 & 1.00 & Inf & $\mathrm{NaN}$ & 2.20.E-16 & 4.40.E-16 & *** & \\
\hline & egfp & 10 & 6.08 & 1.49.E-02 & 1.00 & & & & & & & & \\
\hline $\begin{array}{l}d s x \text {-like expression } \\
\text { level in females }\end{array}$ & $d s x$ all & 17 & 6.31 & 1.26.E-02 & 0.85 & 0.47 & 0.93 & 1.82 & 16.18 & 8.76.E-02 & 8.76.E-02 & n.s. & $\begin{array}{l}\text { Figure 1-figure } \\
\text { supplement } 3 \mathrm{~A}\end{array}$ \\
\hline & $d s x$-like & 9 & 11.58 & 3.27.E-04 & 0.02 & 1.00 & 1.00 & Inf & $\mathrm{NaN}$ & 2.20.E-16 & 4.40.E-16 & *** & \\
\hline
\end{tabular}




\begin{tabular}{|c|c|c|c|c|c|c|c|c|c|c|c|c|c|}
\hline \multirow{4}{*}{$\begin{array}{l}\text { vitellogenin-1 } \\
\text { expression level in } \\
\text { males }\end{array}$} & egfp & 5 & 15.00 & 3.06.E-05 & 1.00 & & & & & & & & \multirow{4}{*}{ Figure 4D } \\
\hline & $d s \times$ all & 9 & 4.42 & 4.68.E-02 & 1530.72 & -0.05 & 0.09 & -15.20 & 10.67 & 1.44.E-08 & 2.87.E-08 & 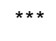 & \\
\hline & $d s x$-like & 7 & 10.18 & 8.62.E-04 & 28.18 & -0.12 & 0.41 & -3.09 & 8.42 & 1.39.E-02 & 1.39.E-02 & * & \\
\hline & $d s x+d s x$-like & 9 & 4.28 & 5.14.E-02 & 1678.94 & 0.00 & 0.00 & $-\ln f$ & $\mathrm{NaN}$ & 2.20.E-16 & 6.60.E-16 & 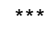 & \\
\hline \multirow{4}{*}{$\begin{array}{l}\text { vitellogenin-2 } \\
\text { expression level in } \\
\text { males }\end{array}$} & egfp & 3 & 16.76 & 9.01.E-06 & 1.00 & & & & & & & & \multirow{4}{*}{ Figure 4[} \\
\hline & $d s x$ all & 8 & 11.24 & 4.13.E-04 & 45.89 & 0.00 & 0.00 & $-\operatorname{Inf}$ & $\mathrm{NaN}$ & 2.20.E-16 & 6.60.E-16 & $* \star \star \star$ & \\
\hline & $d s x$-like & 5 & 15.48 & 2.19.E-05 & 2.43 & -0.24 & 0.51 & -2.46 & 5.56 & 5.24.E-02 & 6.19.E-01 & n.s. & \\
\hline & $d s x+d s x$-like & 8 & 10.64 & 6.27.E-04 & 28.64 & 0.00 & 0.00 & $-\operatorname{lnf}$ & $\mathrm{NaN}$ & 2.20.E-16 & 6.60.E-16 & $* * *$ & \\
\hline \multirow{4}{*}{$\begin{array}{c}\text { vitellogenin-3 } \\
\text { expression level in } \\
\text { males }\end{array}$} & egfp & 10 & 11.28 & 4.21.E-04 & 1.00 & & & & & & & & \multirow{4}{*}{ Figure 4[} \\
\hline & $d s x$ all & 10 & 3.25 & 1.07.E-01 & 254.99 & -0.09 & 0.23 & -6.00 & 9.86 & 1.40.E-04 & 2.80.E-04 & $* * *$ & \\
\hline & dsx-like & 10 & 8.73 & 2.37.E-03 & 5.64 & -0.03 & 0.39 & -3.29 & 15.01 & 4.97.E-03 & 4.97.E-03 & ${ }^{* *}$ & \\
\hline & $d s x+d s x$-like & 9 & 2.82 & 1.42.E-01 & 336.55 & 0.00 & 0.00 & $-\ln f$ & $\mathrm{NaN}$ & 2.20.E-16 & 6.60.E-16 & 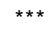 & \\
\hline \multirow{4}{*}{$\begin{array}{l}\text { vitellogenin-1 } \\
\text { expression level in } \\
\text { females }\end{array}$} & egfp & 8 & -2.67 & 6.34. E+00 & 1.00 & & & & & & & & \multirow{4}{*}{ Figure $4 \mathrm{E}$} \\
\hline & $d s \times$ all & 10 & -0.44 & 1.41. E+00 & 0.22 & 0.51 & 1.02 & 2.20 & 15.51 & 4.33.E-02 & 4.33.E-02 & * & \\
\hline & dsx-like & 7 & -0.29 & 1.22.E-00 & 0.19 & 0.70 & 1.08 & 4.55 & 10.89 & 8.51.E-04 & 2.56.E-03 & ** & \\
\hline & $d s x+d s x$-like & 8 & 0.90 & 5.40.E-01 & 0.09 & 0.58 & 1.10 & 3.00 & 8.82 & 1.52.E-02 & 3.05.E-02 & * & \\
\hline \multirow{4}{*}{$\begin{array}{l}\text { vitellogenin-2 } \\
\text { expression level in } \\
\text { females }\end{array}$} & egfp & 8 & 1.84 & 2.80.E-01 & 1.00 & & & & & & & & \multirow{4}{*}{ Figure $4 \mathrm{E}$} \\
\hline & $d s x$ all & 10 & 4.34 & 4.96.E-02 & 0.18 & 0.65 & 1.05 & 3.68 & 15.57 & 2.11.E-03 & 4.22.E-03 & $\star \star \star$ & \\
\hline & $d s x$-like & 7 & 5.24 & 2.65.E-02 & 0.09 & 0.83 & 1.06 & 8.45 & 12.94 & 1.27.E-06 & 3.80.E-06 & $* \star *$ & \\
\hline & $d s x+d s x$-like & 8 & 6.10 & 1.48.E-02 & 0.05 & 0.63 & 1.15 & 3.54 & 7.29 & 8.92.E-03 & 8.92.E-03 & ** & \\
\hline \multirow{4}{*}{$\begin{array}{l}\text { vitellogenin-3 } \\
\text { expression level in } \\
\text { females }\end{array}$} & egfp & 8 & -3.37 & 1.03. E+01 & 1.00 & & & & & & & & \multirow{4}{*}{ Figure $4 \mathrm{E}$} \\
\hline & $d s x$ all & 10 & -1.98 & 3.95. E+00 & 0.38 & 0.65 & 1.07 & 3.75 & 11.23 & 3.12.E-03 & 6.23.E-03 & $\star \star \star ~$ & \\
\hline & dsx-like & 8 & 0.84 & 7.82.E-01 & 0.08 & 0.81 & 1.06 & 7.56 & 12.60 & 4.98.E-06 & 1.49.E-05 & $* \star \star *$ & \\
\hline & $d s x+d s x$-like & 8 & 0.05 & 1.09. E+00 & 0.11 & 0.57 & 1.13 & 2.95 & 7.56 & 1.97.E-02 & 1.97.E-02 & * & \\
\hline
\end{tabular}

1101 The source data of this table can be obtained in the Table2-source data 1 file. 
1104 is an outlier or not is based on the $P$-value and is shown in the "outlier?" column.

\begin{tabular}{ccccccc}
\hline data & max/min & \multicolumn{1}{c}{ value } & \multicolumn{1}{c}{$\boldsymbol{G}$} & $\boldsymbol{U}$ & $\boldsymbol{P}$-value & outlier? \\
\hline \hline \multirow{2}{*}{ egfp } & $\max$ & 10.45 & 1.8587 & 0.65738 & $2.73 . \mathrm{E}-01$ & no \\
& $\min$ & 5.31 & 1.59672 & 0.74715 & $5.74 . \mathrm{E}-01$ & no \\
\hline \multirow{2}{*}{$d s x$} & $\max$ & 10.47 & 0.97 & 0.85 & $1.00 . \mathrm{E}+00$ & no \\
& $\min$ & 5.23 & 2.27 & 0.15688 & $5.14 . \mathrm{E}-03$ & yes \\
\hline \multirow{2}{*}{$d s x$-like } & $\max$ & 7.70 & 1.01 & 0.88 & $1.00 . \mathrm{E}+00$ & no \\
& $\min$ & 5.12 & 2.08 & 0.47 & $8.35 . \mathrm{E}-02$ & no \\
\hline \multirow{2}{*}{$\begin{array}{c}\text { reanalysis of } \\
d s x\end{array}$} & $\max$ & 10.47 & 1.52 & 0.55 & $3.52 . \mathrm{E}-01$ & no \\
& $\min$ & 8.44 & 1.42 & 0.61 & $4.70 . \mathrm{E}-01$ & no \\
\hline
\end{tabular}


Table 4. Results of generalized linear model of female traits. Significant levels are indicated by asterisks in significance column: $* P<0.05$,

$1108 * * P<0.01, * * * P<0.001$. n.s. means non-significance.

\begin{tabular}{|c|c|c|c|c|c|c|c|}
\hline objective variable & sample size (N) & explanatory variables & LR Chisq & Df & $P$-value & significance & Fig \# \\
\hline \multirow{4}{*}{ ovipositor length } & \multirow{4}{*}{$\begin{array}{l}\text { egfp: } 10, d s x \text { all: } 17 \\
d s x \text {-like: } 9, d s x+d s x- \\
\quad \text { like: } 12, \text { total: } 48\end{array}$} & dsx RNAi & 0.26 & 1 & 6.08.E-01 & n.s. & \multirow{4}{*}{ Figure $2 \mathrm{H}$} \\
\hline & & $d s x$-like RNAi & 0.58 & 1 & 4.47.E-01 & n.s. & \\
\hline & & prothoracic width & 297.00 & 1 & 2.00.E-16 & $* * *$ & \\
\hline & & $d s x$ RNAi:dsx-like RNAi & 2.67 & 1 & 1.02.E-01 & n.s. & \\
\hline \multirow{4}{*}{ ovipositor length } & \multirow{4}{*}{$\begin{array}{c}\text { egfp: } 8, d s x \text { all: } 8, \\
\text { dsx male-type: } 7, \\
\text { dsx female-type: } 13, \\
\text { total: } 36\end{array}$} & $d s x$ all RNAi & 1.29 & 1 & $2.56 . \mathrm{E}-01$ & n.s. & \multirow{4}{*}{$\begin{array}{c}\text { Figure } 2 \text {-figure } \\
\text { supplement } 3\end{array}$} \\
\hline & & dsx male-type RNAi & 1.29 & 1 & 2.56.E-01 & n.s. & \\
\hline & & dsx female-type RNAi & 0.42 & 1 & 5.18.E-01 & n.s. & \\
\hline & & prothoracic width & 146.52 & 1 & 2.00.E-16 & $* * *$ & \\
\hline \multirow{3}{*}{ prothoracic width } & \multirow{3}{*}{$\begin{array}{l}\text { egfp: } 10, d s x \text { all: } 17 \\
\text { dsx-like: } 9, d s x+d s x- \\
\quad \text { like: } 13, \text { total: } 49\end{array}$} & $d s x$ RNAi & 2.17 & 1 & 1.41.E-01 & n.s. & \multirow{3}{*}{$\begin{array}{c}\text { Figure 2-figure } \\
\text { supplement } 4\end{array}$} \\
\hline & & $d s x$-like RNAi & 1.96 & 1 & 1.61.E-01 & n.s. & \\
\hline & & $d s x$ RNAi:dsx-like RNAi & 2.16 & 1 & 1.41.E-01 & n.s. & \\
\hline \multirow{3}{*}{$\begin{array}{l}\text { previtellogenic } \\
\text { oocyte number }\end{array}$} & \multirow{3}{*}{$\begin{array}{c}\text { egfp: } 7, d s x \text { all: } 16, \\
\text { dsx-like: } 10, \\
\text { dsx+dsx-like: } 9, \text { total: } \\
42\end{array}$} & $d s x$ RNAi & 0.08 & 1 & 7.83.E-01 & n.s. & \multirow{3}{*}{ Figure 3D } \\
\hline & & $d s x$-like RNAi & 0.23 & 1 & 6.31.E-01 & n.s. & \\
\hline & & prothoracic width & 0.97 & 1 & 3.25.E-01 & n.s. & \\
\hline
\end{tabular}




\begin{tabular}{|c|c|c|c|c|c|c|c|}
\hline & & $d s x$ RNAi:dsx-like RNAi & 0.06 & 1 & 8.10.E-01 & n.s. & \\
\hline \multirow{4}{*}{$\begin{array}{l}\text { early vitellogenic } \\
\text { oocyte number }\end{array}$} & \multirow{4}{*}{$\begin{array}{c}\text { egfp: } 7, d s x \text { all: } 16, \\
\text { dsx-like: } 10, \\
\text { dsx+dsx-like: } 9, \text { total: } \\
42\end{array}$} & $d s x \mathrm{RNAi}$ & 0.11 & 1 & 7.45.E-01 & n.s. & \multirow{4}{*}{ Figure 3D } \\
\hline & & $d s x$-like RNAi & 0.08 & 1 & 7.77.E-01 & n.s. & \\
\hline & & prothoracic width & 3.50 & 1 & 6.14.E-02 & n.s. & \\
\hline & & dsx RNAi:dsx-like RNAi & 0.62 & 1 & 4.30.E-01 & n.s. & \\
\hline \multirow{4}{*}{$\begin{array}{l}\text { late vitellogenic } \\
\text { oocyte number }\end{array}$} & \multirow{4}{*}{$\begin{array}{c}\text { egfp: } 7, d s x \text { all: } 16, \\
\text { dsx-like: } 10, \\
\text { dsx+dsx-like: } 9, \text { total: } \\
42\end{array}$} & $d s x$ RNAi & 0.46 & 1 & 5.00.E-01 & n.s. & \multirow{4}{*}{ Figure 3D } \\
\hline & & dsx-like RNAi & 1.12 & 1 & 2.90.E-01 & n.s. & \\
\hline & & prothoracic width & 9.84 & 1 & 1.71.E-03 & $* *$ & \\
\hline & & $d s x$ RNAi:dsx-like RNAi & 2.16 & 1 & 1.42.E-01 & n.s. & \\
\hline \multirow{4}{*}{ oocyte size } & \multirow{4}{*}{$\begin{array}{l}\text { egfp: } 5, d s x \text { all: } 9, \\
\text { dsx-like: } 7, d s x+d s x- \\
\text { like: } 2, \text { total: } 23\end{array}$} & $d s x \mathrm{RNAi}$ & 0.1689 & 1 & 6.81.E-01 & n.s. & \multirow{4}{*}{$\begin{array}{c}\text { Figure3-figure } \\
\text { supplement } 3\end{array}$} \\
\hline & & $d s x$-like RNAi & 3.4291 & 1 & 6.41.E-02 & n.s. & \\
\hline & & prothoracic width & 4.273 & 1 & 3.87.E-02 & * & \\
\hline & & $d s x$ RNAi:dsx-like RNAi & 1.4509 & 1 & 2.23.E-01 & n.s. & \\
\hline
\end{tabular}

1109 The source data of this table can be obtained in the Table4-source data 1 file. 
1111 Table 5. Results of generalized linear model of male traits. $P$-values are indicated by asterisks in significance column: $* * P<0.01$. n.s. means

1112 non-significance.

\begin{tabular}{|c|c|c|c|c|c|c|c|}
\hline objective variable & sample size $(M)$ & explanatory variables & LR Chisq & Df & $P$-value & significance & Fig \# \\
\hline \multirow{4}{*}{ sperm number } & \multirow{4}{*}{$\begin{array}{c}\text { egfp: } 9 \\
\text { dsx all: } 6 \\
d s x \text {-like: } 10 \\
d s x+d s x \text {-like: } 4, \text { total: } 29\end{array}$} & $d s x \mathrm{RNAi}$ & 7.93 & 1 & 4.87.E-03 & ** & \multirow{4}{*}{ Figure $3 \mathrm{C}$} \\
\hline & & $d s x$-like RNAi & 2.06 & 1 & 1.51.E-01 & n.s. & \\
\hline & & prothoracic width & 8.68 & 1 & 3.21.E-03 & $* *$ & \\
\hline & & $d s x$ RNAi:dsx-like RNAi & 0.02 & 1 & 8.79.E-01 & n.s. & \\
\hline \multirow{3}{*}{ prothoracic width } & \multirow{3}{*}{$\begin{array}{l}\text { egfp: } 12, d s x \text { all: } 8, d s x- \\
\text { like: } 10, d s x+d s x \text {-like: } 6 \\
\text { total: } 36\end{array}$} & $d s \times \mathrm{RNAi}$ & 0.03 & 1 & 8.71.E-01 & n.s. & \multirow{3}{*}{$\begin{array}{l}\text { Figure } 2 \text {-figure } \\
\text { supplement } 4\end{array}$} \\
\hline & & $d s x$-like RNAi & 2.82 & 1 & 9.31.E-02 & n.s. & \\
\hline & & $d s x$ RNAi:dsx-like RNAi & 1.09 & 1 & 2.96.E-01 & n.s. & \\
\hline
\end{tabular}

1113 The source data of this table can be obtained in the Table5-source data 1 file. 
1115 Table 6. Primers' list used in this study.

\begin{tabular}{|c|c|c|c|c|c|c|}
\hline No. & expeiment & target & primer name & primer sequence ( $5^{\prime}$ to $\left.3^{\prime}\right)$ & length & note \\
\hline 1 & 5' RACE & doublesex $(d s x)$ & Tdom_dsx_RACE_01 & TCGCGTGACAAGGAAGAAGGCCCCGG & 26 & gene specific primer \\
\hline 2 & 5' RACE & $d s x$ & Tdom_dsx_RACE_02 & AGGCCCCGGAATTGAAGAAGCACCT & 25 & nested gene specific primer \\
\hline 3 & 5' RACE & doublesex-like (dsx-like) & Tdom_dsx-like_RACE_01 & CACTTTGAAAACGCAGGGCTGGATG & 25 & gene specific primer \\
\hline 4 & 5' RACE & dsx-like & Tdom_dsx-like_RACE_02 & GGGCTGGATGTTCGCTGTAGTTGAA & 25 & nested gene specific primer \\
\hline 5 & 3' RACE & $d s x$ & Tdom_dsx_RACE_03 & GCTTCTTCAATTCCGGGGCCTTCTTCC & 27 & gene specific primer \\
\hline 6 & 3' RACE & $d s x$ & Tdom_dsx_RACE_04 & TCAATTCCGGGGCCTTCTTCCTTGTCA & 27 & nested gene specific primer \\
\hline 7 & 3' RACE & dsx-like & Tdom_dsx-like_RACE_03 & AGACAGCAGCCAAATGACGTCAAGA & 25 & gene specific primer \\
\hline 8 & 3' RACE & dsx-like & Tdom_dsx-like_RACE_04 & ACAGCAGCCAAATGACGTCAAGAGA & 25 & nested gene specific primer \\
\hline 9 & RT-qPCR & ribosomal protein 49 (rp49) & Tdom_rp49_RT-qPCR_F & ACCCACCATAGTCAAGAAGCGGA & 23 & reference gene \\
\hline 10 & RT-qPCR & ribosomal protein 49 (rp49) & Tdom_rp49_RT-qPCR_R & AACTGTCCCTTAAACCGCCTTCG & 23 & reference gene \\
\hline 12 & RT-qPCR & $d s x$ male-specific region & Tdom_dsx_male_RT-qPCR_R & AGTGCCATGGATCGTAATTCTGCT & 24 & \\
\hline 13 & RT-qPCR & $d s x$ female-specific region & Tdom_dsx_female_RT-qPCR_F & CTACCGCTTGAAACATTGCCTTT & 23 & \\
\hline 14 & RT-qPCR & $d s x$ female-specific region & Tdom_dsx_female_RT-qPCR_R & TGCCCTGATTCATGCATTGA & 20 & \\
\hline 15 & RT-qPCR & $d s x$ common region & Tdom_dsx_RT-qPCR_F & ACCCAGCCATGCСТCСТАATGTA & 23 & \\
\hline 16 & RT-qPCR & $d s x$ common region & Tdom_dsx_RT-qPCR_R & CTTCGAGCGTCCTTCAGAACGAC & 23 & \\
\hline 17 & RT-qPCR & dsx-like & Tdom_dsx-like_RT-qPCR_F & ACGGGTTGTTGCTTTACATCTGT & 23 & \\
\hline 18 & RT-qPCR & dsx-like & Tdom_dsx-like_RT-qPCR_R & TCTCTTGACGTCATTTGGCTGCT & 23 & \\
\hline 19 & RT-qPCR & vitellogenin-1 & Tdom_vitellogenin-1_RT-qPCR_F & TGCTCCATTCAACAACCAGC & 20 & \\
\hline
\end{tabular}

60 


\begin{tabular}{|c|c|c|c|c|c|c|}
\hline 20 & RT-qPCR & vitellogenin-1 & Tdom_vitellogenin-1_RT-qPCR_R & AGCCCAGATGAACTTGACGA & 20 & \\
\hline 21 & RT-qPCR & vitellogenin-2 & Tdom_vitellogenin-2_RT-qPCR_F & CCAGTGATGGTGGCAATTCAGGA & 23 & \\
\hline 22 & RT-qPCR & vitellogenin-2 & Tdom_vitellogenin-2_RT-qPCR_R & TGTGGCTGTGACTGTCGTTTTGT & 23 & \\
\hline 23 & RT-qPCR & vitellogenin-3 & Tdom_vitellogenin-3_RT-qPCR_F & CACCAGCGATGTTGACGAGAAGA & 23 & \\
\hline 24 & RT-qPCR & vitellogenin-3 & Tdom_vitellogenin-3_RT-qPCR_R & GCTCAAACTCAGGCTCAAGTGGA & 23 & \\
\hline 25 & dsRNA & egfp & egfp_dsRNA_F & ATCATGGCCGACAAGCAGAA & 20 & control of RNAi assay \\
\hline 26 & dsRNA & egfp & egfp_dsRNA_R & AACTCCAGCAGGACCATGTG & 20 & control of RNAi assay \\
\hline 29 & dsRNA & $d s x$ common region & Tdom_dsx_dsRNA_F & CCAAGCCCAAGACGAAGC & 18 & \\
\hline 30 & dsRNA & $d s x$ common region & Tdom_dsx_dsRNA_R & CCGACTGTTACATTAGGAGGC & 21 & \\
\hline 31 & dsRNA & $d s x$ male-specific region & Tdom_dsx_male-type_dsRNA_F & GCAGAATTACGATCCATGGCAC & 22 & \\
\hline 32 & dsRNA & $d s x$ male-specific region & Tdom_dsx_male-type_dsRNA_R & CGTACTGGCCCTTTACATGGT & 21 & \\
\hline 33 & dsRNA & $d s x$ female-specific region & Tdom_dsx_female-type_dsRNA_F & TGCATGAATCAGGGCATTATTG & 22 & \\
\hline 35 & dsRNA & dsx-like & Tdom_dsx-like_dsRNA_F & CTCATGTGCAGTGATGTGGC & 20 & \\
\hline 36 & dsRNA & dsx-like & Tdom_dsx-like_dsRNA_R & TGCGTCAATGAACAGCGAAA & 20 & \\
\hline 37 & dsRNA & pCR4-TOPO vector & T7-pCR4-TOPO_F & taatacgactcactatagggAGACCACGTCCTGCAGGTTTAAACG & 45 & T7 flanked \\
\hline 38 & dsRNA & pCR4-TOPO vector & T7-pCR4-TOPO_R & taatacgactcactatagggAGACCACCGAATTGAATTTAGCGGC & 45 & T7 flanked \\
\hline
\end{tabular}

1116 


\section{Figure Supplements}

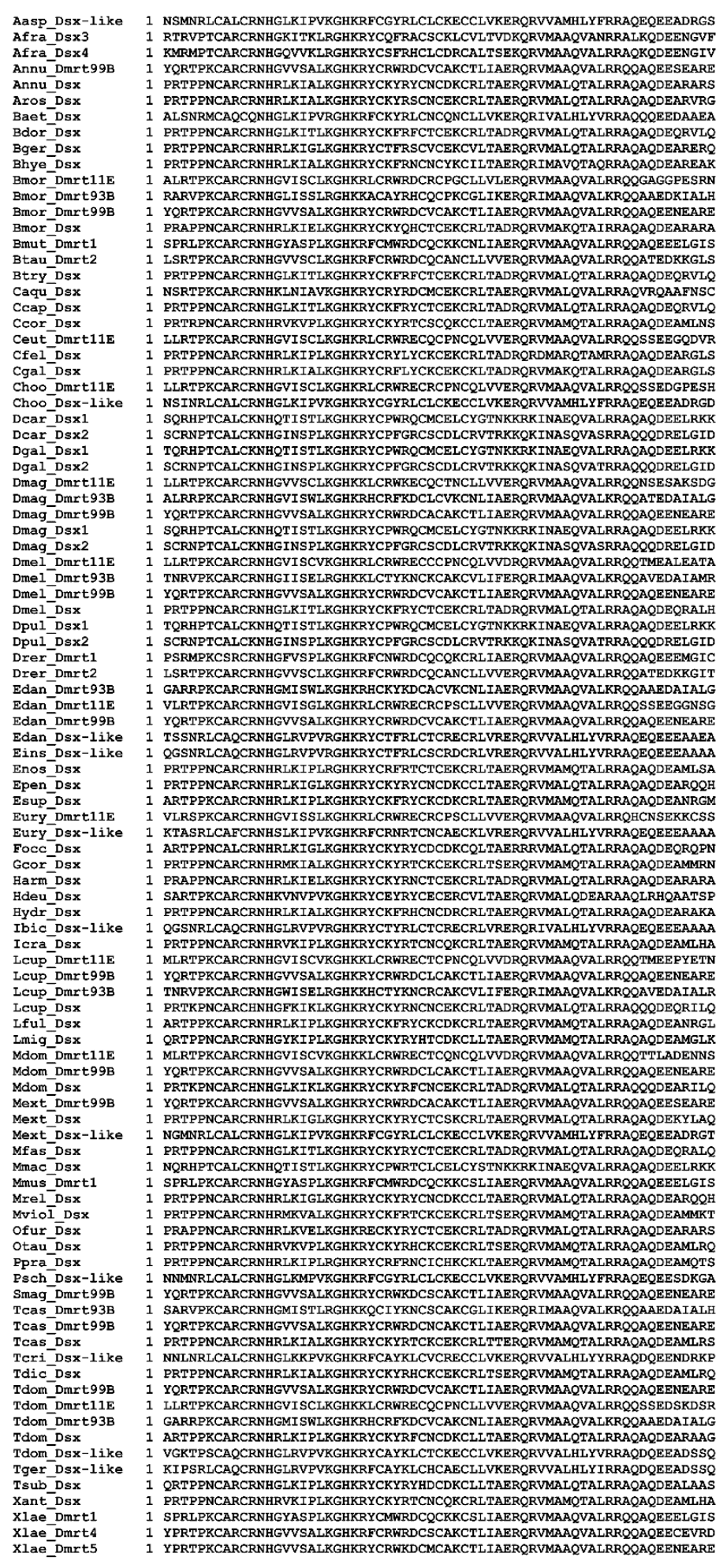

1118 Figure 1-figure supplement 1. Multiple sequence alignment of DM domain of 1119 DMRT family proteins for molecular phylogenetic analysis. The 65 amino acids of 97 1120 DMRT proteins were used for the molecular phylogenetic analysis. 


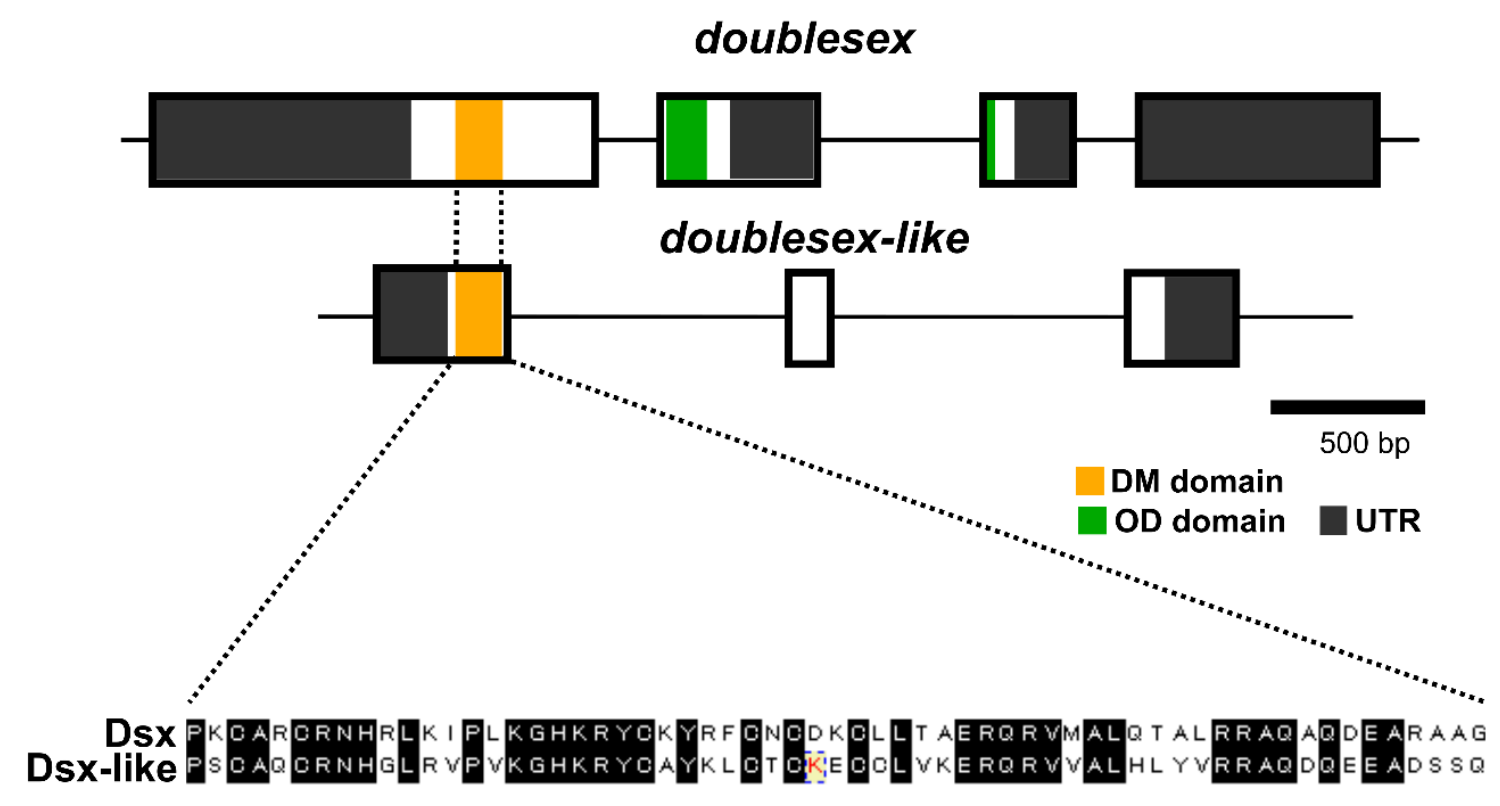

Figure 1-figure supplement 2. Comparison of DM domain sequences between Dsx and Dsx-like. The upper figures show the gene structures of $d s x$ and $d s x$-like, and the lower one is the result of the multiple sequence alignment of the DM domain in Dsx and Dsx-like of Thermobia domestica. The black-highlighted sequences are shared in both proteins. 

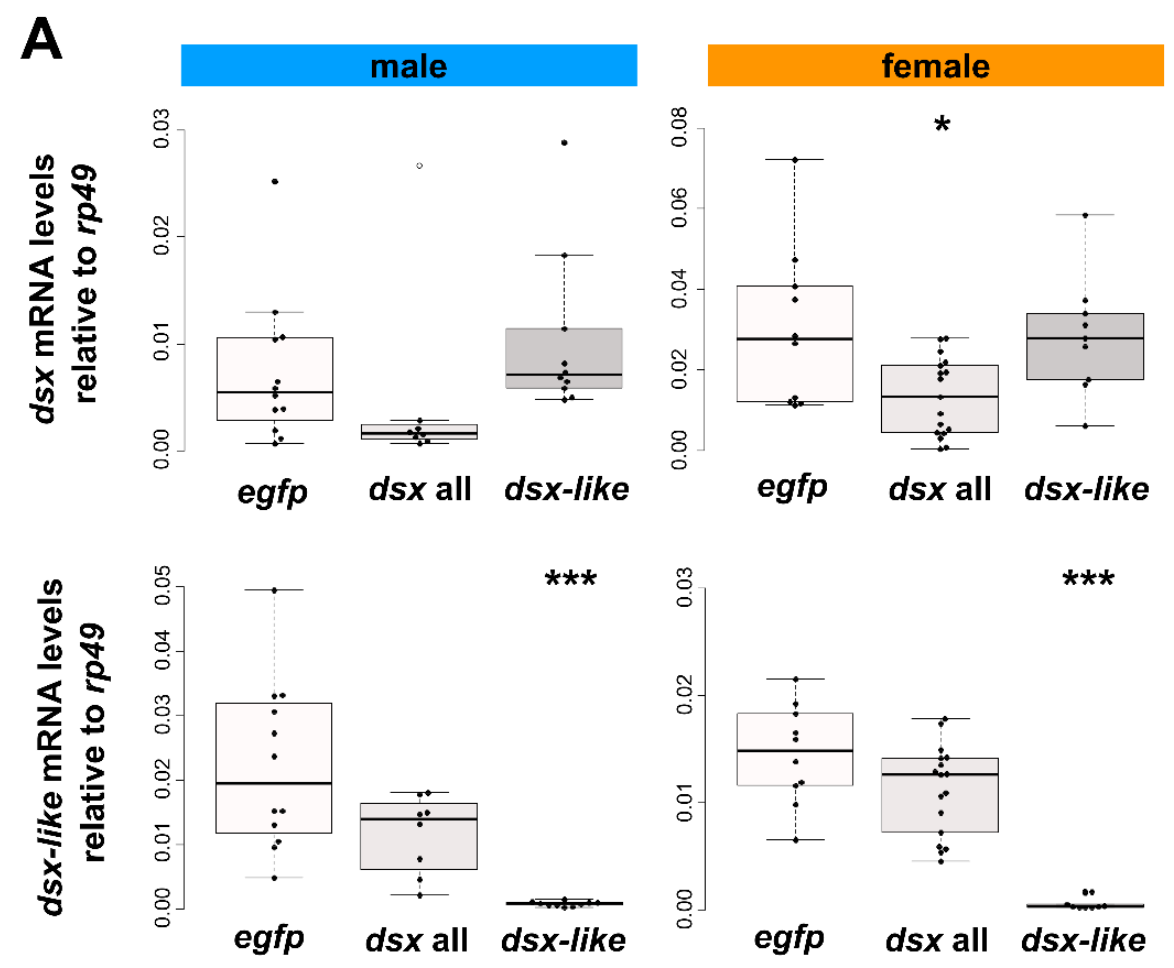

Figure 1-figure supplement 3. Expression of $d s x$ and $d s x$-like mRNA in nymphal RNAi individuals. (A) results of RT-qPCR assay. The expression profiles of $d s x$ and $d s x$-like mRNA were analyzed by RT-qPCR assay and are indicated by their expression level relative to the expression of a reference gene (ribosomal protein 49). The upper graphs are the expression of $d s x$ mRNA and the lower ones are that of $d s x$ like mRNA. The left column is the result in males and the right one is that in females. (B) the expression level of $d s x$ mRNA in the nymphal RNAi males after excluding an outlier. To test the outlier, the Smirnov-Grubbs' test was performed. Results of the Smirnov-Grubbs' test are shown in Table 3. Results of the Brunner-Munzel test are indicated by asterisks: $* P<0.05 ; * * P<0.01 ; * * * P<0.001$ and is also described in Table 2. $P>0.05$ is not shown. Each plot is an individual. White plot is the outlier. Sample size are listed in Table 2. 


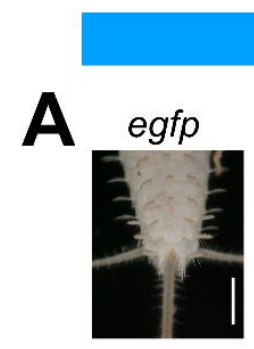

\section{male}

$d s x$

male-type female-type
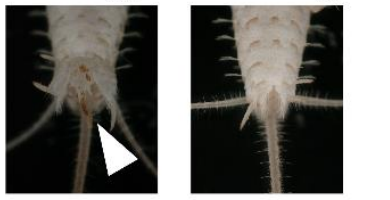

C
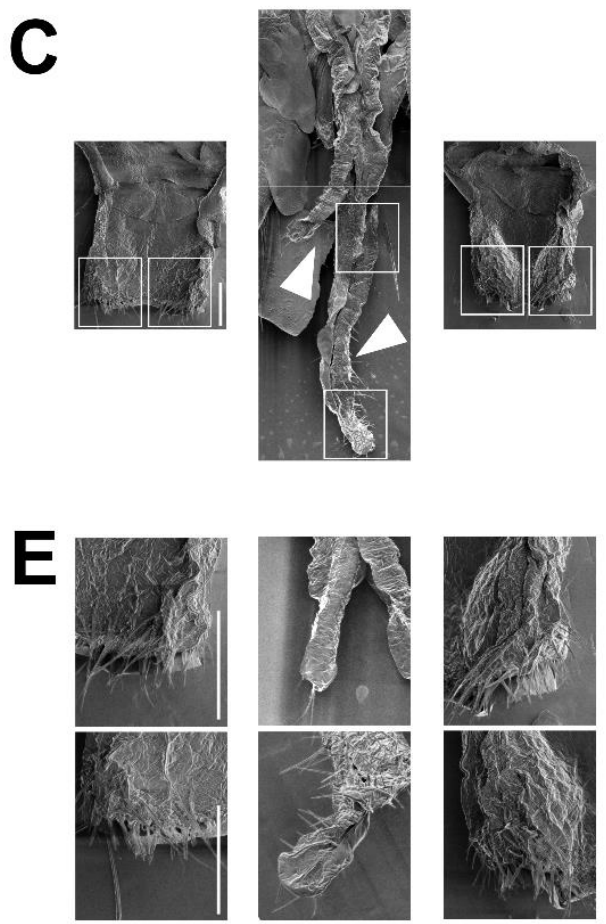
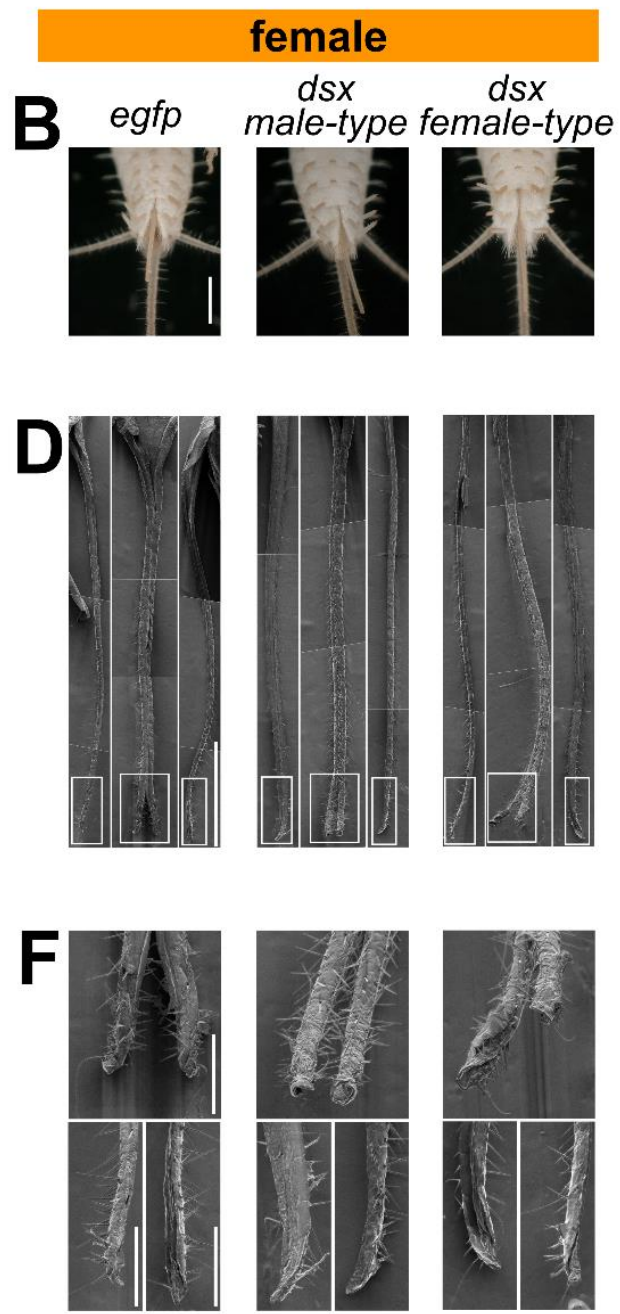

Figure 2-figure supplement 1. External genital organs of nymphal RNAi individuals. (A) The penis in ventral view of $d s x$ male or female-type RNAi males. (B) The ovipositor in ventral view of $d s x$ male or female-type RNAi females. (C) SEM images of the male penis or the ovipositor-like organ. White frames are the areas shown in (E). (D) SEM images of the female ovipositor. Each image is separated into three parts. The left and right image is each lobe of the valvula I. The middle image is the valvula II. White frames are the areas showed in (F). (E) Higher magnification SEM images of the male genital organ in (C). Each image shows the higher magnification view of the area enclosed by the white frame in (C). (F) Higher magnification SEM images of the ovipositor. Each image shows the higher magnification view of the area enclosed by the white frame in $(D)$. The arrowheads show the ovipositor-like organ in the $d s x$ male-type RNAi male. Scales: $1000 \mu \mathrm{m}$ (A, $\mathrm{B}$, and $\mathrm{D}), 100 \mu \mathrm{m}(\mathrm{C}, \mathrm{E}$, and F). 


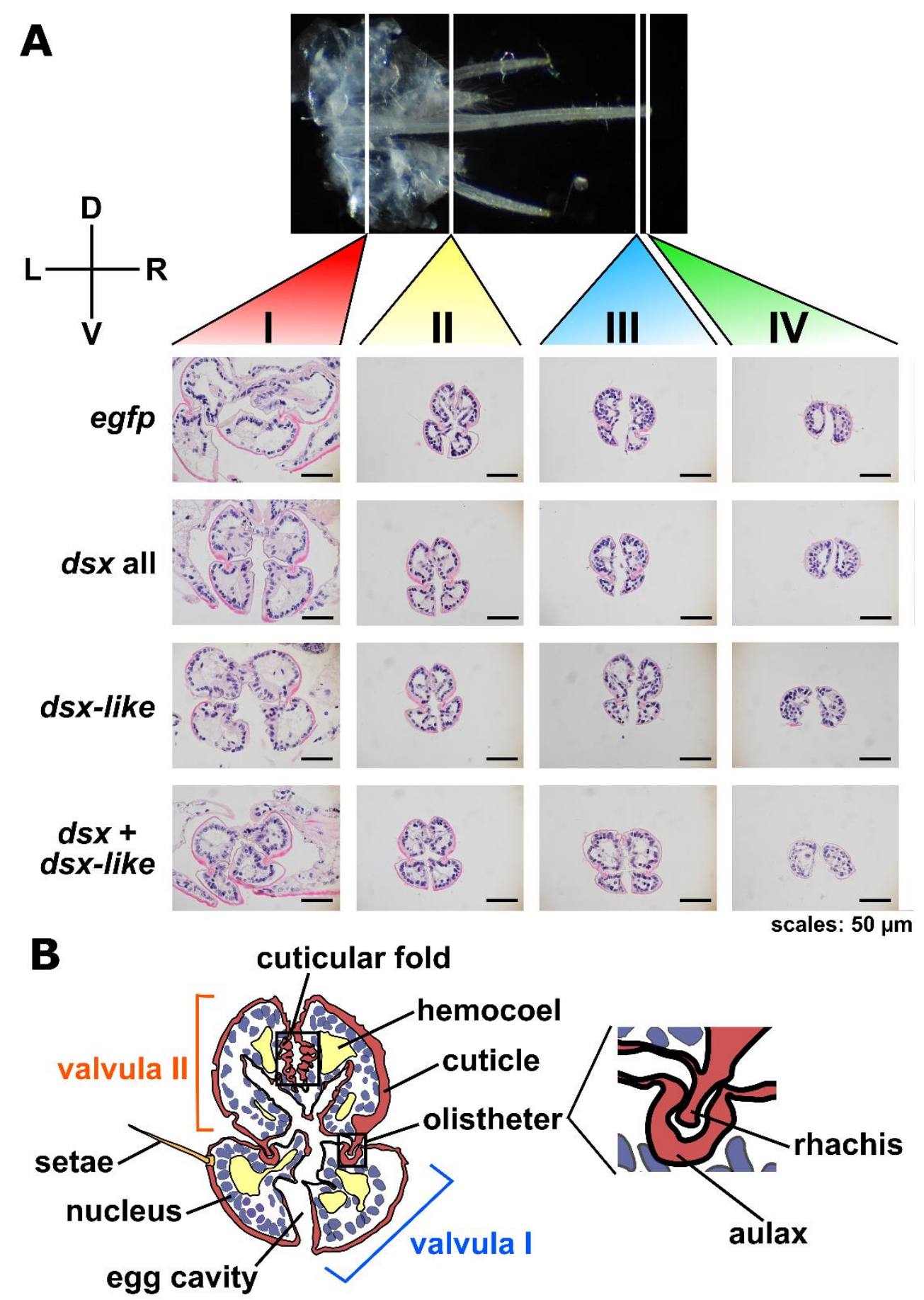

Figure 2-figure supplement 2. Morphology of ovipositor in nymphal RNAi the ovipositor in four parts: I (proximal part), II (middle part), III (distal part), and IV (most-distal part). D, dorsal; L, left; R, right; V, ventral. Scales: $50 \mu \mathrm{m}$. (B) Schematic figure of the ovipositor morphology. This figure is based on the cross-section of the part II in the control female. 


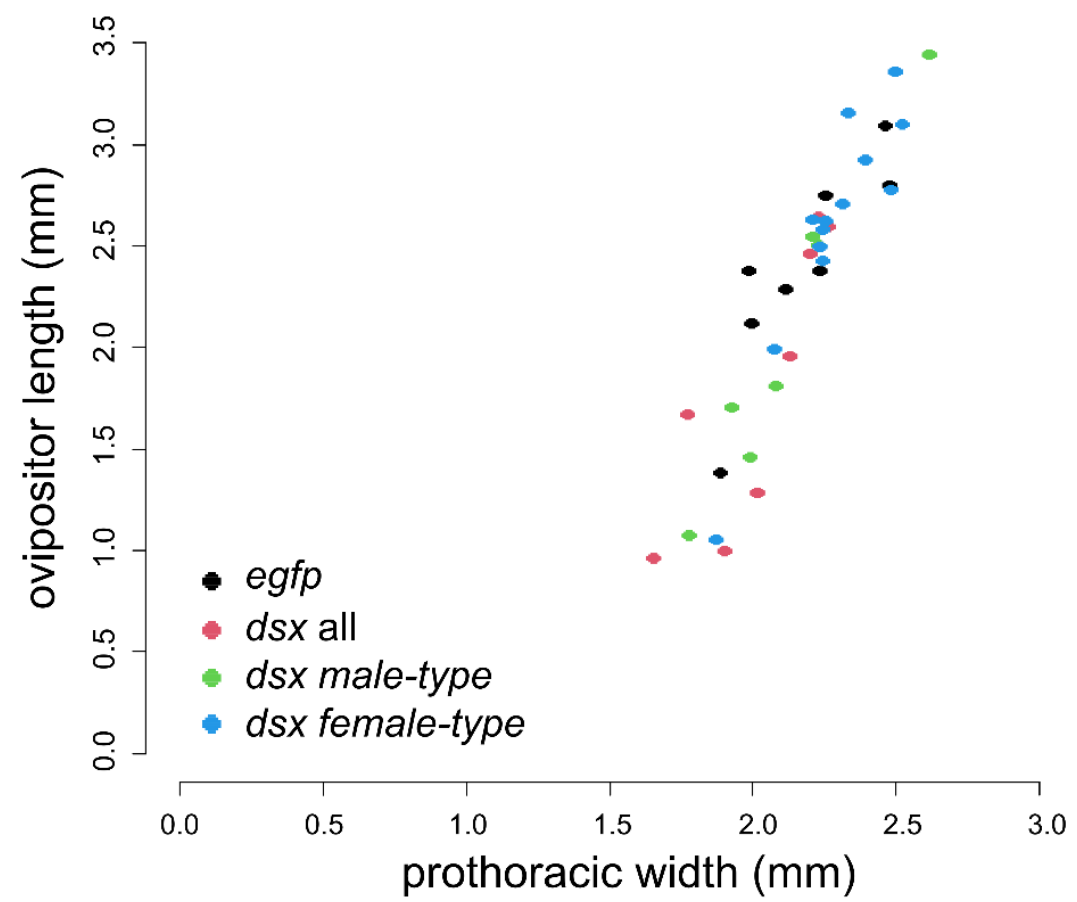

1162 Figure 2-figure supplement 3. Ovipositor length of $d s x$ isoforms RNAi individuals.

1163 The ovipositor length of $d s x$ all, male-, and female-type RNAi females is plotted

1164 against the prothoracic width. The results of the statistical analysis are described in

1165 Table 4. 


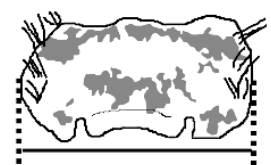

\section{prothoracic width}
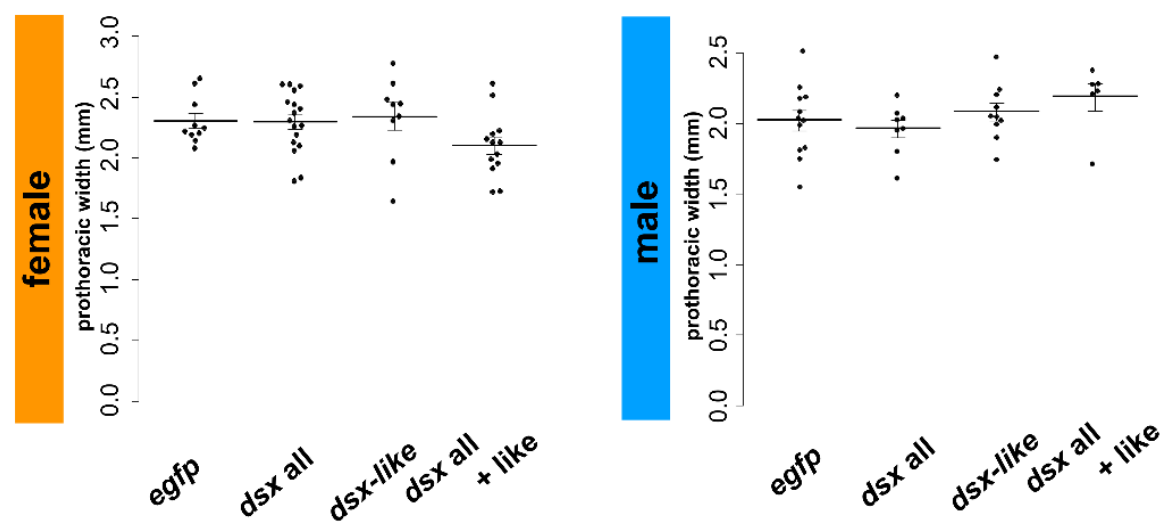

1168 Figure 2-figure supplement 4. Prothoracic width of nymphal RNAi individuals. The left and right graphs show the female and the male size, respectively. Data shows mean \pm Stand ard Error (SE). The results of the statistical analysis are described in

1171 Tables 4 (female) and 5 (male). 


\section{A}

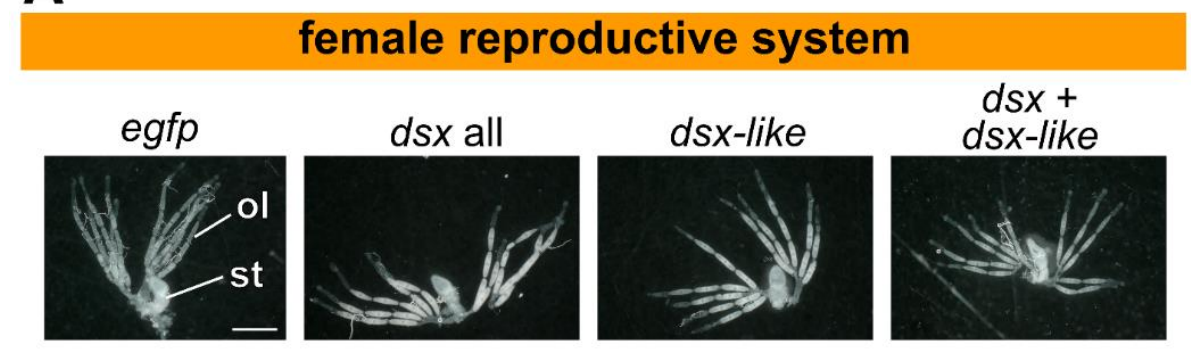

B

\section{male reproductive system}
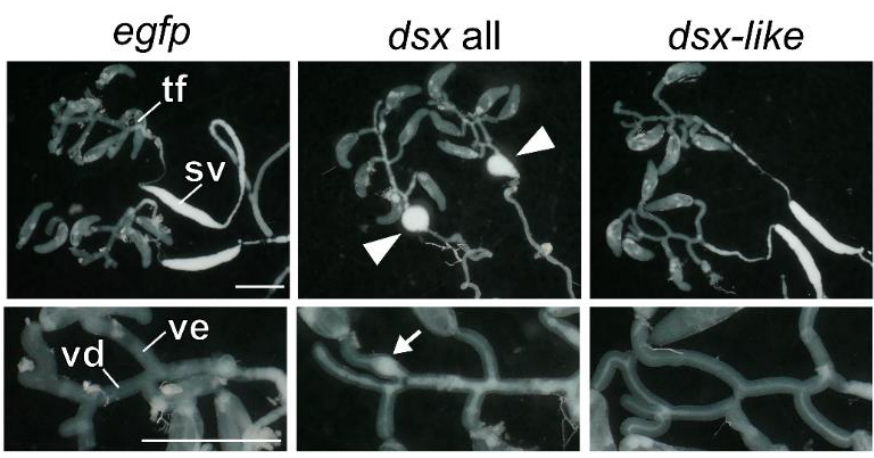

$d s x+$

dsx-like

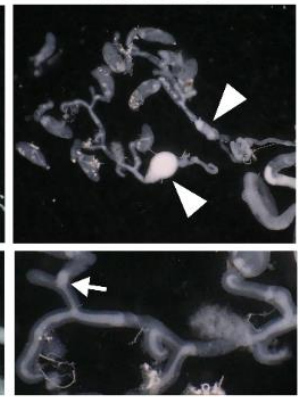

Figure 3-figure supplement 1. Gonads of nymphal RNAi individuals. (A) female reproductive system. ol, ovariole; st, spermatheca. (B) male reproductive system. The upper photos are the are from the testicular follicle to the seminal vesicle. The lower ones are the high-magnification image of the vas efferens and the vas deferens. The arrowheads show the round-shape seminal vesicle. The arrows indicate sperm clots in the vas efferens. sv, seminal vesicle; tf, testicular follicle; ve, vas efferens; vd, vas deferens. Scales: $1 \mathrm{~mm}$. 


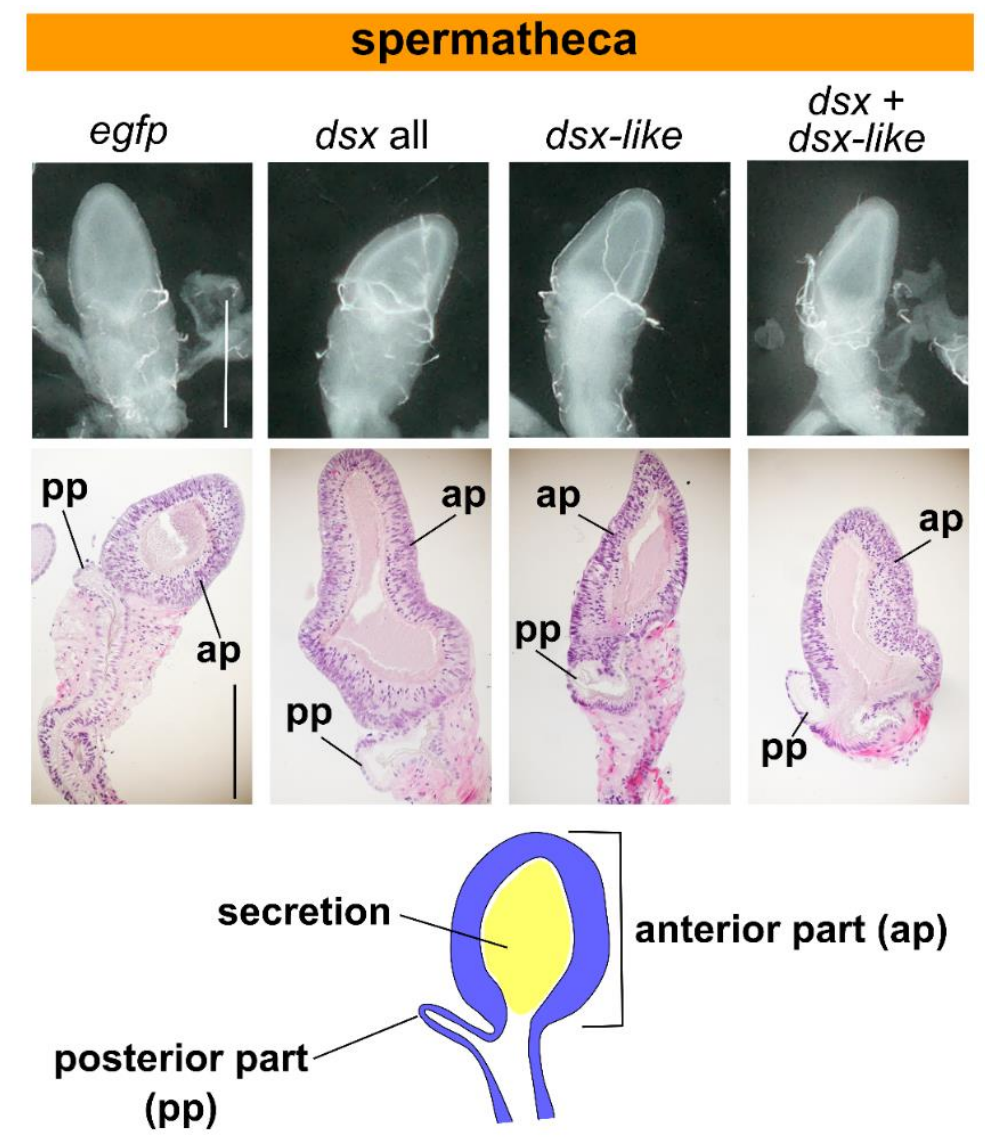

Figure 3-figure supplement 2. Morphology of spermatheca in nymphal RNAi individuals. The upper photos show the light microscopic images of the spermatheca. The middle ones are paraffin sections of the spermatheca. The lower one is the schematic image of the spermatheca of $T$. domestica. Scales: $500 \mu \mathrm{m}$. 


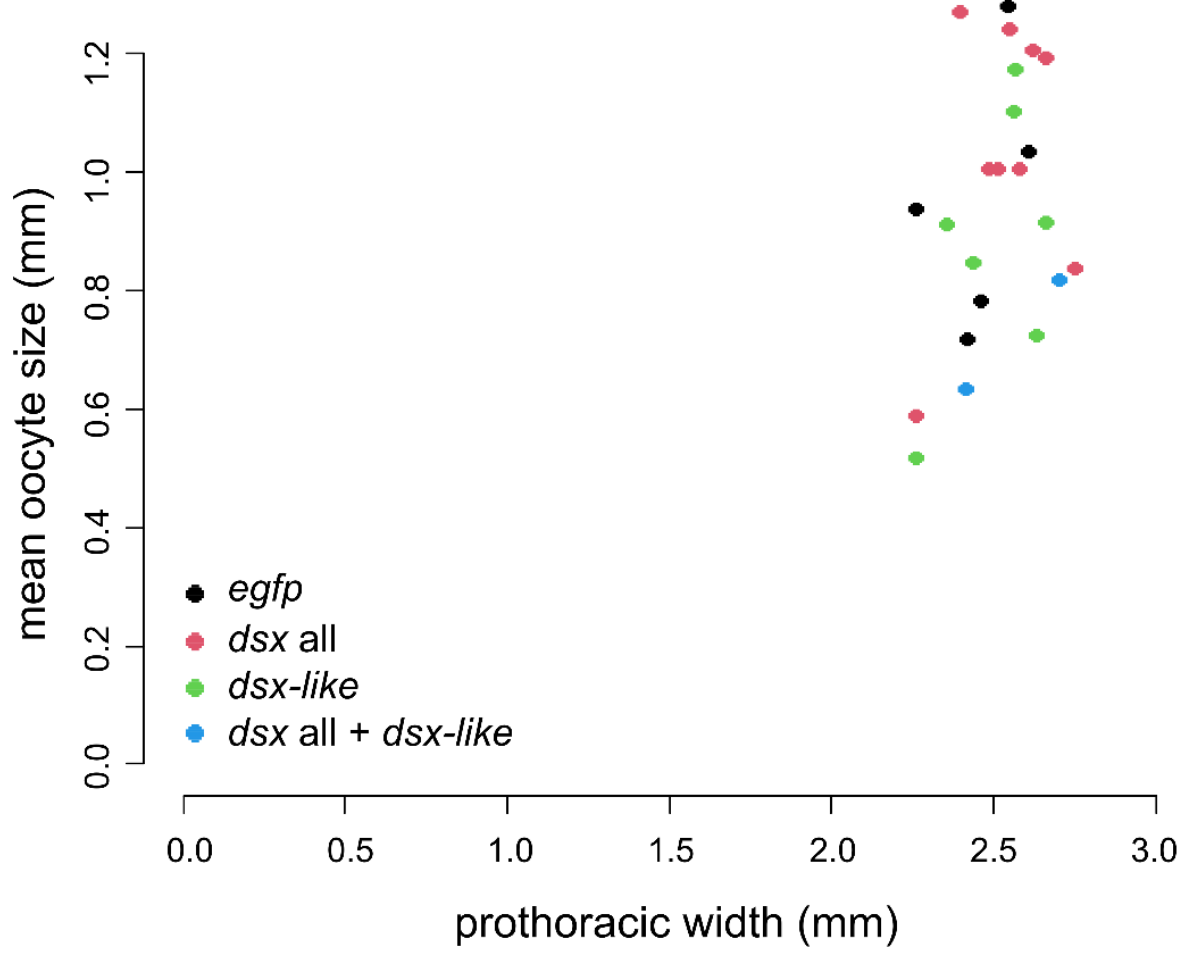

1187 Figure 3-figure supplement 3. Oocyte size of $d s x$ isoforms RNAi individuals. The 1188 oocyte size of $d s x$ all, $d s x$-like, and both $d s x$ and $d s x$-like RNAi females is plotted 1189 against the prothoracic width. The results of the statistical analysis are described in 1190 Table 4. 
bioRxiv preprint doi: https://doi.org/10.1101/2021.08.02.454784; this version posted August 5, 2021. The copyright holder for this preprint (which was not certified by peer review) is the author/funder, who has granted bioRxiv a license to display the preprint in perpetuity. It is made available under aCC-BY 4.0 International license.
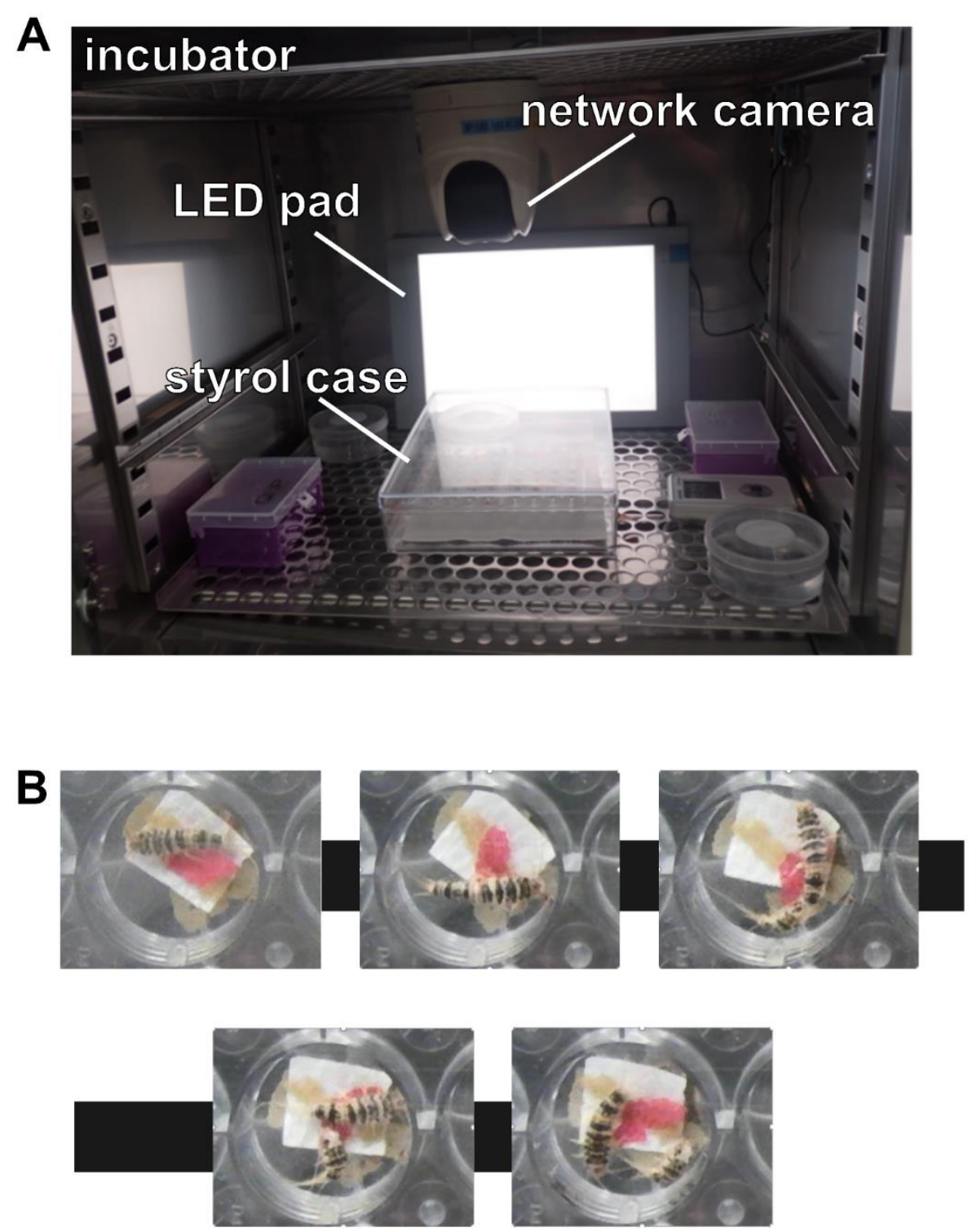

1192 Figure 4-figure supplement 1. Time-lapse imaging system. (A) A photo of the timelapse imaging system used to observe the molt of $T$. domestica. (B) The images during the molt. 


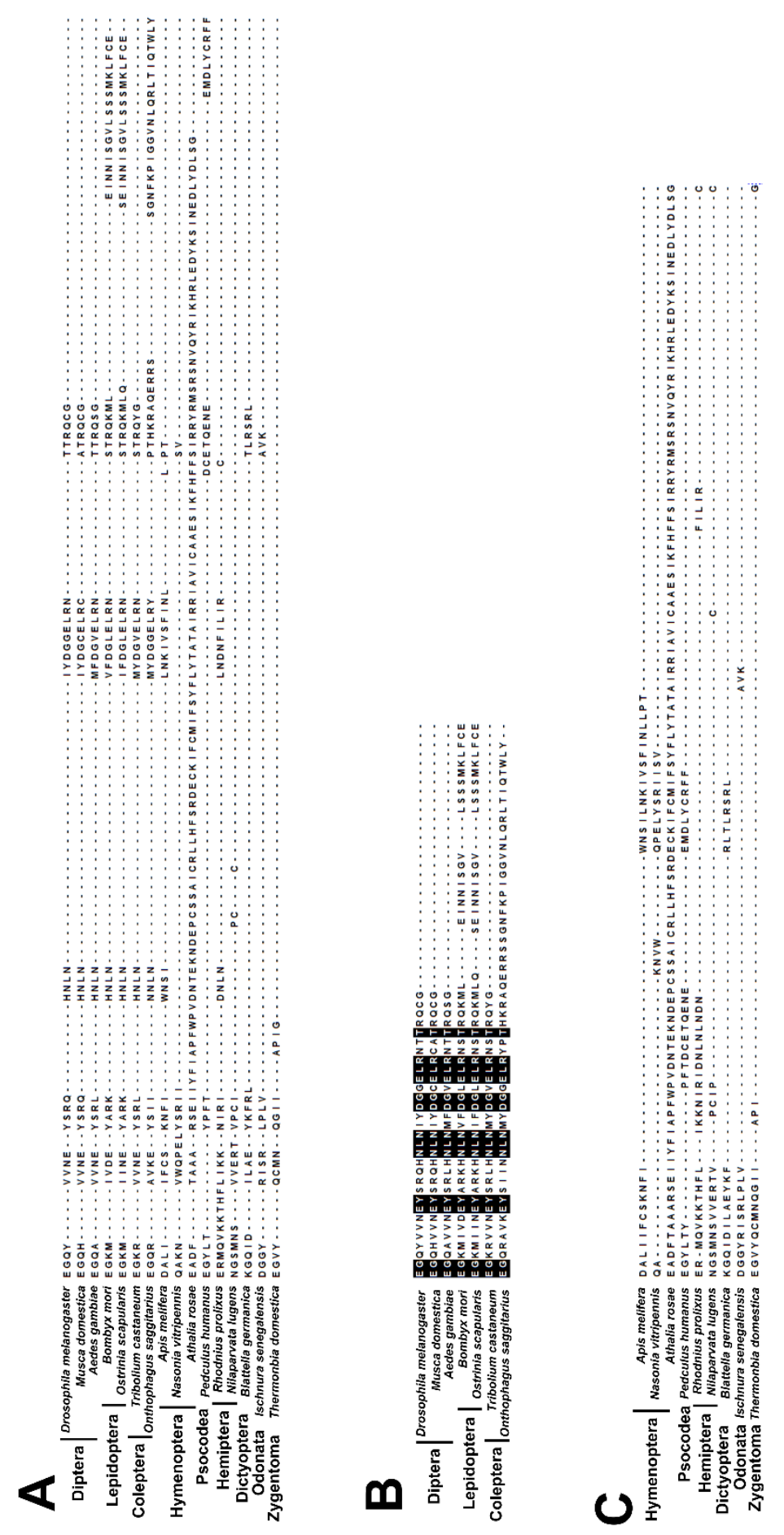

1196 Figure 5-figure supplement 1. Multiple sequence alignments of insect Dsx female1197 specific region. (A) Comparison of the female-specific region of insect Dsx among 1198 the all taxa. (B) Comparison of the female-specific region of insect Dsx among the 1199 taxa with the dual-functionality. (C) Comparison of the female-specific region of 1200 insect Dsx among the taxa with the single-functionality. The black-highlighted 1201 sequences are shared in all given taxa. 


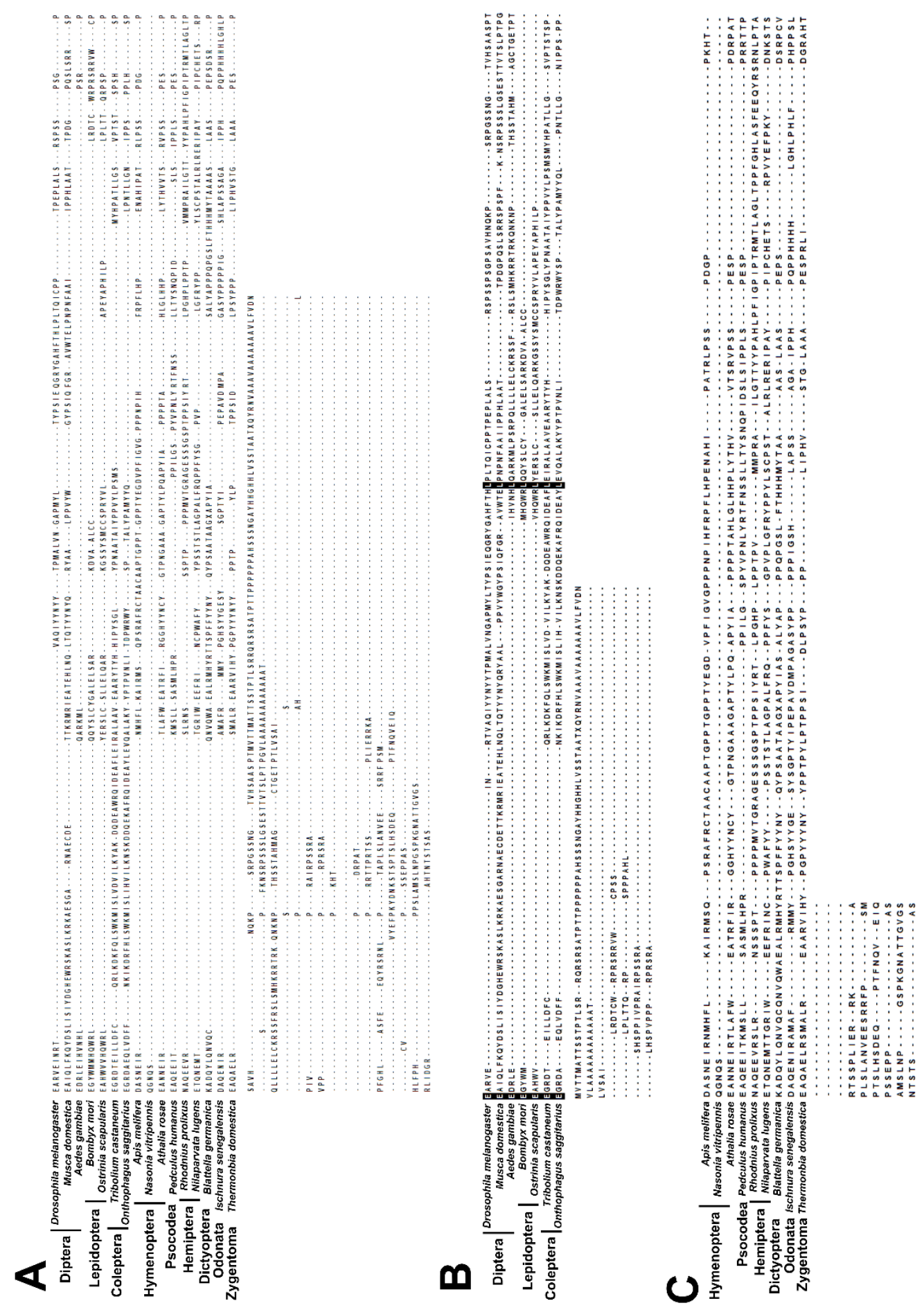

Figure 5-figure supplement 2. Multiple sequence alignments of insect Dsx malespecific region. (A) Comparison of the male-specific region of insect Dsx among the all taxa. (B) Comparison of the male-specific region of insect Dsx among the taxa with the dual-functionality. (C) Comparison of the male-specific region of insect Dsx among the taxa with the single-functionality. The black-highlighted sequences are shared in all given taxa. 
bioRxiv preprint doi: $h t t p s: / / d o i . o r g / 10.1101 / 2021.08 .02 .454784$ : this version posted Auqust 5, 2021. The copvriaht holder for this preprint (which was not certified by peer review) is the author/funder, who has granted bioRxiv a license to display the preprint in perpetuity. It is made available under aCC-BY 4.0 International license. 